Aus der Abteilung Humangenetik

(Prof. Dr. med. Dr. h. c. W. Engel)

im Zentrum Hygiene und Humangenetik

der Medizinischen Fakultät der Universität Göttingen

\title{
Zur molekularen und funktionellen \\ Charakterisierung von Mutationen in den SPG4- und SPG7- Genen
}

\author{
Inaugural-Dissertation \\ zur Erlangung des Doktorgrades \\ der Medizinischen Fakultät \\ der Georg-August-Universität zu Göttingen
}

\author{
vorgelegt von \\ Moneef Shoukier \\ aus Souieda, Syrien
}

Göttingen 2010 
Dekan

I. Berichterstatter

II. Berichterstatterin
: Prof. Dr. med. C. Frömmel

: Prof. Dr. med. Dr. h. c. W. Engel

: PD Dr. med. Dr. rer. nat. Zirn

Tag der mündlichen Prüfung $\quad$ : 28.02.2011 
Inhaltsverzeichnis

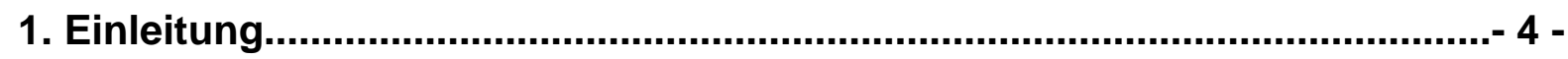

1.1 Die hereditären spastischen Paraplegien.......................................... 4 -

1.2 Genetik der hereditären spastischen Paraplegien................................. 5 -

1.3 Zur Funktion der HSP-Proteine...........................................................-10-

1.4 Gegenstand der kumulativen Schrift................................................-12-

2. Material und Methoden...............................................................................-13 -

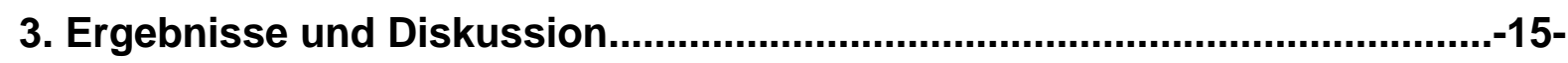

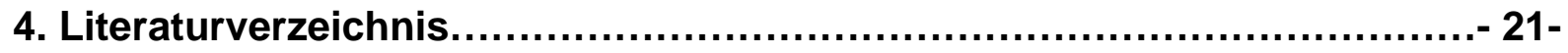

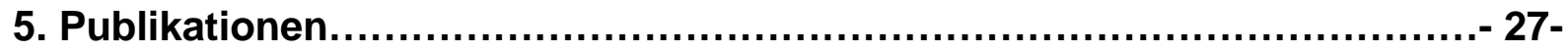

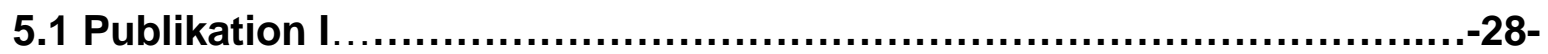

5.2 Publikation II.................................................................

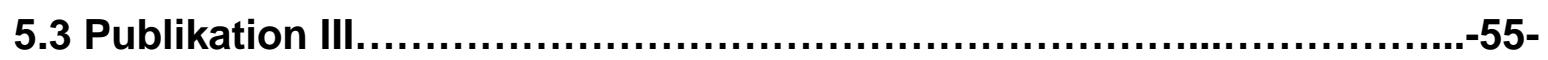

6. Publikationsliste....................................................................67- 


\section{Einleitung}

\subsection{Die hereditären spastischen Paraplegien}

Die hereditären spastischen Paraplegien (HSP), auch hereditäre spastische Spinalparalysen oder spastische Paraplegien (SPG) genannt, stellen eine Gruppe heterogener neurodegenerativer Erkrankungen dar. Sie sind durch eine progrediente spastische Paralyse der unteren Extremitäten gekennzeichnet. Klinisch unterscheidet man zwei Formen der Erkrankung: 1. bei der reinen HSP (rHSP) beschränken sich die Symptome auf die unteren Extremitäten. Die Patienten leiden an einer spastischen, ataktischen Gangstörung. Zudem weisen diese Patienten eine spastische Tonuserhöhung der Muskulatur, gesteigerte Muskeleigenreflexe und ein positives Babinskizeichen auf. Häufig findet man neben den motorischen Auffälligkeiten eine Störung der Pallästhesie sowie eine Urge-Inkontinenz; 2. bei der komplizierten Form der HSP (kHSP) können zusätzliche neurologische Symptome, wie z.B. eine mentale Retardierung, Optikusatrophie, Sprachstörung, Ataxie, Dysphagie, Störungen der Merkfähigkeit und Retinopathie hinzukommen (Sauter et al. 2002, McDermott et al. 2006).

Soweit es Angaben zur Prävalenz der HSP gibt, schwanken diese zwischen 7.4 /100000 Einwohner in Norwegen (Erichsen et al. 2009) und 12/100000 Einwohner in Italien (Filla et al. 1992). Für Deutschland liegen bislang keine Zahlen vor.

Neuropathologisch finden sich bei der rHSP eine axonale Degeneration der Pyramidenbahn und des Fasciculus gracilis. Zusätzlich können zerebrale Auffälligkeiten auftreten, u.a. eine Atrophie des Corpus callosum sowie periventrikuläre Veränderungen der weißen Substanz (Somasundaram et al. 2007), oder ein hypoplastisches Cerebellum sowie Atrophien der Basalganglien bei kHSP (Elleuch et al. 2006).

Die Diagnose basiert auf dem charakteristischen progredient verlaufenden klinischen Bild und der möglichen positiven Familienanamnese. Differenzialdiagnostisch 
können folgende Erkrankungen in Erwägung gezogen werden: Zerebralparesen, eine Kompression des Rückenmarks durch Tumoren oder ein Bandscheibenprolaps, Autoimmunerkrankungen wie Multiple Sklerose (MS), metabolische Störungen wie

z.B. Vitamin-B12-Mangel, Vitamin-E-Mangel, A-Beta-Lipoproteinämien und Leukodystrophien bzw. deren spinale Formen, die Adrenomyeloneuropathien, toxische Myelopathien wie Neurocassavaismus und Neurolathyrismus (Ludolph 2006) und Infektionskrankheiten wie die HTLV-1-assoziierte tropische spastische Paraparese und Aids. Andere neurodegenerative Erkrankungen wie die Spinozerebellären Ataxien (SCA) oder die Amyotrophe Lateralsklerose (ALS) sollten differenzialdiagnostisch bedacht werden. Für die Stellung der Diagnose einer HSP sind daher folgende Zusatzuntersuchungen von Bedeutung: ein MRT des Kopfes und der Wirbelsäule zum Ausschluss spinaler Tumoren und zervikaler Myelopathien, die elektrophysiologischen Untersuchungen des peripheren Nervensystems wie somatosensibel evozierte Potenziale (SEP) des Nervus medianus und des Nervus tibialis, biochemische Laboruntersuchungen, vor allem die Bestimmung der sehr langkettigen Fettsäuren zum Ausschluss einer Adrenoleukodystrophie. Bezüglich der Differenzialdiagnose gegenüber der MS und der Infektionskrankheiten ist in manchen Fällen auch eine Liquorpunktion notwendig (Sauter et al. 2002; Finsterer 2003). Da das Krankheitsbild der HSP sich derart komplex und vielfältig präsentiert, können letztendlich nur die molekulargenetische Diagnostik und der Nachweis einer Mutation in einem entsprechenden HSP-Gen die Diagnose sichern.

Eine kausale Therapie der HSP ist nicht möglich. Die Behandlung erfolgt daher symptomatisch. Zu den nichtmedikamentösen Therapiemöglichkeiten zählen z.B. Bewegungs- und Physiotherapie, Hilfsmittelversorgung und die Beratung. Eine medikamentöse antispastische Therapie (z.B. Baclofen, Tizanidin, Dantrolen, Memantine oder Tetrazepam) kann Funktionsverbesserungen bewirken. Der Erfolg dieser Therapie kann allerdings durch die Zunahme der Spastik bei den Patienten auch unbefriedigend verlaufen (Winner et al. 2004).

\subsection{Genetik der hereditären spastischen Paraplegien}

Die hereditären spastischen Paraplegien sind eine sehr heterogene Gruppe von Erkrankungen mit autosomal dominantem (70-80\%), autosomal rezessivem (15- 
$20 \%$ ) oder X-chromosomal rezessivem Erbgang. Bis zum jetzigen Zeitpunkt konnten über 40 Loci bzw. 17 Gene für die Erkrankung identifiziert worden.

Für die autosomal-dominant vererbte HSP (ADHSP) konnten bisher 10 Gene identifiziert werden, und 18 verschiedene Loci sind bekannt (Tab. 1).

Tabelle 1: Die autosomal-dominanten Formen der HSP (ADHSP)

\begin{tabular}{|c|c|c|c|c|c|c|}
\hline HSP-Typ & Locus & Gen & Protein & Phänotyp & $\begin{array}{c}\text { Mittleres } \\
\text { Erkrankungs- } \\
\text { alter }\end{array}$ & Referenz \\
\hline SPG3 & $\begin{array}{c}14 q 11- \\
q 21\end{array}$ & SPG3A* & Atlastin & $\begin{array}{c}\text { rHSP } \\
\text { und } \\
\text { kHSP }\end{array}$ & 〜 Jahre & $\begin{array}{c}\text { (Hazan } \\
\text { et al.1993) }\end{array}$ \\
\hline SPG4 & $2 p 22-21$ & $\begin{array}{l}\text { SPAST* } \\
(S P G 4)\end{array}$ & Spastin & $\begin{array}{c}\text { rHSP } \\
\text { und } \\
\text { kHSP }\end{array}$ & 〜29 Jahre & $\begin{array}{c}\text { (Hazan } \\
\text { et al. 1994) }\end{array}$ \\
\hline SPG6 & $15 q 11$ & $\begin{array}{l}\text { NIPA1* } \\
\text { (SPG6) }\end{array}$ & $\begin{array}{c}\text { Non- } \\
\text { imprinted in } \\
\text { PraderWilli/ } \\
\text { Angelman } \\
\text { syndrome } \\
\text { region } \\
\text { protein1 }\end{array}$ & $\mathrm{rHSP}$ & 〜22 Jahre & $\begin{array}{c}\text { (Fink et al. } \\
\text { 1995) }\end{array}$ \\
\hline SPG8 & $8 p 24.13$ & $\begin{array}{c}\text { KIAA0196* } \\
\text { (SPG8) }\end{array}$ & Strumpellin & $\mathrm{rHSP}$ & 〜37 Jahre & $\begin{array}{l}\text { (Valdmanis } \\
\text { et al. 2007) }\end{array}$ \\
\hline SPG9 & $\begin{array}{c}10 q 23.3- \\
q 24.2\end{array}$ & Unbekannt & Unbekannt & kHSP & $\begin{array}{c}\text { Kinds- } \\
\text { bis zum } \\
\text { Erwachsenenalter }\end{array}$ & $\begin{array}{l}\text { (Lo Nigro } \\
\text { et al. 2000) }\end{array}$ \\
\hline SPG10 & $12 q 13$ & $\begin{array}{c}\text { KIF5A } \\
\text { (SPG10) }\end{array}$ & $\begin{array}{l}\text { Kinesin } \\
\text { heavy } \\
\text { chain } \\
\text { isoform } \\
5 \mathrm{~A}\end{array}$ & $\begin{array}{l}\text { RHSP } \\
\text { und } \\
\text { kHSP }\end{array}$ & $\begin{array}{c}\text { Normalerweise in } \\
\text { Kindsalter }\end{array}$ & $\begin{array}{c}\text { (Reid et al. } \\
\text { 2002) }\end{array}$ \\
\hline SPG12 & $19 q 13$ & Unbekannt & Unbekannt & rHSP & ７ Jahre & $\begin{array}{l}\text { (Reid et al. } \\
\text { 2000) }\end{array}$ \\
\hline
\end{tabular}




\begin{tabular}{|c|c|c|c|c|c|c|}
\hline SPG13 & $\begin{array}{c}2 q 24- \\
\text { q34 }\end{array}$ & $\begin{array}{l}\text { HSP60 } \\
\text { (SPG13) }\end{array}$ & Chaperonin & rHSP & 39 Jahre & $\begin{array}{c}\text { (Hansen } \\
\text { et al.2002) }\end{array}$ \\
\hline $\begin{array}{l}\text { SPG17 } \\
\text { (Silver- } \\
\text { Syndrom) }\end{array}$ & $\begin{array}{c}\text { 11q12- } \\
\text { q14 }\end{array}$ & $\begin{array}{c}\text { BSCL2 } \\
\text { (SPG17) }\end{array}$ & Seipin & kHSP & $\begin{array}{c}\text { Jugend- } \\
\text { bis zum } \\
\text { Erwachsenenalter }\end{array}$ & $\begin{array}{c}\text { (Warner } \\
\text { et al. 2004) }\end{array}$ \\
\hline SPG19 & $\begin{array}{l}\text { 9q33- } \\
\text { q34 }\end{array}$ & Unbekannt & Unbekannt & rHSP & 36-55 Jahre & $\begin{array}{c}\text { (Valente } \\
\text { et al. 2002) }\end{array}$ \\
\hline SPG29 & $\begin{array}{c}\text { 1p31.1- } \\
21.1\end{array}$ & Unbekannt & Unbekannt & kHSP & 15 Jahre & $\begin{array}{l}\text { (Orlacchio } \\
\text { et al. 2005) }\end{array}$ \\
\hline SPG31 & $2 \mathrm{p} 11.2$ & $\begin{array}{l}\text { REEP1* } \\
\text { (SPG31) }\end{array}$ & $\begin{array}{l}\text { Receptor } \\
\text { expression } \\
\text { enhancing } \\
\text { protein } 1\end{array}$ & $\begin{array}{l}\mathrm{rHSP} \\
\text { und } \\
\mathrm{kHSP}\end{array}$ & $\begin{array}{l}\text { Kinds- bis zum } \\
\text { Jugendalter }\end{array}$ & $\begin{array}{l}\text { (Zuchner } \\
\text { et al. 2006) }\end{array}$ \\
\hline SPG33 & $10 q 24.2$ & $\begin{array}{l}\text { ZFYVE27 } \\
\text { (SPG33) }\end{array}$ & $\begin{array}{l}\text { Zinc finger, } \\
\text { FYVE } \\
\text { domain } \\
\text { containing } \\
27\end{array}$ & rHSP & Erwachsenenalter & $\begin{array}{l}\text { (Mannan } \\
\text { et al. 2006) }\end{array}$ \\
\hline SPG37 & $\begin{array}{c}\text { 8p21.1- } \\
q 13.3\end{array}$ & Unbekannt & Unbekannt & $\mathrm{rHSP}$ & 8 - 60 Jahre & $\begin{array}{c}\text { (Hanein } \\
\text { et al. 2007) }\end{array}$ \\
\hline $\begin{array}{l}\text { SPG38 } \\
\text { (Silver- } \\
\text { Syndrom) }\end{array}$ & $\begin{array}{l}4 p 16- \\
\text { p15 }\end{array}$ & Unbekannt & Unbekannt & kHSP & Unbekannt & $\begin{array}{l}\text { (Orlacchio } \\
\text { et al. 2008) }\end{array}$ \\
\hline SPG42 & $3 q 25.31$ & $\begin{array}{l}\text { SLC33A1 } \\
\text { (SPG42) }\end{array}$ & $\begin{array}{c}\text { Acetyl-CoA } \\
\text { transporter } \\
1\end{array}$ & $\mathrm{rHSP}$ & $4-40$ & $\begin{array}{c}\text { (Lin et al. } \\
2008)\end{array}$ \\
\hline
\end{tabular}

In den mit * gekennzeichneten Genen sind Mutationen mit einer Häufigkeit von mindestens $>3 \%$ bei Patienten mit einer ADHSP detektiert worden.

Für die autosomal-rezessiv vererbten HSPs (ARHSP) konnten bisher 8 Gene identifiziert werden, und 19 verschiedene Loci sind bekannt (Tab. 2). 
Tabelle 2: Die autosomal-rezessiven Formen der HSP (ARHSP)

\begin{tabular}{|c|c|c|c|c|c|c|}
\hline SPG-Typ & Locus & Gen & Protein & Phänotyp & $\begin{array}{c}\text { Mittleres } \\
\text { Erkrankungs- } \\
\text { alter }\end{array}$ & Referenz \\
\hline SPG5 & $8 q 12-q 13$ & $\begin{array}{l}\text { CYP7B1* } \\
\text { (SPG5) }\end{array}$ & $\begin{array}{c}\text { Cytochrome } \\
\text { P450, } \\
\text { family } 7, \\
\text { subfamilyB, } \\
\text { polypeptide1 }\end{array}$ & $\mathrm{rHSP}$ & 1-20 Jahre & $\begin{array}{l}\text { (Hentati et al. } \\
\text { 1994) }\end{array}$ \\
\hline SPG7 & $16 q 24.3$ & $S P G 7^{*}$ & Paraplegin & $\begin{array}{c}\text { rHSP } \\
\text { und } \\
\text { kHSP }\end{array}$ & 25-42 Jahre & $\begin{array}{c}\text { (Elleuch et al. } \\
\text { 2006) }\end{array}$ \\
\hline SPG11 & $15 q 21.1$ & SPG11* & Spatacsin & $\begin{array}{l}\text { rHSP } \\
\text { und } \\
\text { kHSP }\end{array}$ & $\begin{array}{c}\text { Jugend- } \\
\text { Bis } \\
\text { zum } \\
\text { Erwachsenenalter }\end{array}$ & $\begin{array}{c}\text { (Somasundaram } \\
\text { et al. 2007) }\end{array}$ \\
\hline SPG14 & $\begin{array}{c}(3 q 27- \\
q 28)\end{array}$ & Unbekannt & Unbekannt & kHSP & 30 Jahre & $\begin{array}{c}\text { (Vazza } \\
\text { et al. 2000) }\end{array}$ \\
\hline $\begin{array}{c}\text { SPG15 } \\
\text { (Kjellin- } \\
\text { Syndrom) }\end{array}$ & $\begin{array}{c}\text { 14q23.3- } \\
\text { q24.2 }\end{array}$ & $\begin{array}{l}\text { ZFYVE26* } \\
\text { (SPG15) }\end{array}$ & Spastizin & kHSP & 13-23 Jahre & $\begin{array}{l}\text { (Hughes } \\
\text { et al. 2001) }\end{array}$ \\
\hline $\begin{array}{l}\text { SPG20 } \\
\text { (Troyer- } \\
\text { Syndrom) }\end{array}$ & $13 q 12$ & SPG20* & Spartin & kHSP & Kindsalter & $\begin{array}{l}\text { (Proukakis } \\
\text { et al. 2004) }\end{array}$ \\
\hline SPG21 & $19 q 13$ & SPG21 & Maspardin & kHSP & Kindsalter & $\begin{array}{l}\text { (Simpson } \\
\text { et al. 2003) }\end{array}$ \\
\hline SPG23 & 1q24-q32 & Unbekannt & Unbekannt & kHSP & Kindsalter & $\begin{array}{c}\text { (Blumen } \\
\text { et al. 2003) }\end{array}$ \\
\hline SPG24 & $13 q 14$ & Unbekannt & Unbekannt & rHSP & Kindsalter & $\begin{array}{l}\text { (Hodgkinson } \\
\text { et al. 2002) }\end{array}$ \\
\hline SPG25 & $6 q 23-q 24$ & Unbekannt & Unbekannt & kHSP & Kindsalter & $\begin{array}{c}\text { (Zortea } \\
\text { et al. 2002) }\end{array}$ \\
\hline SPG26 & $\begin{array}{c}\text { 12p11.1- } \\
\text { q14 }\end{array}$ & Unbekannt & Unbekannt & kHSP & 7-8Jahre & $\begin{array}{l}\text { (Wilkinson } \\
\text { et al. 2005) }\end{array}$ \\
\hline SPG27 & $\begin{array}{c}\text { 10q22.1- } \\
q 24.1\end{array}$ & Unbekannt & Unbekannt & $\mathrm{rHSP}$ & Erwachsenenalter & $\begin{array}{c}\text { (Meijer } \\
\text { et al. 2004) }\end{array}$ \\
\hline SPG28 & $\begin{array}{c}14 q 21.3- \\
q 22.3\end{array}$ & Unbekannt & Unbekannt & kHSP & Kindsalter & $\begin{array}{l}\text { (Bouslam } \\
\text { et al. 2005) }\end{array}$ \\
\hline SPG30 & $2 q 37$ & Unbekannt & Unbekannt & kHSP & Jugendalter & $\begin{array}{c}\text { (Klebe } \\
\text { et al. 2006) }\end{array}$ \\
\hline
\end{tabular}




\begin{tabular}{|c|c|c|c|c|c|c|}
\hline SPG32 & $\begin{array}{c}14 \mathrm{q} 12- \\
\mathrm{q} 21\end{array}$ & Unbekannt & Unbekannt & kHSP & Unbekannt & $\begin{array}{c}\text { (Stevanin } \\
\text { et al. 2007) }\end{array}$ \\
\hline SPG35 & $\begin{array}{c}16 \mathrm{q} 21- \\
\mathrm{q} 23.1\end{array}$ & $\begin{array}{c}\text { FA2H } \\
\text { (SPG35) }\end{array}$ & $\begin{array}{c}\text { Fatty acid2- } \\
\text { hydroxylase }\end{array}$ & kHSP & Kindsalter & $\begin{array}{c}\text { (Dick } \\
\text { et al. 2010) }\end{array}$ \\
\hline SPG39 & $19 \mathrm{p} 13.3$ & $\begin{array}{c}\text { PNPLA6 } \\
\text { (SPG39) }\end{array}$ & $\begin{array}{c}\text { Neuropathy } \\
\text { target } \\
\text { esterase }\end{array}$ & kHSP & Kindsalter & $\begin{array}{c}\text { (Rainier } \\
\text { et al. 2008) }\end{array}$ \\
\hline SPG45 & $\begin{array}{c}10 \mathrm{q} 24.3- \\
\mathrm{q} 25.1\end{array}$ & Unbekannt & Unbekannt & kHSP & Kindsalter & $\begin{array}{c}\text { (Dursun } \\
\text { et al. 2009) }\end{array}$ \\
\hline SPG46 & $\begin{array}{c}9 \mathrm{p} 21.2- \\
\mathrm{q} 21.12\end{array}$ & Unbekannt & Unbekannt & kHSP & 2-10 Jahre & $\begin{array}{c}\text { (Boukhris } \\
\text { et al. 2010) }\end{array}$ \\
\hline
\end{tabular}

In den mit * gekennzeichneten Genen sind Mutationen mit einer Häufigkeit von mindestens $>3 \%$ bei Patienten mit einer ARHSP detektiert worden.

Die X-chromosomal rezessiv vererbte HSP ist selten und tritt häufig als kHSP Form auf. Bislang konnten 2 X-chromosomal lokalisierte Gene identifiziert werden, und 4 verschiedene Loci auf dem X-Chromosom sind bekannt (Tab. 3).

Tabelle 3: Die X-chromosomal vererbte Form der HSP

\begin{tabular}{|c|c|c|c|c|c|c|}
\hline SPG-Typ & Locus & Gen & Protein & Phänotyp & $\begin{array}{c}\text { Mittleres } \\
\text { Erkrankungs- } \\
\text { alter }\end{array}$ & Referenz \\
\hline $\begin{array}{c}\text { SPG1 } \\
\text { (MASA- } \\
\text { Syndrom) }\end{array}$ & Xq28 & L1CAM & $\begin{array}{c}\text { Neural } \\
\text { cell } \\
\text { adhesion } \\
\text { molecule L1 } \\
\text { (L1-CAM) }\end{array}$ & kHSP & Kongenital & $\begin{array}{c}\text { (Jouet } \\
\text { et al. 1994) }\end{array}$ \\
\hline SPG2 & Xq22 & PLP1 & $\begin{array}{l}\text { Proteolipo- } \\
\text { protein }\end{array}$ & kHSP & Kindsalter & $\begin{array}{l}\text { (Kobayashi } \\
\text { et al. 1994) }\end{array}$ \\
\hline SPG16 & $\mathrm{Xq11.2}$ & Unbekannt & Unbekannt & $\begin{array}{l}\text { rHSP und } \\
\text { kHSP }\end{array}$ & $\begin{array}{c}\text { Jugend- } \\
\text { bis } \\
\text { zum } \\
\text { Erwachsenenalter }\end{array}$ & $\begin{array}{l}\text { (Tamagaki } \\
\text { et al. 2000) }\end{array}$ \\
\hline SPG34 & Xq22.2 & Unbekannt & Unbekannt & rHSP & 12 -25 Jahre & $\begin{array}{l}\text { (Macedo- } \\
\text { Souza } \\
\text { et al. 2008) }\end{array}$ \\
\hline
\end{tabular}


Neumutationen in den HSP-Genen wurden beschrieben, aber es gibt derzeit keine Angaben über deren tatsächliche Häufigkeit (Abel et al. 2004, Rainier et al. 2006 und Depienne et al. 2007).

\subsection{Zur Funktion der HSP-Proteine}

Die HSP-Proteine lassen sich entsprechend ihren Funktionen in fünf Gruppen unterteilen (Abb. 1):

1) In nukleär kodierte mitochondriale Proteine wie z.B. Paraplegin (SPG7), Chaperonin (SPG13), Spartin (SPG20), Spatacsin (SPG11) und REEP1 (SPG31). Diese Proteine können proteolytisch oder Chaperon-ähnlich (assemblieren Proteinkomponenten und aktivieren Atmungskettenkomplexe) in den Mitochondrien wirken (Dion et al. 2009).

2) In Proteine, die für den axonalen Transport und für die axonale ZytoskelettStruktur mitverantwortlich sind, z.B. Spastin (SPG4), kinesin heavy chain isoform 5A (SPG10) und Spartin (SPG20). Mutationen im SPG4-Gen stellen die häufigste Ursache einer ADHSP dar (15-40\%). Spastin gehört zu der Familie der AAAProteasen (ATPases associated with diverse cellular activities). Die Interaktion des Spastin-Proteins mit Mikrotubuli konnte belegt werden. Diese Interaktion beeinflusst sowohl den axonalen Fluss als auch den intrazellulären Transport in den Neuronen. Die Funktionsstörung der Mikrotubuli bei langen Projektionsaxonen wurde als Ursache der degenerativen Veränderungen bei HSP4 postuliert (Solowska et al. 2010).

3) In Proteine, die für die Funktion des Golgi-Apparats wichtig sind. Mutationen im SPG3A-Gen (kodiert für Atlastin) oder im SPG21-Gen (kodiert für Maspardin) u.a. führen zu einer Funktionseinschränkung des Golgi-Apparats (Dion et al. 2009). Atlastin gehört zur Superfamilie der großen GTPasen. Mutationen im SPG3A-Gen sind die zweithäufigste Ursache (ca. 8-10\%) der ADHSP (Rainier et al. 2006). Der größte Teil solcher Mutationen ist in oder um die GTPase-Domäne gebündelt und führt zum Verlust der katalytischen Aktivität des Atlastins (Botzolakis et al. 2010). 
4) In Myelinproteine wie z.B. Proteolipoprotein (SPG2), welches für die Reifung und Kompaktierung des Myelins verantwortlich ist. Mutationen im SPG2-Gen sind hauptsächlich für die X-chromosomal rezessiv vererbte Pelizaeus-MerzbacherKrankheit verantwortlich, die durch eine ausgeprägte Demyelinisierung im ZNS und eine Störung der Oligodendrozytenfunktion charakterisiert ist. Die HSP vom Typ 2 (SPG2) stellt eine mildere Form dieser Erkrankung dar, und es wird hier eine Störung des axonalen Transports vermutet (Edgar et al. 2004).

5) In Proteine, die eine zentrale Rolle bei der embryonalen Entwicklung des Kortikospinalen Traktes spielen, z.B. das Zelladhäsionsmolekül L1 (L1-CAM oder SPG1). L1-CAM ist ein transmembranäres Glykoprotein der Immunglobulin-Familie und reguliert die Zellmigration und Zelladhäsion, Neuritenfaszikulation und Myelinisierung während der embryonalen Entwicklung. Eine Reihe von Erkrankungen wie z.B. Hydrozephalus, MASA-Syndrom (Mentale Retardierung, Aphasie, schlurfender Gang, adduzierte Daumen), die X-chromosomal rezessiv vererbte HSP vom Typ 1 und mentale Retardierung wird durch Mutationen im SPG1-Gen hervorgerufen (Nagaraj et al. 2009).

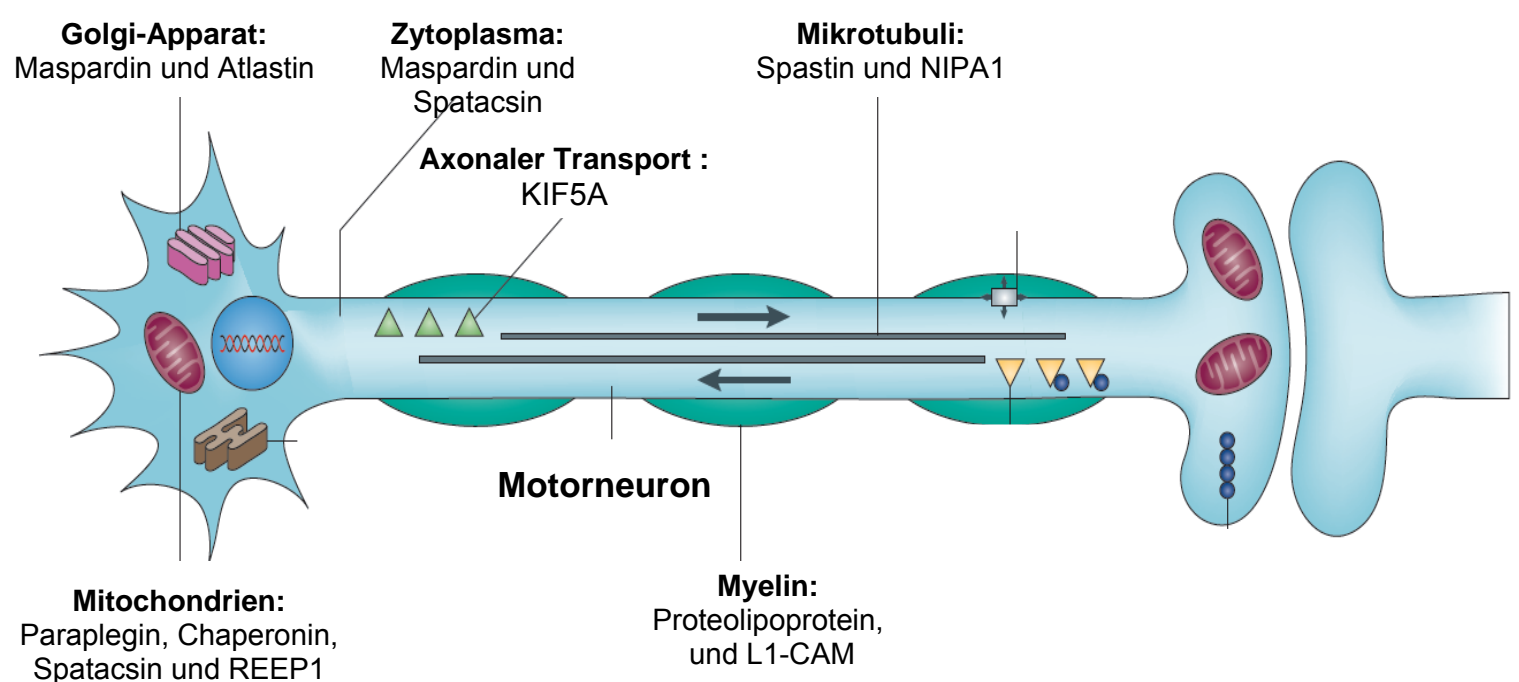

Abbildung 1: Ein Motorneuron mit der Darstellung der Lokalisation der HSP-Proteine und der durch deren Mutationen betroffenen Organellen. Paraplegin (SPG7), Chaperonin (SPG13), Spatacsin (SPG11) und REEP1 (SPG31) sind mitochondriale Proteine. Spastin (SPG4) und NIPA1 (SPG6) interagieren mit weiteren axonalen Transport-Proteinen. Maspardin (SPG21) und Atlastin (SPG3A) sind Proteine des Golgi-Apparates. Proteolipoprotein (SPG2) und L1-CAM (SPG1) sind Myelinproteine (Dion et al. 2009. Seite 777). 
Das weite Spektrum von funktionell unterschiedlichen Proteinen deutet auf einen gemeinsamen und bislang unbekannten biochemischen Mechanismus der axonalen Degeneration bei HSP hin (Fink 2006).

\subsection{Gegenstand der kumulativen Schrift}

Die Verdachtsdiagnose einer HSP wird aufgrund der progredienten spastischen Gangstörung und der eventuellen positiven Familienanamnese gestellt. Eine genetische Diagnose der HSP kann die klinische Diagnose sichern und kann vorteilhafte Auswirkungen auf die Behandlungsmaßnahmen der Symptome haben. Wird die verantwortliche Mutation bei dem Patienten identifiziert, kann nachfolgend eine Aussage über das Wiederholungsrisiko bei den Kindern getroffen werden. Ein entsprechender prädiktiver Gentest kann auch bei anderen Familienangehörigen angeboten werden.

Die genetische und klinische Variabilität stellt allerdings eine Herausforderung für die molekulargenetische Diagnostik dar. Trotz der in den letzten Jahren erzielten Fortschritte bei der Identifizierung der HSP-Gene kann die genetische Ursache der Erkrankung nur bei ca. 50\% der Familien aufgeklärt werden. Es besteht daher erheblicher Forschungsbedarf auf diesem Gebiet. Im Rahmen dieser kumulativen Doktorarbeit werden 3 Publikationen zum Thema HSP vorgestellt. In der ersten Publikation werden die Ergebnisse unserer molekulargenetischen Untersuchungen bei Patienten mit Mutationen im SPG4-Gen dargestellt (Shoukier et al. 2009). In der zweiten und dritten Arbeit werden die Ergebnisse einer funktionellen Evaluation ausgewählter Mutationen im SPG4-Gen (Klimpe et al. 2010) bzw. im SPG7-Gen (Bonn et al. 2010) beschrieben. 


\section{Material und Methoden}

Im Rahmen einer Stufendiagnostik erfolgt bei Verdacht auf eine ADHSP die Sequenzanalyse der SPG4-, SPG3A- und SPG31-Gene. Bei einem Erkrankungsalter von <10 Jahren wird zunächst eine Untersuchung auf Mutationen im SPG3A-Gen vorgenommen. Deutet der Stammbaum des Patienten auf eine ARHSP hin, wird zunächst eine Sequenzanalyse auf Mutationen im SPG7 und ggf. im SPG11-Gen durchgeführt. Die kodierenden exonischen Bereiche einschließlich flankierender intronischer Sequenzen der o.g. Gene werden mittels der PolymeraseKettenreaktion-Methode (PCR) amplifiziert, anschließend sequenziert und analysiert. Für die Detektion großer genomischer Rearrangements (Deletionen oder Duplikationen) wird nachfolgend die Multiplex-Ligation-dependent-ProbeAmplification-Methode (MLPA) eingesetzt, da große genomische Rearrangements mithilfe der Sequenzanalyse nicht erfasst werden können. Eine ausführliche Beschreibung der molekulargenetischen diagnostischen Methoden erfolgt im Methodenteil der jeweiligen Publikation. Die strukturellen und funktionellen Auswirkungen der bisher nicht beschriebenen Missense-Mutationen in der AAADomäne des Spastins wurden mithlife einer Computer-Modelling-Methode ermittelt. Unter Berücksichtigung der hexamerischen Struktur des Proteins wurden seine Tertiär- und Quartärstruktur in dem bisher bekannten Modell (Pantakani et al. 2008) modifiziert. Die in unserem Patientenkollektiv detektierten Missense-Mutationen wurden mithilfe des RasWin-Molecular-Graphics-Version 2.7.3 -Programms in dieses modifizierte Modell eingebaut und analysiert (Publikation I).

Splice-site-Mutationen machen etwa. 16.9\% der Mutationen im SPG4-Gen aus (HGMD Professional Mutation Database 2010.3). Mithilfe der ReverseTranskriptase-Polymerase-Kettenreaktion-Methode (RT-PCR) konnte gezeigt werden, dass die Mutation c.1414-1G>A in der splice acceptor site von Intron 11 sowie die Mutation c.1493+1G>A in der splice donor site in Intron 12 des SPG4Gens auf der cDNA-Ebene zum Wegfall von Exon 12 führen. Mithilfe eines quantitativen Allel-spezifischen Expressionsassays gelang der Nachweis eines threshold-effect-models für die HSP4 (Publikation II). 
Das SPG7-Gen kodiert für das Protein Paraplegin, welches als eine Untereinheit der hetero-oligomeric-mAAA-Protease in den Mitochondrien fungiert. In der Hefe besteht die mAAA-Protease aus den zwei Untereinheiten Yta10 und Yta12, und diese Protease ist essenziell für die Aufrechterhaltung der respiratorischen Aktivität (Arlt et al. 1998). Hefezellen mit fehlenden mAAA-Protease- Untereinheiten (Yta10 $\Delta$ Yta12 $\Delta$ ) weisen einen respiratorischen Mangel auf und können Glycerol sowie weitere nicht gärfähige Karbon-Ressourcen, welche für das Wachstum notwendig sind, nicht umsetzen. Allerdings kann die Expression der humanen $m A A A-P r o t e a s e$, bestehend aus Paraplegin und seinem Interaktionspartner AFG3L2, die Deletion von Yta10 und Yta12 funktionell komplementieren (Atorino et al. 2003). Bei einem Patienten aus unserem Kollektiv wurden unterschiedliche Mutationen im SPG7-Gen im heterozygoten Zustand detektiert. Diese Mutationen führen auf Proteinebene entweder zu einem Austausch von Aminosäuren oder zu einem vorzeitigen StoppKodon an verschiedenen Positionen des Paraplegins (p.G349S/p.W583C und p.A510V/p.N739KfsX741). In der dritten Publikation wird ein HefeKomplementations- Assay für den Nachweis der Pathogenität dieser Veränderungen verwendet. Eine ausführliche Beschreibung der verwendeten Methoden wird in der Publikation III gegeben. 


\section{Ergebnisse und Diskussion}

Mutationen im SPG4-Gen stellen die häufigste Ursache der HSP dar und wurden bei $15-40 \%$ der ADHSP-Patienten, abhängig von der ethnischen Herkunft der untersuchten Kohorte, gefunden (Sauter et al. 2002; McDermott et al. 2006). Darüber hinaus wurden bei ca. $12 \%$ der sporadischen HSP-Fälle Mutationen im SPG4-Gen detektiert (Depienne et al. 2006). Bislang sind 344 unterschiedliche Mutationen beschrieben worden (HGMD Professional Mutation Database 2010.3), die sich über das gesamte Gen verteilen. In der Publikation I werden die Ergebnisse der molekulargenetischen Untersuchungen auf Mutationen im SPG4-Gen in unserem Kollektiv von 200 HSP-Familien aufgeführt. Ziel der Studie war die Erweiterung des Mutationsspektrums und die Etablierung einer aussagekräftigen Genotyp-PhänotypKorrelation. Weitere Ziele der Studie waren, eine mögliche mutation-cluster-region im SPG4-Gen zu identifizieren und den strukturellen und funktionellen Effekt der Missense-Mutationen in der AAA-Domäne auf Proteinebene zu ermitteln.

In unserem Kollektiv konnten krankheitsverursachende Mutationen im SPG4-Gen (im heterozygoten Zustand) in 57 Familien detektiert werden. Damit konnten wir eine Mutationsdetektionsrate von 28,5\% verzeichnen, welche mit der Detektionsrate aus der Literatur (15-40\%) vergleichbar ist. Eine positive Familienanamnese, welche auf einen autosomal-dominanten Erbgang hindeutet, fand sich bei 99 Familien. Bei 55 Patienten handelte es sich offensichtlich um einen Einzelfall in der Familie (sog. sporadische Fälle), und bei den restlichen 55 Fällen konnte aufgrund der fehlenden klinischen Angaben der Vererbungsmodus nicht ermittelt werden. Betrachtet man lediglich die Gruppe der Familien mit einem autosomal dominanten Erbgang, so erhöht sich die Detektionsrate auf $36.4 \%$ (36/99). Bei den sporadischen Fällen beträgt diese lediglich 6,5\% (3/46; Tabelle 2 der Publikation I). Somit war die Detektionsrate bei Patienten mit sporadischer spastischer Paraplegie aus unserem Kollektiv geringer als die mit $12 \%$ in der Literatur angegebene Detektionsrate. Die Diskrepanz beruht wahrscheinlich auf genetisch bedingten Unterschieden zwischen den untersuchten Populationen. Eine 6.5\%ige Detektionsrate bei den sporadischen Fällen in unserem Kollektiv spiegelt nicht die Neumutationrate im SPG4-Gen wider. Bei den sporadischen Fällen wird häufig die Mutation nachträglich bei einem bislang klinisch unauffälligen Elternteil des Patienten ebenfalls nachgewiesen. Eine 
reduzierte Penetranz dürfte für diese große phänotypische Variabilität verantwortlich sein. Ein unauffälliger klinischer neurologischer Befund bei den Eltern und den Verwandten schließt daher die HSP keineswegs aus. Nur die molekulargenetische Diagnostik kann ggf. die Erkrankung ausschließen. Allerdings können im klinischen Alltag bei vielen Fällen die DNA-Proben der Verwandten nicht zur Verfügung gestellt werden, insbesondere wenn diese selbst keine Symptome der Erkrankung aufweisen.

Außerdem zeigte sich in unserer Studie kein signifikanter Unterschied zwischen der Gruppe der rHSP (Detektionsrate 29.4\% (32/109)) und der Gruppe der kHSP (Detektionsrate 21.7\% (5/23)). Hieraus lässt sich schließen, dass Mutationen im SPG4-Gen ebenfalls häufig für eine komplizierte Form der ADHSP ursächlich sein können. Laut Literaturangaben verursachen Mutationen im SPG4-Gen am ehesten eine reine Form der Erkrankung. Selten treten weitere Symptome wie z.B. eine mentale Retardierung, cerebrale Ataxien und Epilepsien auf (Santorelli et al. 2000). Allerdings lässt sich bei der HSP4 eine große Variabilität der Expression der klinischen Symptome selbst in einer Familie beobachten. Wir konnten in unserer Studie aufgrund der fehlenden klinischen Angaben der Familienangehörigen die Segregation der zusätzlichen Symptome bei kHSP mit der Mutation innerhalb der Familie nicht untersuchen. Daher ist die Dokumentation der klinischen Manifestationen bei den Betroffenen in der Familie von großer Bedeutung für die molekulargenetische Diagnostik und sollte in einem für die Erkrankung anerkannten Referenzzentrum erfolgen.

In unserem Kollektiv konnten alle Mutationstypen detektiert werden. Mit wenigen Ausnahmen (6 Mutationen) wurden nur familiäre Mutationen beobachtet. Von den 47 verschiedenen Mutationen waren 41 (87\%) Punktmutationen (18 MissenseMutationen, 8 Nonsense-Mutationen, 7 Deletionen, 3 Insertionen und 5 splice-siteMutationen) und 6 (13\%) waren große Deletionen auf genomischer Ebene. Ein Mutations-Clustering in der AAA-Domäne des Spastins wurde bereits in verschiedenen Patienten-Kohorten beobachtet (Fonknechten et al. 2000, Lindsey et al. 2000, Patrono et al. 2005). Dies konnte durch unsere Untersuchungen bestätigt werden. Wird allerdings die Lokalisation von allen bisher beschriebenenen Mutationen im SPG4-Gen zusammen ausgewertet, führt dies zur Identifizierung von 
insgesamt 4 mutation-cluster-Regionen: 1) der primary-cluster-Region in der AAADomäne, 2) der secondary-cluster-I-Region in der MIT-Domäne (microtubule interacting and trafficking), 3) der secondary-cluster-II-Region zwischen Aminosäuern 197 und 270, und 4) die secondary-cluster-III-Region in der MTBD-Domäne (microtubule-binding domain) von Spastin. Diese sind in Abbildung 1 der o.g. Publikation dargestellt. Eine so genannte hot-spot-mutation-Region ließ sich allerdings nicht definieren.

Etwa 95\% (17/18) der Missense-Mutationen liegen in der AAA-Domäne. Darüber hinaus wurden 85\% (22/26) der bisher nicht beschriebenen Mutationen (novel mutations) in dieser Domäne lokalisiert, darunter sind 10 Missense-Mutationen. Mithilfe einer Computer-gestützten modelling-Methode haben wir die möglichen strukturellen und funktionellen Auswirkungen dieser 10 Mutationen ermittelt. Dabei ließen sich diese Mutationen in 4 Untergruppen einteilen, nämlich die active-site motif-Mutationen, die pore-loop-residues-Mutationen, die key-protomer-interacting residues-Mutationen sowie eine Gruppe unklassifizierbarer Mutationen (Tabelle S3. und Abbildung S1 der Publikation I). Die Computer-basierte modelling-Methode ermöglicht die Beurteilung des funktionellen Effekts der Missense-Mutationen und kann somit die experimentellen Daten unterstützen.

Zur Beurteilung von Genotyp-Phänotyp-Korrelationen bei HSP4 wurde das Erkrankungsalter der Patienten als messbarer Parameter ausgewählt. In unserem Kollektiv gibt es Anhaltspunkte dafür, dass Missense-Mutationen mit einem früheren Beginn der Erkrankung korreliert sind. Allerdings sollte bedacht werden, dass aufgrund der kleinen Zahl der detektierten Mutationen diese Aussage nur unter Vorbehalt getätigt werden kann.

Es wurde vermutet, dass Mutationen im SPG4-Gen zum einen zu Haploinsuffizienz des Gens, zum anderen aber auch zu einem dominant-negativen Effekt führen. (Solowska et al. 2010). Des Weiteren wurde ein threshold effect model für Spastin diskutiert. Der threshold effect bedeutet, dass die Symptome der Erkrankung erst dann bei den Patienten auftreten, wenn der Prozentsatz des Wildtyp-Spastins (WtSpastin) unter einem Schwellenwert liegt. Ob der Schweregrad der Erkrankung sogar mit dem Spastin-Level korreliert, kann zur Zeit nicht beantwortet werden. Um dieses 
Modell zu überprüfen, haben wir eine Reverse-Transkriptase-PolymeraseKettenreaktion-Analyse (RT-PCR) in zwei HSP4-Familien mit zwei unterschiedlichen heterozygoten splice-site-Mutationen, nämlich die Mutation c.1414-1G>A in der splice acceptor site von Intron 11 bei der Familie 25913 und die Mutation c. 1493+1G>A in der splice donor site in Intron 12 bei der Familie 29804, vorgenommen. Auf cDNA-Ebene führen beide Mutationen zum Wegfall von Exon 12 des SPG4-Gens (Abbildung 2 der Publikation II). Allerdings war die Expression des mutierten Allels (Spastin__Exon12) weitaus schwächer als die vom Wt-Allel (Abbildung 1 der Publikation II). Ursächlich für die schwache Expression könnte entweder der nonsense-mediated-mRNA-decay (NMD)-Mechanismus oder das so genannte leaky splicing sein. Durch NMD werden normalerweise mRNAs mit einem frühzeitigen Stopp-Codon erkannt und mittels einer Endonuklease (Smg6) abgebaut. Die Bezeichnung leaky splicing bedeutet, dass die splice-site-Mutation möglicherweise keine vollständige Penetranz besitzt. Zur Quantifizierung der beiden Allele führten wir zunächst einen quantitativen Allel-spezifischen Expressionsassay (q-ASE) an mRNA isoliert aus Lymphozyten der Patienten durch. Um den NMDMechanismus zu blockieren, wurde die Blutprobe unmittelbar nach der Abnahme mit Puromycin behandelt. Anhand dieses Experiments konnte gezeigt werden, dass das Wt-Allel bei den Betroffenen unerwarteterweise einen Prozentsatz von $78.8 \pm 3.9 \%$

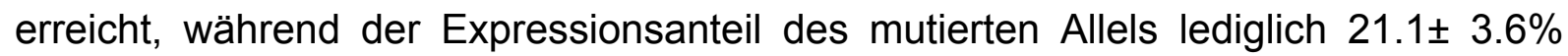
beträgt. Möglicherweise ist dies ein Hinweis darauf, dass beide Mutationen als leakysplicing-Mutationen wirken. Dadurch bleibt vom mutierten Allel jedoch eine gewisse Menge an residualem Wt-Spastin erhalten. Ohne eine Behandlung mit Puromycin wird der Anteil des mutierten Allels auf $8.3 \% \pm 1.3 \%$ gesenkt. Es kann davon ausgegangen werden, dass eine beachtliche Menge der mutierten mRNA durch den NMD-Mechanismus abgebaut wird.

Die Patienten in dieser Studie zeigen eine hohe phänotypische Variabilität auf, sogar innerhalb derselben Familie. Eine Korrelation zwischen dem Schweregrad des Phänotyps und dem Expressionslevel des Wt-Spastins konnte nicht festgestellt werden. Außerdem konnte das Vorliegen von 3 bekannten genetischen Modifiern (die Missense-Varianten p.S44L und p.P45Q im Exon 1 des SPG4-Gens bzw. p.G563A im Exon 12 des SPG13-Gens (SPG60) als mögliche Ursache dieser Variabilität ausgeschlossen werden. Zusammengefasst konnten also weder die 
intragenischen noch die intergenischen Faktoren, die diese klinische Variabilität begünstigen, identifiziert werden.

Im Institut für Humangenetik der Universitätsmedizin Göttingen werden auch molekulargenetische Untersuchungen bei Patienten zum Nachweis von Mutationen im SPG7-Gen durchgeführt. Mutationen in diesem Gen stellen die zweithäufigste Ursache (nach Mutationen im SPG11-Gen) einer ARHSP dar, und sie können sowohl eine unkomplizierte als auch eine komplizierte Form der Erkrankung verursachen. Oft werden nach den molekulargenetischen Untersuchungen bei den Patienten unklassifizierbare Varianten (UVs) im SPG7-Gen im compound-heterozyoten- oder homozygoten Zustand detektiert, die aber ebenfalls in der Kontrollgruppe beobachtet werden können (Brugman et al. 2008). Dies erschwert die Beurteilung der klinischen Relevanz solcher Veränderungen. Ein Beispiel dafür ist der Basenaustausch (c.1529C>T) im Exon 11 des SPG7-Gens. Dieser Basenaustausch führt auf Proteinebene zu einem Aminosäureaustausch von Alanin zu Valin an Position 510 des Paraplegins (p.A510V). Diese Veränderung wurde sowohl bei $1 \%$ der HSPPatienten als auch bei $4 \%$ der Probanden in einer Kontrollgruppe (heterozygot) gefunden. Es handelt sich hier wahrscheinlich um einen Polymorphismus, dessen Rolle als krankheitsverursachende Mutation jedoch nicht ausgeschlossen werden kann (Elleuch et al. 2006). Wir haben in zwei Familien aus unserem ARHSP-Kollektiv vier solcher UVs identifiziert, nämlich die heterozygoten Basenaustausche c.1045G>A (p.G349S) und c.1749G>C (p.W583C) beim Patienten 28142 sowie den heterozygoten Basenaustausch c.1529C>T (p.A510V) und die heterozygote Insertion c.2215_2216insA (p.N739KfsX741) beim Patienten 28135. Ein Verfahren für die funktionelle Evaluation der UVs, beispielsweise mittels Zellmodellen oder Tiermodellen, war bislang nicht etabliert. Dies war das Ziel unserer experimentellen Arbeit, deren Ergebnisse in der Publikation III dargestellt sind und im Folgenden weiter erläutert werden.

Das vom SPG7 kodierte Protein Paraplegin fungiert in den Mitochondrien als eine Untereinheit der hetero-oligomeric-mAAA-Protease. Die zweite Untereinheit der mAAA-Protease in menschlichen Zellen besteht aus dem Protein AFG3L2. Die $m A A A-P r o t e a s e$ bildet sowohl in menschlichen Zellen als auch in der Hefe den Hauptbestandteil des mitochondrialen Qualitätskontrollsystems aus (Nolden et al. 
2005). Die Hefeproteine Yta10 und Yta12 sind die Homologen zu den menschlichen Paraplegin- und AFG3L2-Proteinen (Atorino et al. 2003). Eine wichtige Funktion der mAAA-Protease ist der Abbau falsch gefalteter Proteine (Arlt et al. 1998). Darüber hinaus weisen Hefezellen mit fehlenden mAAA-Protease-Untereinheiten (Yta10 $\Delta$ Yta12 $\Delta$ ) einen respiratorischen Mangel auf und sie können Glycerol sowie weitere nicht-fermentierbare Kohlenstoffe nicht verstoffwechseln. Dies führt zu einer starken Reduktion des Wachstums der Hefezellen bei $30^{\circ} \mathrm{C}$ in dem Glycerolenthaltenden YPG-Medium . Der Verlust der respiratorischen Kompetenz ist dadurch bedingt, dass die Reifung und die Prozessierung von zwei weiteren Proteinen, nämlich der Cytochrom c-Peroxidase (Ccp1) und dem MrpL32, ebenfalls von der $m A A A$-Protease-Aktivität abhängig sind. Beide Proteine sind Untereinheiten des mitochondrialen Ribosoms (Rugarli und Langer, 2006). Allerdings kann die Expression der humanen mAAA-Protease bzw. die Expression des Paraplegins alleine in den Hefezellen, trotz eines inaktivierten und mitexprimierten AFG3L2Proteins, die Deletion von Yta10 und Yta12 funktionell komplementieren (Atorino et al. 2003). Wir haben daher den Hefe-Komplementations-Assay für den Nachweis der Pathogenität der bei unseren Patienten gefundenen Veränderungen (p.G349S, p.W583C, p.A510V und p.N739KfsX741) verwendet (Abbildung 1 der Publikation III). Das Prinzip dieses Assays ist die Co-Expression des "mutierten“ Paraplegins und eines entweder durch die Mutation E575Q in der proteolytischen site oder durch die Mutation K354A im Walker-A-Motiv inaktivierten AFG3L2-Proteins in den Yta10 $\Delta$ Yta12 $\Delta$-Hefezellen. Die respiratorische Kompetenz der Hefezellen sowie die proteolytische Funktion der mAAA-Protease, bemessen durch die erhaltene Fähigkeit, das MrpL32-Protein zu spalten und somit aktivieren zu können, wurden ausgewertet. Mithilfe dieser Methode gelang uns der Nachweis und die Erklärung der Pathogenität der vier Mutationen (p.G349S, p.W583C, p.A510V und p.N739KfsX741) im SPG7-Gen (Abbildung 3 und 4 der Publikation III). Diese Methode kann weiterhin für die Beurteilung der klinischen Relevanz weiterer Mutationen im SPG7-Gen verwendet werden. Die damit erhaltenen Informationen können so zur Verbesserung unserer Kenntnisse über die Funktion(en) des Paraplegins beitragen. 


\section{Literaturverzeichnis}

Abel A, Fonknechten N, Hofer A, Durr A, Cruaud C, Voit T, Weissenbach J, Brice A, Klimpe S, Auburger $G$ et al. (2004): Early onset autosomal dominant spastic paraplegia caused by novel mutations in SPG3A.Neurogenetics $\underline{5}, 239-243$

Arlt H, Steglich G, Perryman R, Guiard B, Neupert W, Langer T (1998): The formation of respiratory chain complexes in mitochondria is under the proteolytic control of the m-AAA protease. EMBO J $\underline{17}, 4837-4847$

Atorino L, Silvestri L, Koppen M, Cassina L, Ballabio A, Marconi R, Langer T, Casari G (2003): Loss of m-AAA protease in mitochondria causes complex I deficiency and increased sensitivity to oxidative stress in hereditary spastic paraplegia. J Cell Biol $\underline{163}, 777-787$

Blumen SC, Bevan S, Abu-Mouch S, Negus D, Kahana M, Inzelberg R, Mazarib A, Mahamid A, Carasso RL, Slor $\mathrm{H}$ et al. (2003): A locus for complicated hereditary spastic paraplegia maps to chromosome 1q24-q32. Ann Neurol 54, 796-803

Botzolakis EJ, Zhao J, Gurba KN, Macdonald RL, Hedera P (2010): The effect of HSP-causing mutations in SPG3A and NIPA1 on the assembly, trafficking, and interaction between atlastin-1 and NIPA1. (Mol Cell Neurosci , im Druck)

Boukhris A, Feki I, Elleuch N, Miladi MI, Boland-Auge A, Truchetto J, Mundwiller E, Jezequel N, Zelenika D, Mhiri C et al. (2010): A new locus (SPG46) maps to 9p21.2q21.12 in a Tunisian family with a complicated autosomal recessive hereditary spastic paraplegia with mental impairment and thin corpus callosum. Neurogenetics $\underline{11}, 441-448$

Bouslam N, Benomar A, Azzedine H, Bouhouche A, Namekawa M, Klebe S, Charon C, Durr A, Ruberg M, Brice A et al. (2005): Mapping of a new form of pure autosomal recessive spastic paraplegia (SPG28). Ann Neurol $\underline{57}$, 567-571

Brugman F, Scheffer H, Wokke JH, Nillesen WM, de Visser M, Aronica E, Veldink $\mathrm{JH}$, van den Berg LH (2008): Paraplegin mutations in sporadic adult-onset upper motor neuron syndromes. Neurology $\underline{71}, 1500-1505$

Depienne C, Tallaksen C, Lephay JY, Bricka B, Poea-Guyon S, Fontaine B, Labauge P, Brice A, Durr A (2006): Spastin mutations are frequent in sporadic spastic paraparesis and their spectrum is different from that observed in familial cases. $J$ Med Genet $\underline{43}$, 259-265

Depienne C, Fedirko E, Faucheux JM, Forlani S, Bricka B, Goizet C, Lesourd S, Stevanin G, Ruberg M, Durr A et al. (2007): A de novo SPAST mutation leading to somatic mosaicism is associated with a later age at onset in HSP. Neurogenetics $\underline{8}$, 231-233

Dick KJ, Eckhardt M, Paisan-Ruiz C, Alshehhi AA, Proukakis C, Sibtain NA, Maier H, Sharifi R, Patton MA, Bashir $W$ et al. (2010): Mutation of FA2H underlies a 
complicated form of hereditary spastic paraplegia (SPG35). Hum Mutat. 31, 12511260

Dion PA, Daoud H, Rouleau GA (2009): Genetics of motor neuron disorders: new insights into pathogenic mechanisms. Nat Rev Genet 10, 769-782

Dursun U, Koroglu C, Kocasoy Orhan E, Ugur SA, Tolun A (2009): Autosomal recessive spastic paraplegia (SPG45) with mental retardation maps to 10q24.3q25.1. Neurogenetics $\underline{10}, 325-331$

Edgar JM, McLaughlin M, Yool D, Zhang SC, Fowler JH, Montague P, Barrie JA, McCulloch MC, Duncan ID, Garbern J et al. (2004): Oligodendroglial modulation of fast axonal transport in a mouse model of hereditary spastic paraplegia. J Cell Biol $\underline{166}, 121-131$

Elleuch N, Depienne C, Benomar A, Hernandez AM, Ferrer X, Fontaine B, Grid D, Tallaksen CM, Zemmouri R, Stevanin G et al. (2006): Mutation analysis of the paraplegin gene (SPG7) in patients with hereditary spastic paraplegia. Neurology $\underline{66}$, 654-659

Erichsen AK, Koht J, Stray-Pedersen A, Abdelnoor M, Tallaksen CM (2009): Prevalence of hereditary ataxia and spastic paraplegia in southeast Norway: a population-based study. Brain 132, 1577-1588

Filla A, De Michele G, Barbieri F, Campanella G (1992): Early onset hereditary ataxias of unknown etiology. Review of a personal series. Acta Neurol (Napoli) 14 , $420-430$

Fink JK (2006): Hereditary spastic paraplegia. Curr Neurol Neurosci Rep $\underline{6}$, 65-76

Fink JK, Wu CT, Jones SM, Sharp GB, Lange BM, Lesicki A, Reinglass T, Varvil T, Otterud B, Leppert M (1995): Autosomal dominant familial spastic paraplegia: tight linkage to chromosome 15q.Am J Hum Genet $\underline{56}$, 188-192

Finsterer J (2003): Hereditäre spastische Paraplegien. Nervenarzt $\underline{74}$, 497-504

Fonknechten N, Mavel D, Byrne P, Davoine CS, Cruaud C, Bonsch D, Samson D, Coutinho P, Hutchinson M, McMonagle P et al. (2000): Spectrum of SPG4 mutations in autosomal dominant spastic paraplegia. Hum Mol Genet $\underline{9}$, 637-644

Hanein S, Durr A, Ribai P, Forlani S, Leutenegger AL, Nelson I, Babron MC, Elleuch N, Depienne C, Charon C et al. (2007): A novel locus for autosomal dominant "uncomplicated" hereditary spastic paraplegia maps to chromosome 8p21.1-q13.3. Hum Genet 122, 261-273

Hansen JJ, Durr A, Cournu-Rebeix I, Georgopoulos C, Ang D, Nielsen MN, Davoine CS, Brice A, Fontaine B, Gregersen N et al. (2002): Hereditary spastic paraplegia SPG13 is associated with a mutation in the gene encoding the mitochondrial chaperonin Hsp60. Am J Hum Genet 므, 1328-1332 
Hazan J, Lamy C, Melki J, Munnich A, de Recondo J, Weissenbach J (1993): Autosomal dominant familial spastic paraplegia is genetically heterogeneous and one locus maps to chromosome 14q. Nat Genet $\underline{5}, 163-167$

Hazan J, Fontaine B, Bruyn RP, Lamy C, van Deutekom JC, Rime CS, Durr A, Melki J, Lyon-Caen O, Agid Y et al. (1994): Linkage of a new locus for autosomal dominant familial spastic paraplegia to chromosome 2p. Hum Mol Genet $\underline{3}$, 1569-1573

Hentati A, Pericak-Vance MA, Hung WY, Belal S, Laing N, Boustany RM, Hentati F, Ben Hamida M, Siddique T (1994): Linkage of 'pure' autosomal recessive familial spastic paraplegia to chromosome 8 markers and evidence of genetic locus heterogeneity. Hum Mol Genet $\underline{3}, 1263-1267$

Hodgkinson CA, Bohlega S, Abu-Amero SN, Cupler E, Kambouris M, Meyer BF, Bharucha VA (2002): A novel form of autosomal recessive pure hereditary spastic paraplegia maps to chromosome 13q14. Neurology $\underline{59}$, 1905-1909

Hughes CA, Byrne PC, Webb S, McMonagle P, Patterson V, Hutchinson M, Parfrey NA (2001): SPG15, a new locus for autosomal recessive complicated HSP on chromosome 14q.Neurology $\underline{56}, 1230-1233$

Jouet M, Rosenthal A, Armstrong G, MacFarlane J, Stevenson R, Paterson J, Metzenberg A, lonasescu V, Temple K, Kenwrick S (1994): X-linked spastic paraplegia (SPG1), MASA syndrome and X-linked hydrocephalus result from mutations in the L1 gene. Nat Genet $\underline{7}, 402-407$

Klebe S, Azzedine H, Durr A, Bastien P, Bouslam N, Elleuch N, Forlani S, Charon C, Koenig M, Melki J et al. (2006): Autosomal recessive spastic paraplegia (SPG30) with mild ataxia and sensory neuropathy maps to chromosome 2 q37.3. Brain $\underline{129}$, 1456-1462

Kobayashi H, Hoffman EP, Marks HG (1994): The rumpshaker mutation in spastic paraplegia. Nat Genet $\underline{7}, 351-352$

Lin P, Li J, Liu Q, Mao F, Qiu R, Hu H, Song Y, Yang Y, Gao G, Yan C et al. (2008): A missense mutation in SLC33A1, which encodes the acetyl-CoA transporter, causes autosomal-dominant spastic paraplegia (SPG42).Am J Hum Genet $\underline{\text { 83, }}$, 752-759

Lindsey JC, Lusher ME, McDermott CJ, White KD, Reid E, Rubinsztein DC, Bashir R, Hazan J, Shaw PJ, Bushby KM (2000): Mutation analysis of the spastin gene (SPG4) in patients with hereditary spastic paraparesis.J Med Genet $\underline{37}, 759-765$

Lo Nigro C, Cusano R, Scaranari M, Cinti R, Forabosco P, Morra VB, De Michele G, Santoro L, Davies S, Hurst J et al. (2000): A refined physical and transcriptional map of the SPG9 locus on 10q23.3-q24.2. Eur J Hum Genet $\underline{8}, 777-782$

Ludolph A.C.: Toxische Myelopathien; in: Klinische Neurologie; Band IV; hrsg. Berlit P.; Springer- Verlag Heidelberg 2006, 561-563

Macedo-Souza LI, Kok F, Santos S, Licinio L, Lezirovitz K, Nascimento RM, Bueno C, Martyn M, Leao EK, Zatz M (2008): Reevaluation of a large family defines a new 
locus for X-linked recessive pure spastic paraplegia (SPG34) on chromosome Xq25. Neurogenetics $\underline{9}, 225-226$

Mannan AU, Krawen P, Sauter SM, Boehm J, Chronowska A, Paulus W, Neesen J, Engel W (2006): ZFYVE27 (SPG33), a novel spastin-binding protein, is mutated in hereditary spastic paraplegia. Am J Hum Genet $\underline{79}$, 351-357

McDermott CJ, Burness CE, Kirby J, Cox LE, Rao DG, Hewamadduma C, Sharrack B, Hadjivassiliou M, Chinnery PF, Dalton A et al. (2006): Clinical features of hereditary spastic paraplegia due to spastin mutation. Neurology $\underline{67}, 45-51$

Meijer IA, Cossette P, Roussel J, Benard M, Toupin S, Rouleau GA (2004): A novel locus for pure recessive hereditary spastic paraplegia maps to 10q22.1-10q24.1.Ann Neurol $\underline{56}, 579-582$

Nagaraj K, Kristiansen LV, Skrzynski A, Castiella C, Garcia-Alonso L, Hortsch M (2009): Pathogenic human L1-CAM mutations reduce the adhesion-dependent activation of EGFR. Hum Mol Genet 18, 3822-3831

Nolden M, Ehses S, Koppen M, Bernacchia A, Rugarli El, Langer T (2005): The mAAA protease defective in hereditary spastic paraplegia controls ribosome assembly in mitochondria. Cell $\underline{123}, 277-289$

Orlacchio A, Kawarai T, Gaudiello F, St George-Hyslop PH, Floris R, Bernardi G (2005): New locus for hereditary spastic paraplegia maps to chromosome 1p31.11p21.1. Ann Neurol $\underline{58}, 423-429$

Orlacchio A, Patrono C, Gaudiello F, Rocchi C, Moschella V, Floris R, Bernardi G, Kawarai T (2008): Silver syndrome variant of hereditary spastic paraplegia: A locus to $4 p$ and allelism with SPG4. Neurology $\underline{70}, 1959-1966$

Pantakani DV, Swapna LS, Srinivasan N, Mannan AU (2008): Spastin oligomerizes into a hexamer and the mutant spastin (E442Q) redistribute the wild-type spastin into filamentous microtubule. J Neurochem $\underline{106}, 613-624$

Patrono C, Scarano V, Cricchi F, Melone MA, Chiriaco M, Napolitano A, Malandrini A, De Michele G, Petrozzi L, Giraldi C et al. (2005): Autosomal dominant hereditary spastic paraplegia: DHPLC-based mutation analysis of SPG4 reveals eleven novel mutations. Hum Mutat $\underline{25}, 506$

Proukakis C, Cross H, Patel H, Patton MA, Valentine A, Crosby AH (2004): Troyer syndrome revisited. A clinical and radiological study of a complicated hereditary spastic paraplegia. J Neurol 251, 1105-1110

Rainier S, Sher C, Reish O, Thomas D, Fink JK (2006): De novo occurrence of novel SPG3A/atlastin mutation presenting as cerebral palsy. Arch Neurol $\underline{63}, 445-447$

Rainier S, Bui M, Mark E, Thomas D, Tokarz D, Ming L, Delaney C, Richardson RJ, Albers JW, Matsunami $\mathrm{N}$ et al. (2008): Neuropathy target esterase gene mutations cause motor neuron disease. Am J Hum Genet 82, 780-785 
Reid E, Dearlove AM, Osborn O, Rogers MT, Rubinsztein DC (2000): A locus for autosomal dominant "pure" hereditary spastic paraplegia maps to chromosome 19q13. Am J Hum Genet $\underline{66}$, 728-732

Reid E, Kloos M, Ashley-Koch A, Hughes L, Bevan S, Svenson IK, Graham FL, Gaskell PC, Dearlove A, Pericak-Vance MA et al. (2002): A kinesin heavy chain (KIF5A) mutation in hereditary spastic paraplegia (SPG10). Am J Hum Genet $\underline{71}$, 1189-1194

Rugarli El, Langer T (2006): Translating m-AAA protease function in mitochondria to hereditary spastic paraplegia. Trends Mol Med 12, 262-269

Santorelli FM, Patrono C, Fortini D, Tessa A, Comanducci G, Bertini E, Pierallini A, Amabile GA, Casali C (2000): Intrafamilial variability in hereditary spastic paraplegia associated with an SPG4 gene mutation. Neurology $\underline{55}, 702-705$

Sauter S, Jürgen N, Paulus W, Engel W (2002): Hereditäre spastische Paraplegie Dtsch Ärztebl 99 Heft 7: A 434-440

Simpson MA, Cross H, Proukakis C, Pryde A, Hershberger R, Chatonnet A, Patton MA, Crosby AH (2003): Maspardin is mutated in mast syndrome, a complicated form of hereditary spastic paraplegia associated with dementia. Am J Hum Genet $\underline{73}$, $1147-1156$

Solowska JM, Garbern JY, Baas PW (2010): Evaluation of loss of function as an explanation for SPG4-based hereditary spastic paraplegia. Hum Mol Genet $\underline{19}$, 27672779

Somasundaram S, Raghavendra S, Singh A, Kesavadas C, Nair M (2007): Hereditary spastic paraplegia with a thin corpus callosum. Pediatr Radiol $\underline{37}, 503-505$

Stevanin G, Paternotte C, Coutinho P, Klebe S, Elleuch N, Loureiro JL, Denis E, Cruz VT, Durr A, Prud'homme JF et al. (2007): A new locus for autosomal recessive spastic paraplegia (SPG32) on chromosome 14q12-q21. Neurology $\underline{68}, 1837-1840$

Tamagaki A, Shima M, Tomita R, Okumura M, Shibata M, Morichika S, Kurahashi H, Giddings JC, Yoshioka A, Yokobayashi Y (2000): Segregation of a pure form of spastic paraplegia and NOR insertion into Xq11.2. Am J Med Genet $\underline{94}, 5-8$

Valdmanis PN, Meijer IA, Reynolds A, Lei A, MacLeod P, Schlesinger D, Zatz M, Reid E, Dion PA, Drapeau P et al. (2007): Mutations in the KIAA0196 gene at the SPG8 locus cause hereditary spastic paraplegia. Am J Hum Genet 으, 152-161

Valente EM, Brancati F, Caputo V, Bertini E, Patrono C, Costanti D, Dallapiccola B (2002): Novel locus for autosomal dominant pure hereditary spastic paraplegia (SPG19) maps to chromosome 9q33-q34. Ann Neurol 51, 681-685

Vazza G, Zortea M, Boaretto F, Micaglio GF, Sartori V, Mostacciuolo ML (2000): A new locus for autosomal recessive spastic paraplegia associated with mental retardation and distal motor neuropathy, SPG14, maps to chromosome 3q27-q28. Am J Hum Genet $\underline{67}$, 504-509 
Warner TT, Patel H, Proukakis C, Reed JA, McKie L, Wills A, Patton MA, Crosby AH (2004): A clinical, genetic and candidate gene study of Silver syndrome, a complicated form of hereditary spastic paraplegia. J Neurol 251, 1068-1074

Wilkinson PA, Simpson MA, Bastaki L, Patel H, Reed JA, Kalidas K, Samilchuk E, Khan R, Warner TT, Crosby AH (2005): A new locus for autosomal recessive complicated hereditary spastic paraplegia (SPG26) maps to chromosome 12p11.112q14. J Med Genet $\underline{42}, 80-82$

Winner B, Schulte-Mattler W, Uyanik G, Hehr U, Winkler J (2004) Diagnose und Therapie der hereditären spastischen Paraplegie (HSP): Kausale Behandlung bleibt Zukunftsmusik. Neurotransmitter $\underline{10}$, 55-59.

Zortea M, Vettori A, Trevisan CP, Bellini S, Vazza G, Armani M, Simonati A, Mostacciuolo ML (2002): Genetic mapping of a susceptibility locus for disc herniation and spastic paraplegia on 6q23.3-q24.1.J Med Genet 39, 387-390

Zuchner S, Wang G, Tran-Viet KN, Nance MA, Gaskell PC, Vance JM, Ashley-Koch $A E$, Pericak-Vance MA (2006): Mutations in the novel mitochondrial protein REEP1 cause hereditary spastic paraplegia type 31. Am J Hum Genet $\underline{79}$, 365-369 


\section{Publikationen}

\section{Publikation I:}

Shoukier M, Neesen J, Sauter SM, Argyriou L, Doerwald N, Pantakani DV, Mannan AU (2009): Expansion of mutation spectrum, determination of mutation cluster regions and predictive structural classification of SPAST mutations in hereditary spastic paraplegia. Eur J Hum Genet 17,187-194

\section{Publikation II:}

Klimpe S, Zibat A, Zechner U, Wellek B, Shoukier M, Sauter SM, Pantakani DV, Mannan AU. (2010): Evaluating the effect of spastin splice mutations by quantitative allele-specific expression assay. (Eur J Neurol, im Druck)

\section{Publikation III:}

Bonn F, Pantakani K, Shoukier M, Langer T, Mannan AU (2010) Functional evaluation of paraplegin mutations by a yeast complementation assay. Hum Mutat $\underline{31}, 617-21$ 


\subsection{Publikation I}

Expansion of mutation spectrum, determination of mutation cluster regions and predictive structural classification of SPAST mutations in hereditary spastic paraplegia

DOI: 10.1038/ejhg.2008.147

\section{Der Status der Publikation:}

Die Arbeit ist in der Zeitschrift European Journal of Human Genetics, Band 17(2009), Seiten 187-194, erschienen. Der 5-Year Journal Impact Factor (2009) ist 3.845 .

\section{Die Namen der Koautoren:}

Moneef Shoukier*, Juergen Neesen*, Simone M Sauter, Loukas Argyriou, Nadine Doerwald, Krishna D.V. Pantakani und Ashraf U. Mannan

* Die Autoren trugen zu gleichen Anteilen zu der Arbeit bei

\section{Der Anteil der Koautoren an dem Gesamtprojekt:}

Moneef Shoukier: Die Durchführung der molekulargenetischen Untersuchungen (inklusive der MLPA-Analyse) bei einem Teil des Patientenkollektives sowie die Auswertung der Daten aus dem gesamten Kollektiv hinsichtlich der GenotypPhänotyp-Korrelation und die Beteiligung an der Abfassung des Manuskripts

Juergen Neesen, Simone M Sauter, Loukas Argyriou und Nadine Doerwald: Die Durchführung der Sequenzierungsanalyse des SPG4-Gens bei den restlichen Patienten

Krishna D.V. Pantakani: das Computer-Modelling und Mutation-clustering im SPG4Gen

Ashraf U. Mannan : Studiendesign und Korrektor des Manuskripts 


\title{
Expansion of mutation spectrum, determination of mutation cluster regions and predictive structural classification of SPAST mutations in hereditary spastic paraplegia
}

\author{
Moneef Shoukier ${ }^{1,2}$, Juergen Neesen ${ }^{1,2,3}$, Simone M Sauter ${ }^{1}$, Loukas Argyriou ${ }^{1}$, \\ Nadine Doerwald ${ }^{1}$, DV Krishna Pantakani ${ }^{1}$ and Ashraf U Mannan ${ }^{*, 1}$ \\ ${ }^{1}$ Institute of Human Genetics, University of Goettingen, Goettingen, Germany
}

The SPAST gene encoding for spastin plays a central role in the genetically heterogeneous group of diseases termed hereditary spastic paraplegia (HSP). In this study, we attempted to expand and refine the genetic and phenotypic characteristics of SPAST associated HSP by examining a large cohort of HSP patients/families. Screening of 200 unrelated HSP cases for mutations in the SPAST gene led to detection of 57 mutations $(28.5 \%)$, of which 47 were distinct and 29 were novel mutations. The distribution analysis of known SPAST mutations over the structural domains of spastin led to the identification of several regions where the mutations were clustered. Mainly, the clustering was observed in the AAA (ATPases associated with diverse cellular activities) domain; however, significant clustering was also observed in the MIT (microtubule interacting and trafficking), MTBD (microtubule-binding domain) and an $\mathrm{N}$-terminal region (228-269 residues). Furthermore, we used a previously generated structural model of spastin as a framework to classify the missense mutations in the AAA domain from the HSP patients into different structural/functional groups. Our data also suggest a tentative genotype-phenotype correlation and indicate that the missense mutations could cause an earlier onset of the disease.

European Journal of Human Genetics (2009) 17, 187-194; doi:10.1038/ejhg.2008.147; published online 13 August 2008

Keywords: SPAST; spastin; HSP; mutation

Introduction

Hereditary spastic paraplegias (HSPs), also known as the Strümpell-Lorrain syndrome, are a group of neurodegenerative disorders caused by monogenic mutations. The universal clinical feature of the disease is progressive bilateral weakness and spasticity of the lower limbs. ${ }^{1}$

*Correspondence: Dr AU Mannan, Institute of Human Genetics, University of Goettingen, Heinrich-Dueker-Weg 12, D-37073, Goettingen, Germany. Tel: + 49551 397522; Fax + 49551399303 ; E-mail: amannan@gwdg.de

${ }^{2}$ These authors contributed equally to this work

${ }^{3}$ Current address: Department of Medical Genetics, Medical University of Vienna, Vienna, Austria

Received 15 January 2008; revised 9 July 2008; accepted 11 July 2008; published online 13 August 2008
Histopathological studies of HSP patients revealed selective degeneration of some of the longest axons. The degenerative process initially affects the distal ends of these axons and then proceeds proximally toward the cell body. ${ }^{2,3}$ On the basis of clinical features, HSP can be classified into two forms: the pure and the complex HSP. In pure HSP, spasticity occurs in relative isolation; however, when additional neurological or non-neurological symptoms are associated with spasticity then it is termed as complex HSP. ${ }^{4,5}$

HSPs are genetically heterogeneous and different modes of inheritance are reported, including autosomal dominant, recessive and X-linked HSP; within each inheritance group, there is further locus heterogeneity. Fifteen of the 


$\frac{17 p 9}{188} \quad \begin{array}{r}\text { Mutational spectrum in SPAST gene } \\ \text { M Shoukier et ai }\end{array}$

HSP genes have been identified. However, mutations in the SPAST gene (MIM 604277) encoding for spastin protein is the most common cause of $\mathrm{HSP}^{6}$ and accounts for $15-40 \%$ of all AD-HSP cases, depending upon the ethnic origin of the selected cohort of patients. ${ }^{6-12}$ The prevalence of SPAST mutations in sporadic cases and with uncertain family history is much lower $(12-18 \%) .^{13,14}$

Spastin belongs to the AAA (ATPases associated with diverse cellular activities) family of proteins. ${ }^{15-17}$ The AAA proteins are proven or putative ATPases and they are characterized by a conserved C-terminal domain containing one or two AAA cassettes. ${ }^{15}$ Apart from the AAA domain, these proteins consist of various other domains, which interact with adapter proteins to generate the structural and functional diversity of the family. ${ }^{16,18}$

Screening for mutations in the SPAST gene by various groups has identified over 224 different mutations in most exons except for exon 4 , which is alternatively spliced. The SPAST mutations are summarized in the Human Gene Mutation Database Professional release 7.1 (http:// www.biobase.de/hgmd/pro/start.php). Different types of DNA alterations are detected in the SPAST gene, including missense, nonsense, splice site mutations and insertions/ deletions. Recent studies used a SPAST-specific multiplex ligation-dependent probe amplification (MLPA) assay to demonstrate that a large proportion (18-20\%) of patients with unlinked HSP, in fact, carry large deletions in the SPAST gene. ${ }^{19,20}$ These findings further broaden the spectrum of the SPAST mutations.

From a diagnostic point of view, unfortunately, there are no common mutations in SPAST, with most families having private mutations. Moreover, there are neither obvious genotype-phenotype correlations between different types of spastin mutations, nor any hot spot regions for SPAST mutations have been identified. Therefore, screening of the complete coding sequence of SPAST is necessary for the detection of mutations.

\section{Materials and methods}

HSP cases/families

Blood samples from 200 unrelated HSP individuals/ families, primarily from Germany were referred to Goettingen Molecular Genetics Service for diagnostic testing of the SPAST gene. Clinical data of these patients were obtained by clinical evaluations from the referring neurologist. All probands were selected on the basis of Harding's accepted criteria for the definition of the clinical status of HSP. ${ }^{21}$ For ascertaining, a patient as HSP case following clinical features were assessed/observed in the lower limbs (lower extremities) of the patient; gait disorder owing to spastic paraparesis, spastic hypertonia, positive Babinski sign, ankle clonus, hyperreflexia, reduced pallesthesia and paresis. In addition, for complex HSP, cognitive deficits and other neurological/non-neurological symptoms were also considered. The age at onset (AAO) was determined by the referring neurologist after clinical evaluation and consulting with the patient. If required, additional family members were also consulted to corroborate the AAO. In our HSP cohort, 99 cases showed familial inheritance, 46 sporadic cases and in 55 cases, we could not ascertain the mode of inheritance. In this cohort, there were 109 pure HSP, 23 complex HSP and 68 unknown cases. Informed consent was obtained from all probands.

\section{Mutation screening and detection}

Genomic DNA from peripheral blood leukocytes of patients was isolated using standard procedures. The 17 exons of the SPAST gene (accession no. NM_014946.3) and flanking intronic sequences were amplified by PCR. Primer sequences and PCR conditions are available on request. Purification of PCR products was performed using a PCR purification kit (Millipore). The purified PCR products were sequenced using both forward and reverse primers (which were used for the PCR amplification) using ET reaction kit (Amersham Biosciences) on a MegaBACE 500 sequencer (Amersham Biosciences). Nucleotide variations revealed by first sequencing reaction were verified by second independent PCR and sequencing reaction. All sequence variants reported here were checked in a panel of 50 healthy unrelated subjects recruited randomly from the German population.

\section{MLPA analysis}

MLPA was performed with $200 \mathrm{ng}$ of genomic DNA according to manufacturer's instructions using the P165 Salsa MLPA HSP probe set (MRC-Holland). Probe amplification products were run on an ABI 3130 DNA Analyzer using Liz600 size standard (Applied Biosystems). MLPA peak plots were visualized, normalized and the dosage ratios were calculated by using GeneMarker Software v1.51 (Soft Genetics LLC). Owing to variation in each assay performance, we used dosage ratio values of $\leq 0.7$ and $\geq 1.35$ as our boundaries for deletions and duplications, respectively.

\section{Detection of break points for small insertions and} deletions

To determine the precise breakpoints of small insertions and deletions in the SPAST gene, the PCR amplicons were cloned into pGEMT Easy vector (Promega) according to the manufacturer's instructions. Plasmid DNA from at least 10 independent bacterial colonies were sequenced in both directions using vector-specific primers (T7 and SP6) using standard protocol.

\section{Modeling of the AAA domain of spastin}

The AAA ATPase domain of spastin was modeled on the basis of the tertiary structures of two templates (PDB codes: $1 \mathrm{xwi}$ and $1 \mathrm{~s} 3 \mathrm{~s}$ ) using MODELLER Version 8.0 program. $^{22}$ 
The generated models were energy-minimized using the Kollman united atom force field in SYBYL (Tripos Inc.) to ensure acceptable geometry and to relieve short contacts. The overall fit of the sequence to the template was checked using Verify $3 \mathrm{D}^{22}$ The copies of modeled tertiary structures were assembled to form a hexameric quaternary assembly on the basis of the hexameric template (1s3s). This modeled quaternary structure was energy-minimized using SYBYL. ${ }^{22}$ The interfacial residues between the monomers were extracted using the Contacts of Structural Units program $^{22}$ and the crucial residues were short listed by manual inspection and used for further analysis.

Labeling of mutated missense residues in the structural model of spastin

We used a previously generated structural model of spastin, ${ }^{22}$ for labeling of the missense mutations identified in the AAA domain in our HSP cohort. In brief, the tertiary structure of the ATPase domain of spastin was modeled on the basis of the tertiary structures of two templates (PDB codes: 1xwi and 1s3s) and the quaternary structure was modeled on the basis of the hexameric template (1s3s). The consensus sequence/motifs in the AAA domain of spastin were structurally classified as active site, pore loop, protomer interacting and other residues and labeled as colored ribbons in the modeled tertiary structure. The novel spastin missense mutations identified in this study were labeled as colored space-fill structures in tertiary and quaternary structures using RasWin Molecular Graphics Version 2.7.3. (http://www.rasmol.org/).

The models of spastin are deposited in Protein Model Data Base (http://mi.caspur.it/PMDB/), which can be downloaded as PDB files (PDB codes: PM0074982 and PM0074984). The amino-acid residues in the spastin model are numbered from 1-286 aa, which corresponds to $331-$ 616 aa of the full-length spastin isoform. To determine in which functional/structural group (active site, pore loop structure, protomer interface residues and other mutations) of spastin a novel sequence variant can be cataloged, the mutated residue can be labeled by using RasWin Molecular Graphics Version 2.7.3 program.

\section{Results}

Detection of SPAST mutations in the HSP cases by sequencing and MLPA analysis

A total of 200 DNA samples of unrelated HSP individuals/ families were first screened for mutations in the SPAST gene by sequencing all the 17 exons of the gene, which led to the identification of $51(25.5 \%)$ heterozygous mutations (Table 1). Next, to detect SPAST deletion, we performed MLPA analysis in the 149 HSP cases, which were identified as SPAST negative through sequence analysis. By MLPA analysis, we identified six (three of which represented novel mutations) additional large heterozygous deletions in the SPAST gene, which accounts for $4 \%$ of the 149 HSP cases (Table 1). In our screen, 47 different mutations were detected and 29 of these mutations were novel (Table 1 ). None of the 29 identified novel mutations in our study were found in the 100 control chromosomes. In the analyzed HSP cohort, the mutation rate in the SPAST gene in pure HSP was $29.4 \%(32 / 109)$, in complex HSP it was $21.7 \%(5 / 23)$ and in cases of unknown clinical course the proportion was $29.4 \%(20 / 68)$ (Table S1). Furthermore, in familial HSP we observed a mutation frequency of $36.4 \%$ $(36 / 99)$, in sporadic HSP, it was $6.5 \%(3 / 46)$ and in HSP cases with unknown inheritance pattern, we detected a mutation rate of $32.7 \%$ (18/55) ((Table S1), Note: Table S1 S4 and Figure S1 are available as (online Supplementary Information)y.

Mutational spectrum and cluster regions in spastin The distribution analysis of the 26 novel mutations (excluding the gross deletions) along the structural domains of spastin revealed that $22(85 \%)$ mutations are localized in the conserved AAA domain, two (8\%) mutations were in the MIT domain (Figure 1a). Owing to this skewed spectrum of mutations in the spastin, we included other spastin mutations reported in the database (http:// www.biobase.de/hgmd/pro/start.php) in our analysis. Interestingly, we could identify several regions within the structural architecture of spastin where mutations were clustered (Figure 1b). The primary region was in the AAA domain (342-599 aa), which accounts for $72.7 \%$ of identified mutations in spastin (Figure $1 \mathrm{~b}$ and Table S2). Additional secondary cluster regions, were detected in the MIT domain (116-197 aa) with 7.2\% mutations, MTBD (microtubule-binding domain; $270-328$ aa) ${ }^{30}$ with $5.1 \%$ and an N-terminal region (228-269 residues) with $7.6 \%$ mutations (Figure $1 \mathrm{~b}$ and Table S2). Overall, these four regions account for $92.7 \%$ of the mutations reported to date in spastin.

\section{Functional/structural classification of the missense} mutations

Out of the 29 novel mutations, which we identified in our screen, $10(38 \%)$ are missense mutations, which are located in the AAA domain. We attempted to classify these 10 missense mutations identified in the AAA domain into different structural/functional groups based upon a previously generated structural model of spastin (PMBD id: PM0074982 and PM0074984). ${ }^{22}$ We could consign all these missense mutations in the three dimensional space of the spastin structure into four categories namely, active site, pore loop structure, protomer interface residues and other mutations (Table S3 and Figure S1A-K).

\section{S44L polymorphism in HSP}

Co-inheritance of a disease-causing mutation and the L44 allele causes an early onset of symptoms, indicating that 
10pg Mutational spectrum in SPAST gene

Table 1 List of mutations identified in the SPAST gene in our HSP cohort

\begin{tabular}{|c|c|c|c|c|c|c|c|c|c|}
\hline No. & Exon/Intron & Family no. & Type of mutation & $C D N A$ & Protein & $F S$ & $\begin{array}{c}\text { Onset of } \\
\text { phenotype }\end{array}$ & Pure/complex & $\begin{array}{c}\text { Referencel } \\
\text { novel }\end{array}$ \\
\hline 1 & Ex 1 & 24227 & Nonsense & c. $373 G>T$ & p.Glu125Term & $\mathrm{F}$ & $>35$ & Pure & 11 \\
\hline 2 & Ex 2 & 25942 & Nonsense & C. $499 \mathrm{C}>\mathrm{T}$ & p.Gln167Term & $\mathrm{s}$ & $>35$ & Pure & Novel \\
\hline 3 & Ex 3 & 24283 & Insertion & c.549_550insT & p.Asn1 84Term & $\mathrm{F}$ & $<35$ & Pure & Novel \\
\hline 4 & Ex 5 & 21987 & Deletion & c.692 delC & $\begin{array}{l}\text { p.Ala231Valfs } \\
\text { Term239 }\end{array}$ & $?$ & $?$ & $?$ & Novel \\
\hline 5 & Ex 5 & 19583 & Deletion & c.839_840delAG & $\begin{array}{l}\text { p.G } \ln 280 \text { Argfs } \\
\text { Term } 289\end{array}$ & $\mathrm{~F}$ & $<35$ & Pure & 12 \\
\hline 6 & Ex 5 & 28146 & Splice & $c .870 \mathrm{G}>\mathrm{A}$ & Unknown & $?$ & $?$ & $?$ & Novel \\
\hline 7 & Int 5 & 25961 & Splice & c. $870+1 G>T$ & Unknown & $?$ & $?$ & $?$ & Novel \\
\hline 8 & Ex 6 & 24295 & Insertion & c.981_982insAT & p.lle328llefs & $\mathrm{F}$ & $<35$ & Complicated & Novel \\
\hline 9 & Ex 7 & 21937 & Missense & c. $1067 \mathrm{~A}>\mathrm{G}$ & p.Glu356Gly & $?$ & $<10$ & ? & 6 \\
\hline 10 & Ex 7 & 21935 & Missense & c. $1081 \mathrm{C}>\mathrm{T}$ & p.Pro361Ser & $\mathrm{F}$ & $<35$ & Pure & Novel \\
\hline 11 & Int 7 & 21971 & Splice/deletion & c.1099-3_1099-1delTAG & Unknown & $\mathrm{F}$ & $>35$ & Pure & Novel \\
\hline 12 & Ex 8 & 21977 & Deletion & c.1101_1103delGTT & p.Leu367del & $\mathrm{F}$ & $>35$ & Pure & Novel \\
\hline 13 & Ex 8 & 25902 & Deletion & c.1101_1103delGTT & p.Leu367del & $\mathrm{F}$ & $<10$ & Pure & Novel (2) \\
\hline 14 & Ex 8 & 24218 & Insertion & c.1115_1116insc & $\begin{array}{l}\text { p.Arg372Argfs } \\
\text { Term393 }\end{array}$ & $?$ & $?$ & $?$ & Novel \\
\hline 15 & Ex 8 & 25945 & Missense & c. $1121 C>G$ & p.Pro374Arg & $\mathrm{F}$ & $<10$ & $?$ & Novel \\
\hline 16 & Ex 8 & 25946 & Missense & c. $1154 \mathrm{G}>\mathrm{A}$ & p.Gly385Glu & 5 & $>35$ & Pure & Novel \\
\hline 17 & Int 8 & 24292 & Splice & c. $1174-1 \mathrm{G}>\mathrm{T}$ & Unknown & $\mathrm{F}$ & $<35$ & Pure & Novel \\
\hline 18 & Ex 9 & 21938 & Missense & c. $1196 \mathrm{C}>\mathrm{T}$ & p.Ser399Leu & $\mathrm{F}$ & $?$ & $?$ & 23 \\
\hline 19 & Ex 9 & 24224 & Missense & c. $1196 \mathrm{C}>\mathrm{T}$ & p.Ser399Leu & $?$ & $?$ & $?$ & 23 \\
\hline 20 & Ex 9 & 19576 & Deletion & c. $1202 \mathrm{de} \mid \mathrm{C}$ & $\begin{array}{l}\text { p.Ala401Gluf- } \\
\text { sTerm } 406\end{array}$ & $?$ & $?$ & $?$ & Novel \\
\hline 21 & Ex 9 & 24286 & Deletion & c.1215_1219delTATAA & $\begin{array}{l}\text { p.Asn405Lysf- } \\
\text { sTerm440 }\end{array}$ & $s$ & $>35$ & Pure & 8 \\
\hline 22 & Ex9 & 24268 & Missense & c. $1216 \mathrm{~A}>\mathrm{G}$ & p.lle406 Val & $\mathrm{F}$ & $<35$ & Pure & 24 \\
\hline 23 & Ex 9 & 21901 & Deletion & c. $1245 \mathrm{de} / \mathrm{C}$ & p.Tyr415Term & $s$ & $>35$ & Pure & Novel \\
\hline 24 & Int 9 & 24248 & Splice & c. $1245+1 \mathrm{G}>\mathrm{T}$ & Unknown & $\mathrm{F}$ & $<10$ & Pure & \\
\hline 25 & Ex 10 & 24231 & Missense & c. $1250 \mathrm{G}>\mathrm{A}$ & p.Gly417Glu & $F$ & $<35$ & $\begin{array}{l}\text { Complicated } \\
\text { (cognitive }\end{array}$ & Novel \\
\hline 26 & Ex 10 & 19582 & Missense & c. $1280 \mathrm{~T}>\mathrm{G}$ & p.Phe427Cys & $\mathrm{F}$ & $>35$ & Pure & Novel \\
\hline 27 & Ex 10 & 24233 & Deletion & c. $1281 \mathrm{delT}$ & $\begin{array}{l}\text { p.Phe427Leufs } \\
\text { Term437 }\end{array}$ & $?$ & $?$ & $?$ & 26 \\
\hline 28 & Ex 10 & 24212 & Nonsense & c. $1291 \mathrm{C}>\mathrm{T}$ & p.Arg431Term & $\mathrm{F}$ & $>35$ & Pure & 8 \\
\hline 29 & Ex 11 & 19593 & Missense & c. $1339 \mathrm{~T}>\mathrm{G}$ & p.Leu447Val & $\mathrm{F}$ & $>35$ & Pure & Novel \\
\hline 30 & Ex 11 & 21214 & Missense & c. $1378 . \mathrm{C}>\mathrm{T}$ & p.Arg460Cys & $\mathrm{F}$ & $>35$ & $\begin{array}{c}\text { Complicated } \\
\text { (polyneuro-pathay) }\end{array}$ & 38 \\
\hline 31 & Ex 11 & 24222 & Missense & c. $1378 \mathrm{C}>\mathrm{T}$ & p.Arg460Cys & $?$ & $<10$ & $?$ & \\
\hline 32 & Ex 11 & 24285 & Missense & c. $1378 \mathrm{C}>\mathrm{T}$ & p.R460C & $\mathrm{F}$ & $<35$ & Pure & 27 \\
\hline 33 & Ex 11 & 24228 & Missense & c. $1379 G>A$ & p.Arg460Cys & $\mathrm{F}$ & $<35$ & Pure & Novel \\
\hline 34 & Ex 12 & 25910 & Nonsense & c. $1417 \mathrm{C}>\mathrm{T}$ & p.Arg $460 \mathrm{His}$ & $\mathrm{F}$ & $<10$ & $\begin{array}{c}\text { Autonomic nervous } \\
\text { system }\end{array}$ & Novel \\
\hline 35 & Ex 12 & 24255 & Insertion & c. 1462 1463insTA & p.Gin473Term & $\mathrm{F}$ & $>35$ & Pure & Novel \\
\hline 36 & Ex 13 & 25923 & Missense & c. $1495 \mathrm{C}>\mathrm{T}$ & $\begin{array}{l}\text { p.Arg488llef- } \\
\text { sTerm530 }\end{array}$ & $\mathrm{F}$ & $<10$ & Pure & \\
\hline 37 & Ex 13 & 21929 & Missense & c. $1496 \mathrm{G}>\mathrm{A}$ & p.Arg499Cys & $\mathrm{F}$ & $<10$ & Trunk-ataxia & 28 \\
\hline 38 & Ex 13 & 19598 & Missense & c. $1507 \mathrm{C}>\mathrm{T}$ & p.Arg $499 \mathrm{His}$ & $?$ & ? & $?$ & 14 \\
\hline 49 & Ex 14 & 21900 & Missense & c. $1540 \mathrm{~A}>\mathrm{G}$ & p.Arg503Trp & $\mathrm{F}$ & $?$ & $?$ & Novel \\
\hline 40 & Ex 14 & 21985 & Missense & c. $1540 \mathrm{~A}>\mathrm{G}$ & p.Arg $514 G \mid y$ & $\mathrm{~F}$ & $>35$ & $?$ & Novel (2) \\
\hline 41 & Ex 15 & 24230 & Insertion & c. 1649 1650insCCTAAC & p.Arg514Gly & $\mathrm{F}$ & $<35$ & Pure & Novel \\
\hline 42 & Ex 15 & 19591 & Missense & c. $1664 \bar{A}>G$ & $\begin{array}{l}\text { p. } 5505551 \text { in- } \\
\text { sLeuThr }\end{array}$ & $\mathrm{F}$ & $<35$ & Pure & Novel \\
\hline 43 & Ex 15 & 25941 & Missense & c. $1670 \mathrm{C}>\mathrm{T}$ & p.Asp555Gly & $\mathrm{F}$ & $<35$ & Pure & Novel \\
\hline 44 & Ex 15 & 21920 & Nonsense & c. $1684 \mathrm{C}>\mathrm{T}$ & p.Ala557Val & $?$ & $?$ & $?$ & 8 \\
\hline 45 & Ex 15 & 21967 & Nonsense & c. $1684 C>T$ & p.Arg562Term & $?$ & $>35$ & Pure & 8 \\
\hline 46 & Ex 15 & 21974 & Nonsense & c. $1684 \mathrm{C}>\mathrm{T}$ & p.Arg562Term & $\mathrm{F}$ & $>35$ & Pure & 8 \\
\hline 47 & Ex 15 & 24201 & Nonsense & c. $1684 C>T$ & p.Arg562Term & $\mathrm{F}$ & $<35$ & Pure & 8 \\
\hline 48 & Ex 15 & 25912 & Nonsense & c. $1684 \mathrm{C}>\mathrm{T}$ & p.Arg562Term & $\mathrm{F}$ & $>35$ & Pure & 8 \\
\hline 49 & Ex 16 & 19594 & Nonsense & c. $1702 \mathrm{C}>\mathrm{T}$ & p.Arg562Term & $?$ & $?$ & $?$ & Novel \\
\hline 50 & Ex 17 & 19597 & Missense & c. $1821 G>C$ & p.Gln568Term & $?$ & $?$ & $?$ & 13 \\
\hline 51 & Ex 17 & 25936 & Missense & c. $1821 G>C$ & p.Trp607Cys & $\mathrm{F}$ & $<35$ & Pure & 13 \\
\hline 52 & Ex $1-E \times 3$ & 24278 & Exon deletion & c. $1-? 682+? \mathrm{del}$ & Unknown & $?$ & $?$ & $?$ & 19 \\
\hline 53 & Ex 2-Ex9 & 21976 & Exon deletion & c. $41 \overline{6}-?, 1493+$ del & Unknown & $\mathrm{F}$ & $<35$ & Pure & Novel \\
\hline 54 & Ex 8 & 21968 & Exon deletion & c.1099-?_1173+?del & Unknown & $\mathrm{F}$ & $<10$ & Pure & Novel \\
\hline 55 & Ex $9-\operatorname{Ex} 17$ & 21940 & Exon deletion & c. $1174-?-1851+? \mathrm{del}$ & Unknown & $\mathrm{F}$ & $>35$ & Pure & Novel \\
\hline 56 & $E \times 2-E \times 16$ & 24270 & Exon deletion & c.416-? $1728+$ ?del & Unknown & $\mathrm{F}$ & $>35$ & Pure & 29 \\
\hline 57 & $\mathrm{E} \times 17$ & 24281 & Exon deletion & c.1729-? $18511 ? \mathrm{del}$ & Unknown & $?$ & $?$ & $?$ & 19 \\
\hline
\end{tabular}

Note: F, Familial; $S_{r}$ Sporadic. 
a

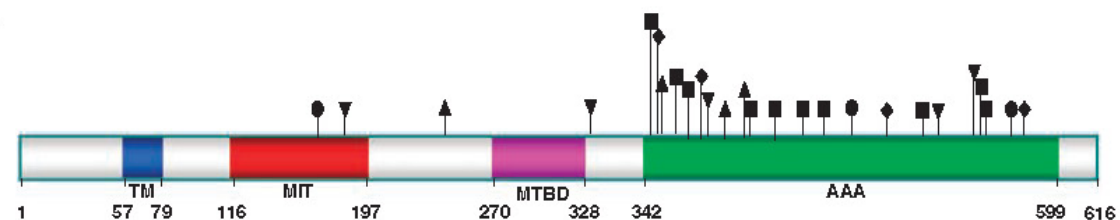

b

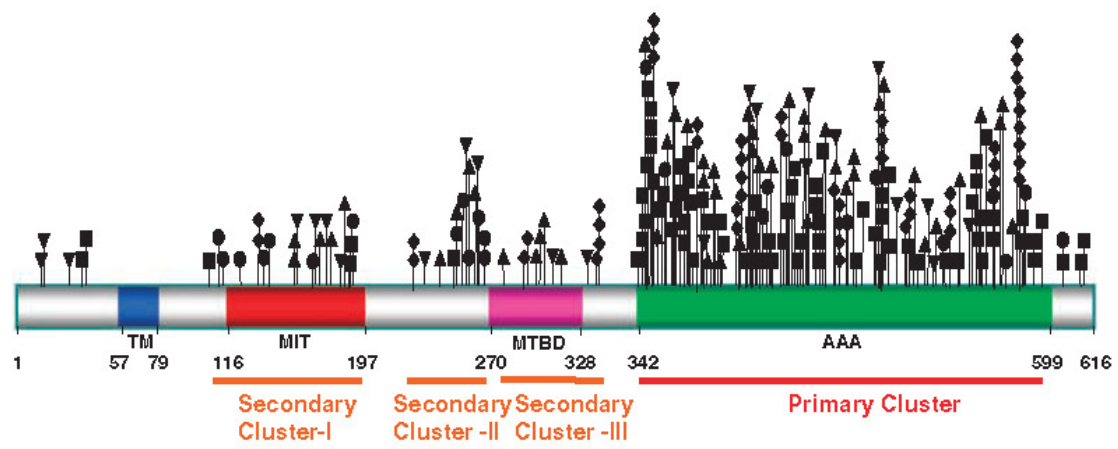

- Missense - Nonsense - Splice site $\quad$ Insertion $\Delta$ Deletion

TM - Transmembrane Domain; MIT - Microtubule Interacting and Trafficking Domain

MTBD - Microtubule Binding Domain; AAA - ATPase Associated with Various Cellular Activities Domain

Figure 1 Schematic diagram representing the structural domains of the spastin protein (616 amino acids) and showing the localization of the identified mutations. The different domains are highlighted with different colors and different kinds of mutations are marked with different symbols as summarized on the left at the bottom of the figure. (a) Representation of 26 novel mutations identified in our study. Twenty-tuvo out s 26 mas spastin protein. The primary hot spot region is indicated as a red bar in the AAA domain. Three secondary hot spot regions are shown as orange bars below the spastin structure. Note: Three novel gross deletions are not included for representation; also gross deletions are excluded for distribution analysis.

the L44 allele is a genetic modifier of the HSP disease. ${ }^{10,31}$ In our cohort of $200 \mathrm{HSP}$ patients, the S44L variant was identified in six unrelated HSP cases in heterozygous state, therefore the incidence of the L44 allele in our cohort is $1.5 \%$. In addition, in two HSP individuals, we detected a second mutation in SPAST apart from the L44 allele (Table S4).

Putative genotype-phenotype correlations

To determine whether the spastin missense mutations have a different pathomechanism in contrast to other mutation types is to examine a correlation between mutation types and clinical features, such as age at onset of the symptoms. We therefore grouped the 57 identified mutations in our HSP cohort into two groups: the missense mutations (23) and the other types of mutations (34). We placed the number of identified mutations into two categories based upon age at onset of the symptoms, namely, onset before/ at 35 years $(\leq 35)$ and after 35 years $(>35)$ as represented in
Table 2 The proportions of missense and other types of mutations in different age groups, pure/complex and familial/sporadic cases of HSP

\begin{tabular}{lccc}
\hline & Missense mutations & Other mutations & All mutations \\
\hline & 23 & 34 & 57 \\
$<35$ years & 13 & 13 & 26 \\
$>35$ years & 3 & 10 & 13 \\
Unknown & 7 & 11 & 18 \\
Pure & 11 & 21 & 32 \\
Complex & 3 & 2 & 5 \\
Unknown & 9 & 11 & 20 \\
Familial & 16 & 20 & 36 \\
5poradic & 1 & 2 & 3 \\
Unknown & 6 & 12 & 18 \\
\hline
\end{tabular}

Table 2. In the $\leq 35$ age group, we observed an equal proportion of missense mutations $(13 / 26 ; 50 \%)$ and other types of mutations $(13 / 26 ; 50 \%)$ (Table 2 ). In the $>35$ age 
group, we detected a higher fraction of other mutation types, $(10 / 13 ; 76.9 \%)$ as compared with missense mutations $(3 / 13 ; 23 \%)$ (Table 2 ). However, statistically the differences between the proportion of missense and other mutations in $>35$ age group was not significant $(P>0.05)$. Interestingly, we noticed a skewed distribution of missense mutations between the two age groups; $\leq 35$ and $>35$ years. Therefore, we tested a null hypothesis that there is no difference in the proportion of the subjects with missense mutations between two age groups $\leq 35$ and $>35$ years, the chi-square test demonstrated that there is a significant difference $(P<0.012)$, whereas no significant difference could be detected for subjects with other mutation types $(P>0.5)$.

\section{Discussion}

In our current endeavor, we attempted to expand the mutational spectrum of SPAST. To this end, we screened for mutations in the SPAST gene in 200 HSP patients and identified 47 different mutations, out of which 29 were novel mutations. The overall frequency of SPAST mutations in our cohort was $28.5 \%$ (57/200). The mutation rate did not change significantly when we only considered pure HSP, which was $29.4 \%(32 / 109)$. Interestingly, in case of complex HSP a high mutational rate of $21.7 \%(5 / 23)$ was detected in our HSP cohort, which highlights the need to screen for the SPAST mutation in complex HSP cases. However, owing to lack of family history, we were unable to show segregation of additional symptom(s) with paraplegia, therefore, it is also possible that the complex phenotype could also be because of an independent locus other than the SPAST. The mutation detection rate in our cohort is consistent with the range of $15-44 \%$, which was observed previously in other populations. ${ }^{8-11,13}$ The frequency of mutations increased if we only considered the autosomal dominant HSP cases (36.4\%) suggesting that prevalence of SPAST mutation is higher in the familial cases. Among the sporadic cases of HSP, the frequency of mutations was $6.5 \%(3 / 46)$, which was lower than the previously reported rate of $12-18 \%{ }^{13,14}$ This discrepancy could be because of the different population type and size. Nevertheless, from a diagnostic point of view, our and other reports emphasize the need to screen for SPAST mutations in the sporadic HSP cases.

In our HSP cohort, we identified 51 mutations in the SPAST gene by direct sequencing of all the 200 HSP patients, which left 149 HSP cases in which no mutations could be detected by conventional sequencing. To determine gross deletion/insertion in the SPAST gene, we performed MLPA analysis in these 149 HSP cases and detected six additional mutations, which accounts for $4 \%$ (6/149) of remaining HSP cases. Previously, two independent studies used same SPAST-specific MLPA assay and reported a much higher proportion (18-20\%) of deletion in HSP patients. ${ }^{19,20}$ The observed disparity in the proportion of large deletions between our HSP cohort and others could be because of the divergence and ethnic variability in these cohorts. Nevertheless, our report of much lower proportion of gross deletions in the SPAST gene in the HSP patients stresses the need to perform MLPA in various HSP cohorts to determine the incidence rate of gross deletions in worldwide HSP populations.

It is remarkable that $22(85 \%)$ out of the 26 nove mutations (excluding the gross deletions) were located in the AAA domain of spastin. Previously, our group reported clustering of mutations in the AAA domain of spastin in a German HSP cohort ${ }^{12}$ and this clustering in AAA domain was also observed in several other HSP cohorts. ${ }^{6-10}$ Moreover, the distribution of mutations reported in the database over the structural domains of spastin outside the AAA domain were also not uniform; rather they were concentrated in certain regions of the protein, which constituted various functional domains, such as MIT and MTBD. In prior studies, exon 1 , exon 5 and exon 8 of SPAST was recognized as hot spot regions; $;^{32-34}$ however, no correlation to functional domain of spastin was implicated. Overall, it appears that different functional domains of spastin are target regions for mutations, which underlines their functional significance. Identification of these cluster regions highlights the need to set these regions as priority in the molecular diagnostic screens.

Beside a few exceptions, almost all the missense mutations in spastin are located in the AAA domain and recent studies suggest that these missense mutations might exert a dominant-negative effect on the molecular function of spastin. ${ }^{35,36}$ Utilization of a recently modeled structure of the AAA domain of spastin, ${ }^{22}$ as a framework, enabled us to classify the identified missense mutations from our cohort into different functional groups such as active site, protomer-protomer interaction, pore loop and unknown structural group of mutations. The functional categorization of the novel missense mutations, based upon the structural model of spastin will enable us in future to predict any identified sequence variant in a HSPSPAST patient as disease-causing mutation with greater level of certainty. These structural predictions of various functional classes of missense mutations need to be validated by biochemical/cellular studies and data from the structural model should be interpreted with cautiousness. However, in a recent study, we could validate at the cellular level the functional effect of two sequence variants (E442Q and R499C) of spastin, which were predicted as active site mutations from the structural model of spastin. ${ }^{22}$

The rare $\mathrm{S} 44 \mathrm{~L}$ polymorphism is considered to act as a modifier of the HSP phenotype. ${ }^{10,31,37}$ S44L is not considered as a susceptibility factor for HSP because its 
frequency rate is similar in HSP patients and controls. ${ }^{14}$ In our study, we could not ascertain the role of $\$ 44 \mathrm{~L}$ (heterozygous state alone) on manifestation of HSP. It is possible that the patients heterozygous for S44L might have another mutation in spastin, which could not be identified by our screen or might have a mutation in a different HSP gene.

No apparent genotype-phenotype correlation is evident among missense mutations and other SPAST mutations. ${ }^{8,14,38}$ Although several studies indicated that missense mutation might act in a dominant-negative fashion in contrast to other mutations, which lead to a loss of function. To determine, whether missense mutation leads to early onset of HSP, we assorted our HSP cohort into two different groups based upon AAO ( $\leq 35$ and $>35$ years). The rational behind sorting our HSP cohort into these two age groups was derived from Harding's classification of HSP patients into two distinct groups, early age onset $(\leq 35$ years) and late age onset ( $>35$ years). ${ }^{39}$ This AAO $(\leq 35$ and $>35$ years) classification was also used by Fonknechten and coworkers for determination of genotype-phenotype correlation. ${ }^{8}$ We observed an obvious difference in the proportion of mutations between the missense group as compared with the other types of mutations in age group of $>35$ years. However, the observed difference was not statistically significant $(P>0.05)$ because of a very small sample size. Remarkably, we could reject a null hypothesis that there is no difference in the proportion of subjects for missense mutations between two age groups, $\leq 35$ and $>35$ years, which was statistically significant $(P<0.0124)$. Our data show a tentative genotype-phenotype correlation and suggest that in case of missense mutations the onset of phenotype is earlier. Owing to a small sample size, this correlation between AAO and missense mutation should be interpreted with discretion. Previously, early AAO in patients with missense mutation was also reported; however, this study only accounted for two missense mutations out of a total five mutations. ${ }^{40}$ Moreover, in a meta-analysis ${ }^{38}$ no significant correlation between AAO and mutational class was evident, but one limitation of this study was the sample size. Nevertheless, these different pathomechanism modes, such as loss of function and dominant-negative function for different classes/types of spastin mutations need to be carefully resolved by experimental means; otherwise there will be repercussions on the likely success of any therapeutical approach devised for spastin-associated HSP.

\section{Acknowledgements}

We thank the HSP patients/families for their participation in this study, B Brandt for excellent technical assistance, $P$ Grzmil for statistical analysis and $W$ Engel for critical comments/reading of the paper. This work was funded partly by a Tom Wahlig Stiftung Grant and the Deutsche Forschungsgemeinschaft (MA 3344/2-1) Grant to $A U M$ and by the institution's internal fund.

\section{References}

1 Bruyn RPM, Scheltens P: Hereditary spastic paraparesis (Strümpell-Lorrain), Diseases of the motor system; in de Jong JMBV (ed): Handbook of Clinical Neurology. Elsevier Science Publishers: Oxford, 1991, vol 15, pp 301-318.

2 Behan WM, Maia M: Strumpell's familial spastic paraplegia: genetics and neuropathology. I Neurol Neurosurg Psychiatry 1974; 37: 8-20.

3 Schwarz GA, Liu CN: Hereditary (familial) spastic paraplegia; further clinical and pathologic observations. AMA Arch Neurol Psychiatry 1956; 75: 144-162.

4 Fink JK: The hereditary spastic paraplegias: nine genes and counting. Arch Neurol 2003; 60: 1045-1049.

5 Reid E: Science in motion: common molecular pathological themes emerge in the hereditary spastic paraplegias. J Med Genet 2003; 40: 81-86.

6 Hazan J, Fonknechten N, Mavel D et al: Spastin, a new AAA protein, is altered in the most frequent form of autosomal dominant spastic paraplegia. Nat Genet 1999; 23 . 296-303.

7 McDermott CJ, Burness CE, Kirby J et al: Clinical features of hereditary spastic paraplegia due to spastin mutation. Neurology 2006; 67: 45-51.

8 Fonknechten N, Mavel D, Byrne P et al: Spectrum of SPG4 mutations in autosomal dominant spastic paraplegia. Hum $\mathrm{Mol}$ Genet 2000; 9: 637-644

9 Hentati $\mathrm{A}$, Deng HX, Zhai $\mathrm{H}$ et al: Novel mutations in spastin gene and absence of correlation with age at onset of symptoms. Neurology 2000; 55: 1388-1390.

10 Lindsey JC, Lusher ME, McDermott CJ et al: Mutation analysis of the spastin gene (SPG4) in patients with hereditary spastic paraparesis. JMed Genet 2000; 37: 759-765.

11 Patrono $C_{t}$ Scarano $V$, Cricchi $F$ et al: Autosomal dominant hereditary spastic paraplegia: DHPLC-based mutation analysis of SPG4 reveals eleven novel mutations. Hum Mutat 2005; $25: 506$.

12 Sauter $S$, Miterski B, Klimpe $S$ et al: Mutation analysis of the spastin gene (SPG4) in patients in Germany with autosomal dominant hereditary spastic paraplegia. Hum Mutat 2002; 20: $127-132$

13 Crippa F, Panzeri C, Martinuzzi A et al: Eight novel mutations in SPG4 in a large sample of patients with hereditary spastic paraplegia. Arch Neurol 2006; 63: 750-755.

14 Depienne C, Tâllaksen C, Lephay JY et al: Spastin mutations are frequent in sporadic spastic paraparesis and their spectrum is different from that observed in familial cases. J Med Genet 2006 43: $259-265$.

15 Confalonieri F, Duguet M: A 200-amino acid ATPase module in search of a basic function. Bioessays 1995; 17: 639-650.

16 Frickey $T$, Lupas AN: Phylogenetic analysis of AAA proteins. J Struct Biol 2004; 146: 2-10.

17 Patel S, Latterich M: The AAA team: related ATPases with diverse functions. Trends Cell Biol 1998; 8: 65-71.

18 Hanson PI, Whiteheart SW: AAAt proteins: hâve engine, will work. Nat Rev Mol Cell Biol 2005; 6: 519-529.

19 Beetz C, Nygren AO, Schickel J et al: High frequency of partial SPAST deletions in autosomal dominant hereditary spastic paraplegia. Neurology 2006; 67: 1926-1930.

20 Depienne C, Fedirko E, Forlani $S$ et al: Exon deletions of SPG4 are a frequent cause of hereditary spastic paraplegia. J Med Genet 2007; 44: 281-284

21 Harding AE: Classification of the hereditary ataxias and paraplegias. Lancet 1983; 1: 1151-1155.

22 Pantakani DV, Swapna LS, Srinivasan N, Mannan AU: Spastin oligomerizes into a hexamer and the mutant spastin (E442Q) redistribute the wild-type spastin into filamentous microtubule. J Neurochem 2008; 106: 613-624.

23 Meijer IA, Hand CK, Cossette P et al: Spectrum of SPG4 mutations in a large collection of North American families with hereditary spastic paraplegia. Arch Neurol 2002; 59: 281-286. 


Mutational spectrum in SPAST gene
M Shoukier et al

24 Schickel J, Beetz C, Fronmel $C$ et al: Unexpected pathogenic mechanism of a novel mutation in the coding sequence of SPG4 (spastin). Neurology 2006; 66: 421-423.

25 Svenson IK, Ashley-Koch AE, Gaskell PC et al: Identification and expression analysis of spastin gene mutations in hereditary spastic paraplegia. Am J Hum Genet 2001; 68: 1077-1085.

26 Mead $\mathrm{SH}$, Proukakis $\mathrm{C}$, Wood $\mathrm{N}$ et al: A large family with hereditary spastic paraparesis due to a frame shift mutation of the spastin (SPG4) gene: association with multiple sclerosis in two affected siblings and epilepsy in other affected family members. J Neurol Neurosurg PSychiatry 2001; 71: 788-791.

27 Falco M, Scuderi C, Musumeci S et al: Two novel mutations in the spastin gene (SPG4) found by DHPLC mutation analysis. Neuromuscul Disord 2004; 14: 750-753.

28 Park SY, Ki CS, Kim HJ et al: Mutation analysis of SPG4 and SPG3A genes and its implication in molecular diagnosis of Korean patients with hereditary spastic paraplegia. Arch Neurol 2005; 62: $1118-1121$

29 Beetz C, Zuchner S, Ashley-Koch A et al: Linkage to a known gene but no mutation identified: comprehensive reanalysis of SPG4 HSP pedigrees reveals large deletions as the sole cause. Hum Mutat 2007: 28: 739-740

30 White SR, Evans KJ, Lary J, Cole JL, Lauring B: Recognition of C-terminal amino acids in tubulin by pore loops in Spastin is important for microtubule severing. I Cell Biol 2007; 176: $995-1005$.

31 Svenson IK, Kloos MT, Gaskell PC ef al: Intragenic modifiers of hereditary spastic paraplegia due to spastin gene mutations. Neurogenetics 2004; 5: 157-164.

32 McDermott CJ, Burness CE, Rao Kirby J, Shaw PJ: Further insight into HSP and spastin: severe complicated phenotypes and evidence of lower motor neurone dysfunction (Abstract number 059); Proceedings of Clinical Neurosciences, Torquay, Devon, 7-9 September 2005; neurology abstracts only. I Neurol Neurosurg Psychiatry 2006; 77: 126-142.

33 Nielsen JE, Koefoed P, Kjaergaard S, Jensen LN, Nørremølle A, Hasholt L: Prenatal diagnosis of autosomal dominant hereditary spastic paraplegia (SPG4) using direct mutation detection. Prenat Diagn 2004; 24 : $363-366$

34 Zhao GH, Tang BS, Luo Wet al: Spastin gene mutation in Chinese patients with hereditary spastic paraplegia. Zhonghua Yi Xue Yi Chuan Xue Za Zhi 2003; 20: 177-180. (article in Chinese).

35 Errico A, Ballabio A, Rugarli EI: Spastin, the protein mutated in autosomal dominant hereditary spastic paraplegia, is involved in microtubule dynamics. Hum Mol Genet 2002; 11: 153-163.

36 Evans KJ, Gomes ER, Reisenweber SM, Gundersen GG, Lauring BP: Linking axonal degeneration to microtubule remodeling by Spastin-mediated microtubule severing. I Cell Biol 2005; 168: $599-606$

37 Chinnery PF, Keers SM, Holden MJ, Ramesh V, Dalton A: Infantile hereditary spastic paraparesis due to codominant mutations in the spastin gene. Neurology 2004: 63: 710-712.

38 Yip AG, Durr A, Marchuk DA et al: Meta-analysis of age at onset in spastin-associated hereditary spastic paraplegia provides no evidence for a correlation with mutational class. J Med Genet 2003; 40: e106.

39 Harding AE: Hereditary 'pure' spastic paraplegia: a clinical and genetic study of 22 families. I Neurol Neurosurg Psychiatry 1981 44: $871-883$

40 Ivanova $\mathrm{N}$, Löfgren A, Tournev I et al: Spastin gene mutations in Bulgarian patients with hereditary spastic paraplegia. Clin Genet 2006; 70: $490-495$

Supplementary Information accompanies the paper on European Journal of Human Genetics website (http:/www.nature.com/ejhg) 


\section{Online supplementary information}

\begin{tabular}{|lll|}
\hline \multicolumn{3}{|l|}{ Table S1: Incidence rate of $S P A S T$ mutations in Hereditary spastic paraplegia (HSP) } \\
\hline & Number of cases & Percentage \\
\hline Pure HSP & $32 / 109$ & $29.4 \%$ \\
Complex HSP & $5 / 23$ & $21.7 \%$ \\
Unknown HSP & $20 / 68$ & $29.4 \%$ \\
& & \\
Familial HSP & $36 / 99$ & $36.4 \%$ \\
Sporadic HSP & $3 / 46$ & $6.5 \%$ \\
Unknown HSP & $18 / 55$ & $32.7 \%$ \\
\hline
\end{tabular}




\begin{tabular}{|c|c|c|c|c|c|c|c|c|c|}
\hline $\begin{array}{l}\text { Domain/ } \\
\text { Region }\end{array}$ & Missense & Nonsense & $\begin{array}{l}\text { Splice } \\
\text { site }\end{array}$ & Insertions & Deletions & $\begin{array}{l}\text { Small } \\
\text { indels }\end{array}$ & Total & $\begin{array}{c}\% \text { of } \\
\text { mutations }\end{array}$ & $\begin{array}{c}\% \text { of } \\
\text { mutations in } \\
\text { three major } \\
\text { domains } \\
\end{array}$ \\
\hline $\begin{array}{l}\text { N-terminus } \\
\text { (1-87 a.a) }\end{array}$ & 2 & -- & - & 3 & - & -- & 5 & 2.1 & -- \\
\hline $\begin{array}{c}\text { TM } \\
\text { (57-79 a.a) }\end{array}$ & - & - & - & - & - & -- & 0 & 0 & - \\
\hline $\begin{array}{c}\text { MIT } \\
(116-197 \text { a.a) }\end{array}$ & 2 & 5 & 2 & 3 & 5 & -- & 17 & 7.2 & \multirow{4}{*}{92.7} \\
\hline $\begin{array}{l}\text { N-terminus } \\
\text { (228-269 a.a) }\end{array}$ & 1 & 7 & 2 & 3 & 5 & -- & 18 & 7.6 & \\
\hline $\begin{array}{c}\text { MTBD } \\
(270-328 \text { a.a) }\end{array}$ & -- & -- & 5 & 1 & 5 & 1 & 12 & 5.1 & \\
\hline$\underset{(342-599 \text { a.a) }}{\mathrm{AAA}}$ & $71^{a}$ & 11 & 38 & 13 & 37 & 1 & 171 & 72.7 & \\
\hline $\begin{array}{r}\text { C-terminus } \\
(600-616 \text { a.a) }\end{array}$ & 3 & 1 & - & -- & -- & -- & 4 & 1.7 & -- \\
\hline $\begin{array}{l}\text { N-terminus* } \\
\text { (others) }\end{array}$ & 1 & 2 & 3 & 1 & 1 & -- & 8 & 3.4 & -- \\
\hline Total & 80 & 26 & 50 & 24 & 53 & 2 & $235 / 235$ & - & - \\
\hline $\begin{array}{c}\% \text { of } \\
\text { mutations }\end{array}$ & 34.0 & 11.0 & 21.2 & 10.2 & 22.5 & 0.8 & - & - & - \\
\hline \multicolumn{10}{|c|}{ Q.2, amino acide; Indelg, insertion-deletion. } \\
\hline \multicolumn{10}{|c|}{ 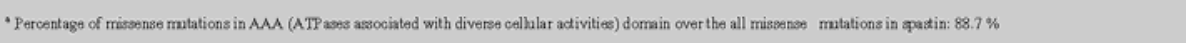 } \\
\hline \multicolumn{10}{|c|}{ 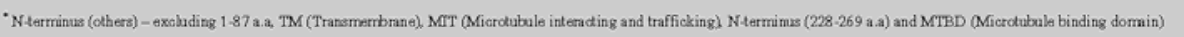 } \\
\hline \multicolumn{10}{|c|}{ Note: Groses deletions are nd inchdod in this distribution analysis } \\
\hline
\end{tabular}




\begin{tabular}{|c|c|c|}
\hline Active Site Motif & Consensus sequence & Disease associated mutations \\
\hline Walker A & ${ }^{382}$ GPPGNGKTM $^{390}$ & G385E \\
\hline Walker B & ${ }^{441} \mathrm{DEVD}^{444}$ & -- \\
\hline SRH & ${ }^{480}$ VLVMGATNRPQELDEAVLRR $^{499}$ & -.- \\
\hline $\begin{array}{l}\text { Pore Loop Residues } \\
\text { Pore loop } 1\end{array}$ & ${ }^{408}$ AASLTSKYVGEGEK $^{421}$ & G417E \\
\hline Pore loop 2 & ${ }^{445}$ SLLCERREGEHDAS ${ }^{458}$ & L $447 \mathrm{~V}$ \\
\hline Key Protomer Inter & $\begin{array}{l}\text { Residues } \\
\text { E356, I357, I359, L360, L367, } \\
\text { F368, R372, P384, G385, K388, } \\
\text { T412, S413, K414, T415, D441, } \\
\text { E442, R460, L466, N487, A495, } \\
\text { R498, R499, K502, Q525, S547, } \\
\text { D555, A557, L558, I561, R562, } \\
\text { L564, R578, S595, T615, V616 }\end{array}$ & $\begin{array}{l}\text { R } 460 \mathrm{H}, \mathrm{D} 555 \mathrm{G} \\
\text { A557V }\end{array}$ \\
\hline Other mutations & & $\begin{array}{l}\text { P361S, P374R } \\
\text { F427C, R514G }\end{array}$ \\
\hline
\end{tabular}




\begin{tabular}{|c|c|c|c|c|c|c|c|}
\hline $\begin{array}{l}\text { Group } \\
\text { Number }\end{array}$ & $\begin{array}{c}\text { DNA } \\
\text { Number }\end{array}$ & Exon & cDNA & Protein & $\begin{array}{l}\text { Age at } \\
\text { Onset }\end{array}$ & Familial & Symptoms \\
\hline \multirow[t]{2}{*}{1} & 25910 & $\begin{array}{l}\text { Exon } 1+ \\
\text { Exon12 }\end{array}$ & $\begin{array}{l}{[\mathrm{c} .131 \mathrm{C}>\mathrm{T}]+} \\
{[\mathrm{c} .1417 \mathrm{C}>\mathrm{T}]}\end{array}$ & $\begin{array}{l}{[\mathrm{S} 44 \mathrm{~L}]+} \\
{[\mathrm{p} . \mathrm{Q} 473 \mathrm{X}]}\end{array}$ & $<10$ & Yes & \multirow[t]{2}{*}{$\begin{array}{l}\text { Abnormal autonomic } \\
\text { nervous system, increased } \\
\text { sweating of hands and feet }\end{array}$} \\
\hline & 19598 & $\begin{array}{l}\text { Exon } 1+ \\
\text { Exon13 }\end{array}$ & $\begin{array}{l}{[c .131 \mathrm{C}>\mathrm{T}]+} \\
{[\mathrm{c} .1507 \mathrm{C}>\mathrm{T}]}\end{array}$ & $\begin{array}{l}{[\mathrm{S} 44 \mathrm{~L}]+} \\
{[\mathrm{p} \cdot \mathrm{R} 503 \mathrm{~W}]}\end{array}$ & $<60$ & $?$ & \\
\hline \multirow[t]{2}{*}{2} & 21938 & Exon 9 & c. $1196 \mathrm{C}>\mathrm{T}$ & p.S399L & $>10$ & Yes & Pure \\
\hline & 24224 & Exon 9 & c. $1196 \mathrm{C}>\mathrm{T}$ & p.S399L & $<60$ & Yes & $?$ \\
\hline \multirow[t]{4}{*}{3} & 21214 & Exon 11 & c. $1378 \mathrm{C}>\mathrm{T}$ & p.R $460 \mathrm{C}$ & $<60$ & Yes & Pure \\
\hline & 24222 & Exon 11 & c. $1378 \mathrm{C}>\mathrm{T}$ & p. R $460 \mathrm{C}$ & $<60$ & Yes & Polyneuropathy \\
\hline & 24228 & Exon 11 & c. $1379 \mathrm{G}>\mathrm{A}$ & p. $\mathrm{R} 460 \mathrm{H}$ & $<60$ & Yes & Pure \\
\hline & 24285 & Exon 11 & c. $1378 \mathrm{C}>\mathrm{T}$ & p. R460C & $<35$ & Yes & Pure \\
\hline \multirow[t]{2}{*}{4} & 21929 & Exon 13 & c. $1496 \mathrm{G}>\mathrm{A}$ & p. R499H & $<10$ & Yes & Trunk-ataxia \\
\hline & 25923 & Exon 13 & c. $1495 \mathrm{C}>\mathrm{T}$ & p. R499C & $<10$ & Yes & Pure \\
\hline \multirow[t]{2}{*}{5} & 21900 & Exon 14 & $1665 \mathrm{~A}>\mathrm{G}$ & p. R514G & $<60$ & Yes & $?$ \\
\hline & 21985 & Exon 14 & $1665 \mathrm{~A}>\mathrm{G}$ & p. R514G & $?$ & $?$ & $?$ \\
\hline \multirow[t]{5}{*}{6} & 21920 & Exon 15 & c. $1684 \mathrm{C}>\mathrm{T}$ & p. R562X & $?$ & $?$ & $?$ \\
\hline & 21976 & Exon 15 & c. $1684 \mathrm{C}>\mathrm{T}$ & p. R562X & $?$ & $?$ & $?$ \\
\hline & 21974 & Exon 15 & c. $1684 \mathrm{C}>\mathrm{T}$ & p. R562X & $<60$ & Yes & Pure \\
\hline & 24201 & Exon 15 & c. $1684 \mathrm{C}>\mathrm{T}$ & p. R562X & $<35$ & Yes & Pure \\
\hline & 25912 & Exon 15 & c. $1684 \mathrm{C}>\mathrm{T}$ & p. R562X & $<60$ & Yes & Pure \\
\hline \multirow[t]{2}{*}{7} & 19597 & Exon17 & c. $1821 \mathrm{G}>\mathrm{C}$ & p.W607C & $?$ & $?$ & $?$ \\
\hline & 25936 & Exon 17 & $\mathrm{c} .1821 \mathrm{G}>\mathrm{C}$ & p.W607C & $<35$ & Yes & Pure \\
\hline
\end{tabular}




\section{Legend for figure}

Figure S1: Structural categorization of novel missense mutations identified in our HSP cohort. The missense mutations identified were categorized into four classes based upon the model of the AAA domain of spastin. The first category consists of the active site mutations (A-C), the consensus amino acid residues are highlighted in red in the tertiary structure of spastin (A), the position of the mutation indicated as a red ball and stick in the tertiary and quaternary structure of spastin (B-C). The conserved pore loop residues are marked as green in the spastin structure (D), the HSP mutated residues categorized as pore loop mutations are depicted as a green ball and stick in the spastin monomer and hexamer (E-F). The key interacting residues between protomers required for oligomerization are shown in blue color in the tertiary structure of spastin $(G)$. Furthermore, the identified HSP mutations in this group are also shown in the spastin monomer and hexamer (H-I). The HSP mutations which could not be classified in one of the above groups were designated as other class of mutations. Labeling of these mutated residues in the modeled spastin structure revealed that they can further be grouped in three clusters which are labeled in magenta, orange and yellow (J-K). 
Figure S1
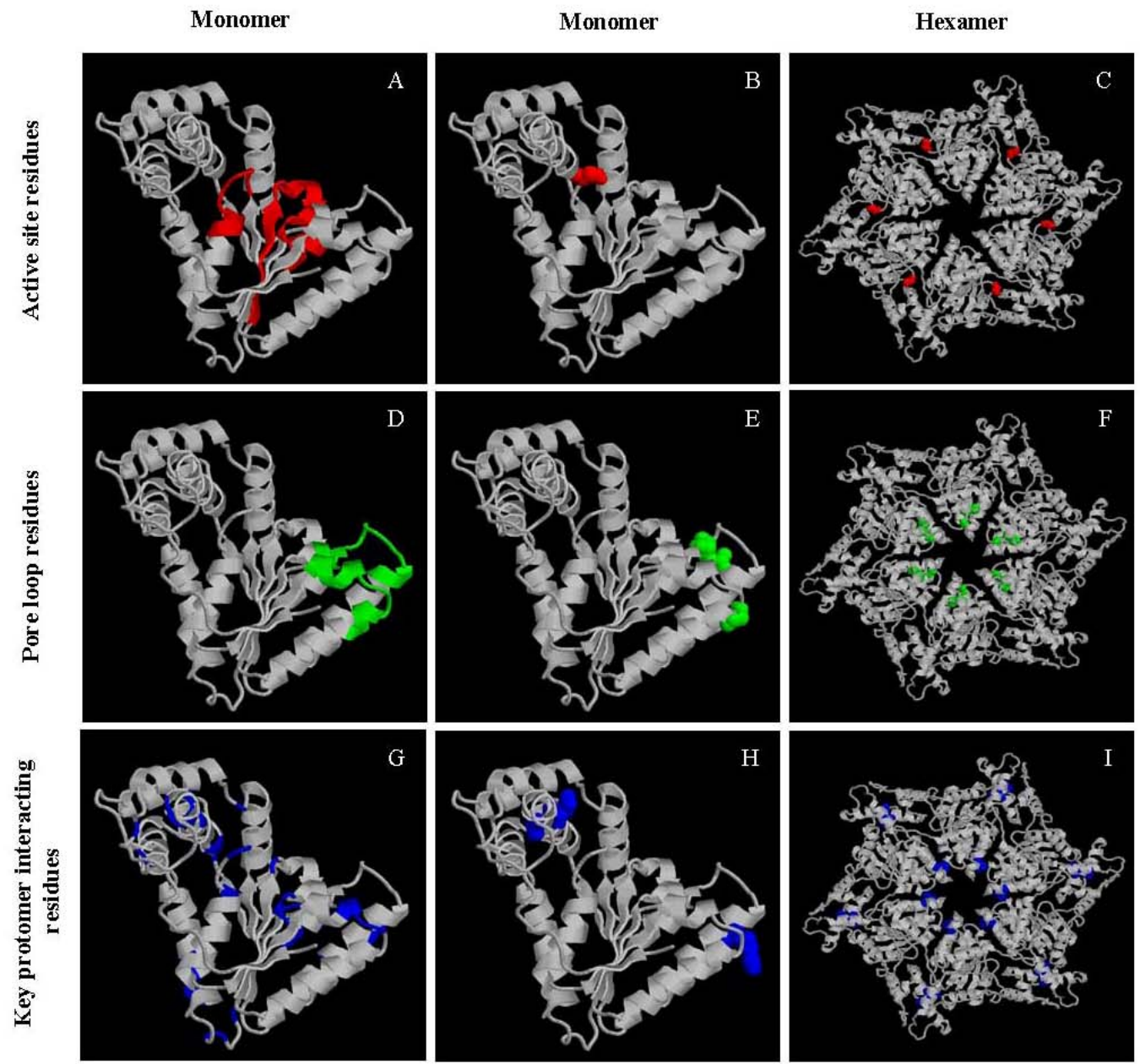

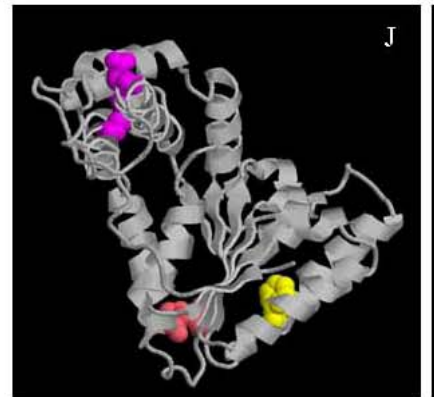

Mutated residues

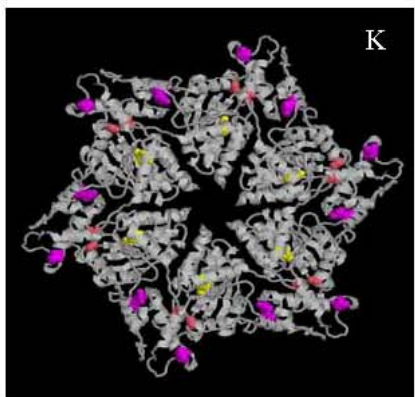

Mutated residues 


\subsection{Publikation II}

Evaluating the effect of spastin splice mutations by quantitative allele-specific expression assay.

DOI: 10.1111/j.1468-1331.2010.03079.x

\section{Der Status der Publikation:}

Die Arbeit wurde am 26.03.2010 von der Zeitschrift European Journal of Neurology zum Druck angenommen. Der 5 years Journal Impact Factor ist 3.020 (2009).

\section{Die Namen der Koautoren:}

Sven Klimpe, Arne Zibat, Ulrich Zechner Brigitte Wellek, Moneef Shoukier, Simone M Sauter, Krishna D.V. Pantakani und Ashraf U. Mannan.

\section{Der Anteil der Koautoren an dem Gesamtprojekt:}

Sven Klimpe: Die Rekrutierung der Patienten, die Durchführung der Klinischneurologischen Untersuchung und die Abfassung des Manuskripts.

Arne Zibat: Die Durchführung des quantitativen Allel-spezifischen Expressionsassays Ulrich Zechner und Brigitte Wellek: Die RNA-Präparation

Moneef Shoukier: Die SPG4-Mutationsanalyse sowie die Beteiligung an der Abfassung des Manuskripts

Simone M Sauter: Die SPG4-Mutationsanalyse

Krishna D.V. Pantakani : Die Durchführung des Reversen Transkriptase-PolymeraseKettenreaktion- Assays

Ashraf U. Mannan :Studiendesign und Durchsicht des Manuskripts 


\title{
Evaluating the effect of spastin splice mutations by quantitative allele-specific expression assay
}

\author{
S. Klimpe ${ }^{a *}$, A. Zibat ${ }^{b *}$, U. Zechner ${ }^{c}$ B. Wellek ${ }^{c}$, M. Shoukier ${ }^{b}$, S. M. Sauter , D. V. K. Pantakanib \\ and A. U. Mannan ${ }^{b, d}$ \\ ${ }^{a}$ Department of Neurology, University Medical Center, Johannes Gutenberg University, Mainz; ' Instiune of Human Genetics, University of \\ Goetingen, Goetingen; 'Thstitute of Human Genetics, University Medicat Center, Johanes Gutenterg University, Mainz; and

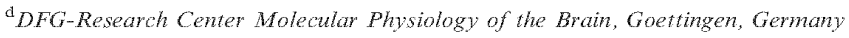

\section{Keywords:}

hypomorphic, leaky

splicing, SPAST, spastin. SPG4

Received 16 November 2009 Accepted 26 March 2010
Background: Mutations in the SPG4/SPAST gene are the most common cause for hereditary spastic paraplegia (HSP). The splice-site mutations make a significant contribution to HSP and account for $17.4 \%$ of all types of mutations and $30.8 \%$ of point mutations in the SPAST gene. However, only few studies with limited molecular approach were conducted to investigate and decipher the role of $S P A S T$ splice-site mutations in HSP.

Methods: A reverse transcriptase-polymerase chain reaction (RT-PCR) analysis and quantitative allele-specific expression assay were performed.

Results: We have characterized the consequence of two novel splice-site mutations $(c .1493+1 \mathrm{G}>\mathrm{A}$ and $c .1414-1 \mathrm{G}>\mathrm{A})$ in the SPAST gene in two different families with pure HSP. The RT-PCR analysis revealed that both spastin mutations are indeed splice-site mutations and cause skipping of exon 12. Furthermore, RT-PCR data suggested that these splice-site mutations may cause leaky splicing. By means of a quantitative allele-specific expression assay, we could confirm that both splice-site mutations cause leaky splicing, as the relative expression of the exon 12-skipped transcript was reduced $(21.1 \pm 3.6$ compared to expected $50 \%)$.

Conclusions: Our finding supports a "threshold-effect-model" for functional spastin in HSP. A higher level (78.8 $\pm 3.9 \%$ ) of functional spastin than the expected ratio of $50 \%$ owing to leaky splicing might cause late age at onset of HSP. Remarkably, we could show that a quantitative allele-specific expression assay is a simple and effective tool to evaluate the role of most types of spastin splice-site mutations in HSP.

\section{Introduction}

Hereditary spastic paraplegias (HSP) are a group of neurodegenerative disorders clinically characterized by progressive spastic paralysis in the lower limbs, which is caused by length-dependent distal degeneration of the corticospinal tract axons [1-3]. Genetically, HSP are extremely heterogeneous, which is evident from the discovery of $>42$ different loci, of which 19 responsible genes are now identified.

Despite this observed genetic heterogeneity in HSP, mutations in the SPAST/SPG4 gene (OMIM: 604277)

Correspondence A U Mannan, Institute of Human Genetics, University of Goettingen, Heinrich-Dueker-Weg 12, D-37073, Goettingen, Germany (tel.: +49551 397522; fax : + 49551399303 ; e-mail: amannan@gwdg.de)

*These authors contributed equally are the single most common cause for HSP and account for almost $\sim 40 \%$ of autosomal dominant cases, with variable frequencies depending on the ethnic origin of the selected cohort of patients [4 8 . The SPAST gene encodes for the protein spastin, a member of the AAA (ATPases associated with diverse cellular activities) family of ATPases $[9,10]$. Over 300 diferent mutations in the SPAST gene have been described to date, which are summarized in the Human Gene Mutation Database (HGMD) Professional release 2009.4 (https:/portal.biobase-international.com/hgmd/pro/all.php). The majority of the SPAST mutations are predicted to cause premature truncation of spastin either by nonsense or through frame-shift changes (splice-site alterations, deletions and insertions). The spectrum of SPAST mutations was further extended by the finding of large deletions of the entire gene or of multiple exons using a 
SPAST-specific multiplex ligation-dependent probe amplification assay $[11,12]$.

The observation of a broad mutational spectrum with the majority of SPAST mutations leading to either a dysfunctional protein or no protein suggests that the pathogenic mechanism is probably haploinsulficiency. However, several studies have advocated a "thresholdeffect-model" for spastin [13-15]. This implies that below a critical threshold level of functional (wild-type) spastin, the symptoms of HSP will emerge. However, this threshold for the dosage of functional spastin may be higher than the expected $50 \%$, as in some patient with "leaky" splice-site mutations (producing both wildtype and aberrant splice transcripts), the symptoms of HSP are still manifested. Different SPAST splice-site mutations depending upon the extent of leaky splicing may show a variable level of expression, because both wild type and aberrant transcripts will be produced from the mutated allele [13-15]. The variable level of expression in the case of splice-site mutations may partly account for phenotypic variability observed in many spastin-associated HSP patients.

In the current report, we evaluated the effect of two splice-site mutations affecting exon 12 of the SPAST gene in two different HSP families. We show that either a splice acceptor or a splice donor mutation causes exon 12 skipping, and both mutations generate a hypomorphic allele.

\section{Familles and methods}

\section{HSP familles}

Patients' clinical history was obtained, and a physical examination as well as routine electrophysiological testing was performed. In summary, the affected patients from both families presented a pure form of HSP with one patient (II2) from the 25913 HSP family found to have relatively severe phenotype (Fig. Ia and c). However, this patient had the longest disease duration of 17 years. Mean age at onset (AAO) in this family was 43.8 ( \pm 5.8$)$. The Spastic Paraplegia Rating Scale (SPRS) [16] was used to standardize and quantify results of the neurological examination. Informed consent was obtained from all patients. Detailed description of the patients' history and clinical evaluation is provided as Data $\$ 1$. Based on the local regulations, the study was exempt from institutional or ethics board approval.

\section{Mutation analysis}

The coding sequence of all 17 SPAST exons together with the flanking intronic sequence was amplified by
PCR from the genomic DNA of the index patients and sequenced in both directions. PCR and sequencing were carried out as previously described [7]. The p.G563A missense variant present in the exon 12 of the HSP 60 gene was sequenced as described previously [17].

\section{RT.PCR analysis}

Total RNA was isolated from the freshly drawn peripheral blood lymphocytes of patients by using the QIAamp RNA Blood Mini Kit (Qiagen, Hilden, Germany) according to the manufacturer's instructions. The RT-PCR analysis was performed as previously described [13]. The primer pair; SPG4_Ex10-11F and SPG4_Ex16-17R (Table S1, Data S1) were used to amplify the SPAST cDNA amplicon spanning from exon 10 to exon 17 . The amplified products were analyzed by agarose gel electrophoresis.

\section{Cloning and sequencing of RT-PCR product}

The SPAST RT-PCR products, which were amplified from total RNA of the patients, were cloned into pGEM-T Easy vector (Promega, Mannheim, Gemany) and sequenced using standard procedures.

\section{Quantitative allele-specific expression analysis}

For quantitative (q)-RT-PCR investigation, total RNA was extracted from lymphocytes with and without puromycin incubation. For puromycin treatment, freshly drawn blood samples from the patients were incubated for $6 \mathrm{~h}$ at $37^{\circ} \mathrm{C}$ on a rotating wheel in the presence or absence of puromycin $(200 \mu \mathrm{g} / \mathrm{ml})$. We also isolated total RNA from six unaffected individuals (similar age group) to use as controls in our analysis.

An amount of $2 \mu \mathrm{g}$ total RNA was used to synthesize CDNA with SuperScript II (Invitrogen) and random hexamer primers in a total volume of $20 \mu$. After synthesis, an additional volume of $10 \mu$ sterile $\mathrm{H}_{2} \mathrm{O}$ was added to the reaction mixture. Because of the relative activity of the encyme (as indicated by the manufacturer), the calculated concentration of synthesized CDNA was $\sim 30 \mathrm{ng} / \mu \mathrm{l}$. A total amount of $60 \mathrm{ng} \mathrm{cDNA}$ was used as template input for qRT-PCR.

The expression of each allele was quantified on a 7900 HT Sequence Detection System (Applied Bio systems, Darmstadt, Germany) by qRT-PCR. The primer combination hSSPAF.1/hsSPAR.1 amplifies a 129-bp fragment, and the FAM-labeled MGB-probe (minor groove binder) hsSPAPwt.l was used for detection of the wild-type allele. The primer combination 
(a)

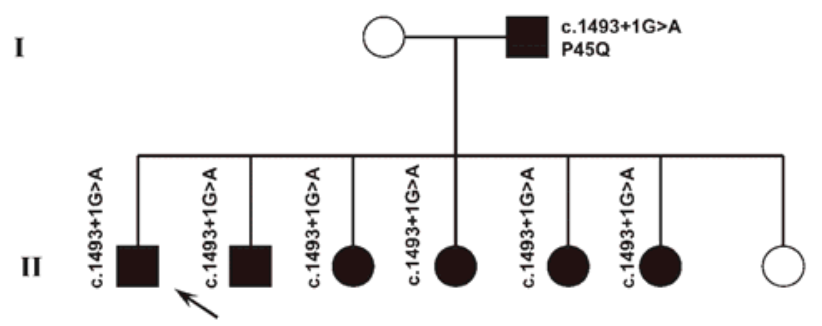

(b)

I

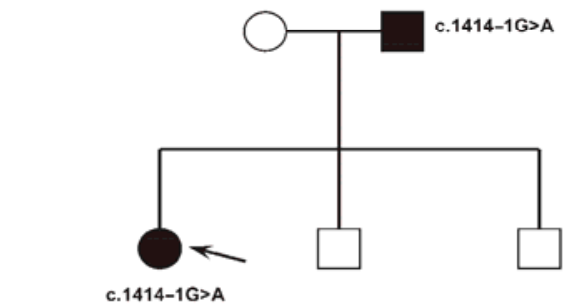

(c)

\begin{tabular}{|c|c|c|c|c|c|c|c|}
\hline Patient & $\begin{array}{l}\mathrm{AAO}^{1} \\
\text { (years) }\end{array}$ & $\begin{array}{l}\text { Duration } \\
\text { (years) }\end{array}$ & SPRS' $^{2}$ score & Bladder disturbance & MEP $^{3}$ & SSEP $^{4}$ & Neurography \\
\hline 11 & $30 ?$ & 57 & n.a.s & Incontinence & $\mathrm{CMCT}^{6} \uparrow$ & Path ${ }^{\top}$ & PNPs \\
\hline III & 50 & 4 & 3 & No & $\mathrm{CMCT} \uparrow$ & Path. & PNP \\
\hline 112 & 38 & 17 & 27 & Sphincter spasticity & $\mathrm{CMCT} \uparrow$ & Path. & PNP \\
\hline 113 & 49 & 2 & 0 & No & Normal & Path. & Normal \\
\hline 114 & 44 & 1 & 3 & No & $\mathrm{CMCT} \uparrow$ & Path. & PNP \\
\hline II 5 & 38 & 4 & 6 & No & Normal & Path. & PNP \\
\hline 116 & n.a. & n.a. & 0 & No & Normal & Normal & Normal \\
\hline
\end{tabular}

[1] AAO, Age at onset; [2] SPRS, Spastic Paraplegia Rating Scale; [3] MEP, Motor Evoked Potentials: [4] SSEP Somatosensory Evoked Potentials; [5] n.a., not available; [6] CMCT, Central motor conduction time; [7] Path, Pathological; [8] PNP. Polyneuropathy.

Figure 1 Pedigree of German HSP families with splice-site mutations. (a) In HSP family 25 913, in addition to index patient (III), five other siblings manifested the symptoms of HSP in varying degree and all the affected kindred inherited the $c .1493+1 \mathrm{G}>\mathrm{A}$ splice-site mutation from their father (I1), who was also heterozygous for the pP45Q variant. (b) In the HSP family 29408 , the index patient (II1) inherited the $c .1414-1 \mathrm{G}>\mathrm{A}$ splice-site mutation from her father (I1); she has two asymptomatic brothers, who were not tested for the identified mutation. (c) Clinical and neurological evaluation of the 25913 HSP family.

hsSPAF.3/hsSPAR.2 amplifies a 128-bp fragment, and the FAM-labeled MGB-probe hsSPAPmt.2 detected the mutated allele, in which exon 12 is skipped. A PPIA (NM_021130.3) gene-specific quantitative assay (primer combination hsCYCAF.1/hsCYCAR.1, FAM-labeled MGB-probe hsCYCAp.1R) was used for data normalization. The relative expression of the wild-type mutated allele was calculated as the ratio of the signal measured for the wild-type/mutated allele to the total signal of the mutated plus the wild-type allele given in percent. The qRT-PCR experiments were repeated four times with three technical replicate. The primer and probe sequences and their modifications are given in Table S1.

\section{Results}

Identification of putative splice-site mutations in the SPAST gene

We performed a mutational screen in the SPAST gene in the genomic DNA of the index patients from two German HSP families (25 913 and 29 408; Fig. 1) and identified two novel putative splice-site mutations namely $c .1493+1 \mathrm{G}>\mathrm{A}$ and $c .1414-1 \mathrm{G}>\mathrm{A}$, which were absent in 100 control chromosomes.

In the index patient (III) from the 25913 family (Fig. la), we identified a potential splice-site mutation $(c .1493+1 \mathrm{G}>\mathrm{A})$ in heterozygous state in the 
invariant splice donor junction sequence. Sequencing of the additional family members including the father (I1) and five affected siblings (II2-5) from the index patient revealed that all tested siblings inherited the c.1493 + 1G > A from their father (I1) (Fig. 1a). The seventh sibling (II7) of the index patient is not willing to undertake neurological and genetic testing and is apparently asymptomatic. The clinical evaluation of the 25913 family members indicated that one sibling (II2) of the index patient manifested a relatively severe phenotype compared to the other affected family members (Fig. 1c and Data S1). Previous studies have shown that missense variants such as p.S44L and p.P45Q act as an intragenic modifier, which in association with another disease-causing SPAST mutation increases the severity of HSP symptoms $[6,13,18,19]$. Sequencing of exon 1 of SPAST gene in the genomic DNA of the 25913 family members revealed that patient I1 (father) is heterozygous for the p.P45Q $(c .134 \mathrm{C}>\mathrm{A})$, but the rest of the family including II2 are wild type for either of the missense variants. To exclude the possibility of an intergenic modifier accounting for the severe phenotype in patient II2, we screened for the missense variant p.G563A in the HSP60 gene (OMIM: 118 190), which was recently reported as a modifier of SPAST-associated HSP phenotype [17]. However, sequencing of exon 12 of the HSP6O gene revealed that patient II 2 is negative for the p.G563A variant.

In the second HSP family (29 408), sequencing of the SPAST gene in the index patient (Fig. 1b, III) led to the identification of another putative splice-site mutation in intron $11(c .1414-1 \mathrm{G}>\mathrm{A})$ in heterozygous state in the invariant splice acceptor junction sequence. Sequencing of exon 12 of the SPAST gene in the genomic DNA of the father (Fig. 1b, Il) of the index patient confirmed that she inherited the mutated allele from her father.

\section{The splice-site mutations cause exon skipping}

The identified mutations $c .1493+1 \mathrm{G}>\mathrm{A}$ and c.1414-1G $>\mathrm{A}$ are located in the conserved splice donor and acceptor sites of exon 12 of SPAST. In silico analysis using a splice-site prediction program (http:/ www.fruitfly.org/seq_tools/splice.html) predicted that both mutations abolish the donor or acceptor sites of exon 12. RT-PCR amplification of the spastin transcript (spanning exon 10 till exon 17) from RNA of the index patients from both HSP families revealed a shorter and much weaker RT-PCR product of $\sim 341 \mathrm{bp}$ in size in addition to the full-length product of $\sim 421 \mathrm{bp}$ in size (Fig. 2a). Sequencing of these RT-PCR products confirmed that the shorter transcript lacked exon 12 of spastin (Fig. 2b).

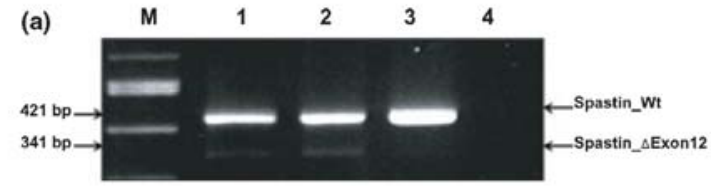

(b)

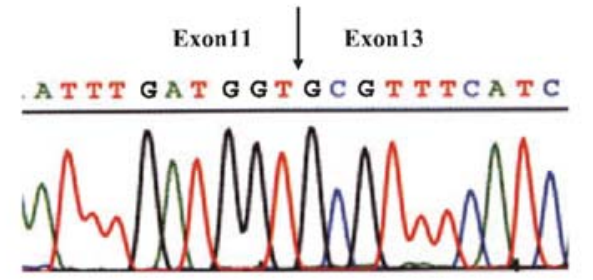

Figure 2 Exon 12 skipping of spastin caused by splice-site mutations. (a) The RT-PCR amplification of exon 10 till exon 17 of the spastin RNA of the index patients from both HSP families revealed two bands with sizes of 341 and 421 bp. These bands were visible in the index patient from family 25913 (lane 1) carrying the c. $1493+1 \mathrm{G}>\mathrm{A}$ splice-site mutation and in the index patient from family 29408 (lane 2) carrying the $c .1414-1 \mathrm{G}>\mathrm{A}$ splice-site mutation. In contrast, in the RNA sample of a control individual only the wild-type spastin product of size 421 bp was visible (lane 3), and no band was detectable in the negative control (lane 4, $\mathrm{H}_{2} \mathrm{O}$ ). M, molecular weight marker. (b) Sequencing of the RT-PCR product with the size of 341 bp revealed skipping of exon 12 of spastin caused by the splice-site mutations.

\section{Quantitative determination of SPAST transcript variants}

The diminished intensity of the transcript variant lacking exon 12 (referred now onwards as minor transcript) compared to the wild-type transcript (referred as major transcript) was visualized by gel electrophoresis (Fig. 2a). This could be either attributed to splicing from the mutant allele or attributed to the degradation of the aberrant transcript by nonsense-mediated decay (NMD) mechanism [20] as skipping of exon 12 will lead to a premature stop codon in the mRNA (p.Val472 AlafsX484). To investigate these possibilities, we performed a qRT-PCR analysis using allele-specific primers and probes (Fig. 3a and Table S1) [21] with total RNA isolated from lymphocytes treated with the antibiotic puromycin to inhibit NMD [22]. The relative quantification of expression of the major transcript revealed a reduced level of expression (mean range $78.8 \% \pm 3.9 \%$ ) in all patients when compared to the control group (Fig. 3b). The relative expression of major transcript when compared to the total amount of spastin variants (major + minor) by qRT-PCR revealed a much higher expression than the expected ratio of $50 \%$ in all assessed patients from both families (Fig. 3c). Accordingly, the relative expression of the minor transcript was lower $(21.1 \% \pm 3.6 \%$, Fig. 3c) In the RNA samples without puromycin treatment, the 
(a)

\begin{tabular}{|c|c|c|c|c|}
\hline \multirow[t]{2}{*}{ Major transcript } & 11 & 12 & 13 & 14 \\
\hline & \multicolumn{3}{|c|}{$\overline{\text { MGB probe } 1}$} & \\
\hline Minor transcript & 11 & 13 & & \\
\hline
\end{tabular}

(b)

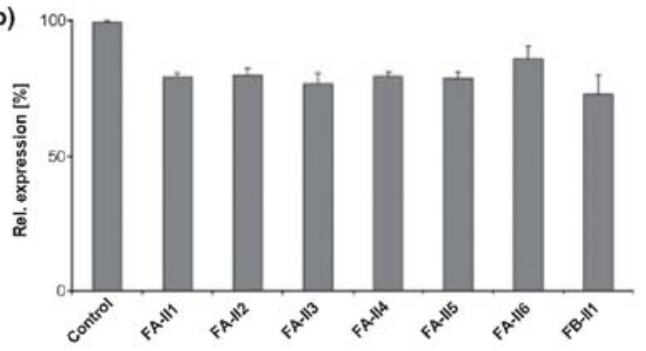

(c)

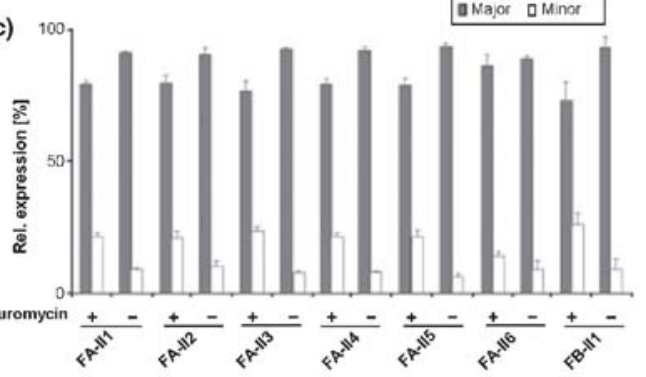

Figure 3 Quantitative allele-specific expression analysis. (a) Schematic diagram delineating the strategy to quantify the expression of wild-type spastin (major transcript) and exon 12-skipped spastin (minor transcript) by means of quantitative RT-PCR analysis using spastin-specific minor groove binder (MGB) Taqman probes. (b) Quantification of the expression of spastin major transcript in the total RNA isolated from lymphocytes (puromycin treated) of the siblings from the 25913 (family A, FA) HSP family and the index patient from the 29408 (family B. FB) HSP family when compared to mean level of spastin expression in the six unaffected control individuals. (c) Quantification of the relative expression of spastin major and minor transcripts in the 25913 family and the index patient from the 29408 family in total RNA isolated from puromycin (+) treated and untreated (-) lymphocytes. When nonsense-mediated decay (NMD) was inhibited by puromycin treatment, we observed that the major transcript was expressed at a level of $78.8 \% \pm 3.9 \%$ and the minor transcript at a level of $21.1 \% \pm 3.6 \%$ in all patients, suggesting a leaky splicing caused by both splice-site mutations. In RNA samples without puromycin treatment, we observed a lower level of minor transcript expression of $8.3 \% \pm 1.3 \%$, indicating that some amount of mutated mRNA was degraded by NMD. Major, wild-type transcript; Minor, mutant transcript.

relative expression of minor transcript was even lower $(8.3 \% \pm 1.3 \%)$ in all patients (Fig. 3c).

\section{Discussion}

In this study, we have characterized the consequence of two novel splice-site mutations $(c .1493+1 \mathrm{G}>\mathrm{A}$ and $c .1414-1 \mathrm{G}>\mathrm{A}$ ) in the SPAST gene in two different HSP families. Clinically, the patients from both families show pure HSP. The two identified splice-site mutations are located in the invariant splice acceptor and donor sites (AG_GT) of exon 12 of the SPAST gene and cause skipping of exon 12, which was confirmed by RT-PCR analysis. The intensity of the band corresponding to the mutant spastin variant was much weaker compared to the normal spastin product. As this difference could be either attributed to leaky splicing or degradation by NMD [20], we established a quantitative allele-specific expression assay by the means of qRT-PCR using spastin-specific TaqMan probes [21]. Quantification of the normal (major) transcript, after inhibition of NMD by puromycin treatment, revealed a much higher $(78.8 \% \pm 3.9 \%)$ expression than the expected $50 \%$ ratio in all patients when compared to the control samples. The expression of minor transcript was much lower $(8.3 \% \pm 1.3 \%)$ in samples without puromycin treatment, suggesting that a significant proportion of the minor mRNA was degraded through NMD. Our finding suggests that both splice-site mutations cause leaky splicing. We speculate that the manifestation of late AAO of HSP could be attributed to the hypomorphic nature of these splice-site mutations. Owing to a small sample size, this finding should be interpreted with discretion.

In the HSP family (25 913), all siblings had low SPRS score (0-6 points) with exception of one patient (II2; SPRS score of 27). The low SPRS scores in the mildly affected siblings are probably attributed to shorter duration of the disease. Interestingly, four of six affected siblings had polyneuropathy (Fig. 1c). Previously, lower motor neuron affection in SPASTassociated HSP patients was also reported in a British cohort [6].

Our initial working hypothesis was that a differential level of expression of the spastin variants (major and minor transcripts) could be a possible explanation for the clinical variability. However, there was no significant difference in the expression level of the spastin variants amongst the siblings, suggesting that other factors might be responsible for the intrafamilial variability. Previous studies reported that the presence of the intragenic variants p.S44L and p.P45Q in the $\mathrm{N}$-terminal region of spastin in trans with a diseasecausing SPAST mutation can act as disease aggravating phenotypic modifiers $[13,19]$. We identified the p.P45Q variant only in the genomic DNA of father (I1) of the 25913 family. However, all children of the patient (I1) were negative for p.P45Q as well as for the pS44L variant. Initially, it was reported that the p.P45Q variant in association with another SPAST mutation causes 
an early AAO [19]. However, late AAO (39 years) was also observed in a patient with HSP with fast progression of disease [6]. The observation of AAO in early third decade in the patient (II) with mild disease progression rate suggests that $p . P 450$ manifests variable effects depending upon ethnicity of the patient. Previously, a missense variant p.G563A in the HSP60 gene has been identified as an intergenic modifier causing an earlier onset of symptom in spastin-associated HSP [17]. However, the patient (II2) with relatively severe HSP was negative for the variant p.G563A in the HSP60 gene. In summary, neither an intra- nor intergenic modifier was identified, which could have served as a plausible explanation for the intrafamilial variability.

The quantitative assessment of the splice-site mutations was performed with RNA derived from lymphocytes. For that reason, it can be argued that this effect on splicing might not be representative for the brain or central nervous system, which is the relevant tissue in the context of HSP. However, in a previous study, several spastin splice-site mutations were characterized for leaky expression using RNA derived from lymphocytes [14]. This study also indicated that the splicing pattern of spastin is similar in both lymphocytes and brain, which are processed by the common splicing machinery [14].

In SPAST-associated HSP, splice-site mutations account for $17.4 \%(53 / 304)$ of all types of mutations (HGMD database). However, only few studies with limited molecular approaches were conducted to investigate and decipher the role of splice-site mutations in HSP. In this context, we demonstrate that the GRTPCR analysis using spastin-specific probes offers an easy to use, yet valuable assay system to investigate the role of most types of spastin splice-site mutations in HSP.

\section{Acknowledgements}

The authors thank the HSP patients/families for their participation in this study and B. Brandt as well as C. Wetzig for excellent technical assistance. This work was funded partly by the Deutsche Forschungsgemeinschaft Grant and institute internal fund to A. U. M

\section{References}

1. Harding AE Classification of the hereditary ataxias and paraplegias. Lancet 1983; 1: 1151-1155.

2. Harding AE. Hereditary spastic paraplegias. Semin Neurol $1993 ; 13: 333-336$.

3. Fink $J K$. The hereditary spastic paraplegias: nine genes and counting. Arch Neurol 2003; 60: 1045-1049.
4. Fonknechten N, Mavel D, Byrne P, et al. Spectrum of SPG4 mutations in autosomal dominant spastic paraplegia Hum Mol Genet 2000: 9: 637-644.

5. Hazan J, Fonknechten N, Mavel D, et al. Spastin, a new AAA protein, is altered in the most frequent form of autosomal dominant spastic paraplegia. Nat Genet 1999; 23: 296303 .

6. McDermott CJ, Burness CE, Kirby J, et al. Clinical features of hereditary spastic paraplegia due to spastin mutation. Neurology 2006; 67:45-51.

7. Sauter $S$, Miterski $B$, Klimpe $S$, et al Mutation analysis of the spastin gene (SPG4) in patients in Germany with autosomal dominant hereditary spastic paraplegia. Hum Mutat $2002 ; 20: 127-132$.

8. Shoukier M. Neesen I. Sauter SM, et al. Expansion of mutation spectrum, determination of mutation cluster regions and predictive structural classification of SPAST mutations in hereditary spastic paraplegia. Eu J Hum Genet $2009 ; 17: 187-194$.

9. Hanson PI, Whiteheart SW. AAA + proteins: have engine, will work. Nat Rev Mol Cell Biol 2005; 6: 519-529.

10. Patel S, Latterich M. The AAA team: related ATPases with diverse functions. Trends Cell Biol 1998; 8: 6571 .

11. Beetz C, Nygren AO, Schickel J, et al. High frequency of partial SPAST deletions in autosomal dominant hereditary spastic paraplegia. Newrology 2006; 67: 1926-1930.

12. Depienne C. Fedirko E, Forlani S, et al. Exon deletions of SPG4 are a frequent cause of hereditary spastic paraplegia. J Med Genet 2007; 44: 281-284.

13. Pantakani DV, Zechner U, Arygriou L et al. Compound heterozygosity in the SPG4 gene causes hereditary spastic paraplegia. Cin Genet 2008; 73:268 272

14. Svenson IK, Ashley-Koch AE, Gaskell PC, et al. Identification and expression analysis of spastin gene mutations in hereditary spastic paraplegia. Am I Hum Genet 2001; 68: $1077-1085$.

15. Svenson IK, Ashley-Koch AE, Pericak-Vance MA. Marchuk DA. A second leaky splice-site mutation in the spastin gene. Am I Hum Genet 2001; 69: 14071409.

16. Schule $\mathbb{R}$, Holland-Letz $T$, Klimpe $S$, et al. The Spastic Paraplegia Rating Scale (SPRS): a reliable and valid measure of disease severity. Neurology $2006 ; 67: 430-434$.

17. Hewamadduma CA, Kirby J, Kershaw $\mathrm{C}$, et al. $\mathrm{HSP} P 00$ is a rare cause of hereditary spastic paraparesis, but may act as a genetic modifier. Newrology 2008; 70: 1717-1718.

18. Chinnery PF, Keers SM, Holden MJ, Ramesh V, Dalton A. Infantile hereditary spastic paraparesis due to codominant mutations in the spastin gene. Neurology 2004; 63: 710-712.

19. Svenson IK, Kloos MT. Gaskell PC, et al. Intragenic modifers of hereditary spastic paraplegia due to spastin gene mutations. Neurogenetics 2004; 5: $157-164$.

20. Chang YF, Imam IS, Wilkinson MF. The nonsensemediated decay RNA surveillance pathway. Anmu Rev Biochen 2007: 76: 51-74.

21. Afonina I, Zivarts M, Kutyavin I, et al. Efficient priming of PCR with short oligonucleotides conjugated to a minor groove binder. Nucleic Acids Res 1997; 25: 2657-2660.

22. Andreutt-Zaugg C, Scott RJ, Iggo R. Inhibition of nonsense-mediated messenger RNA decay in clinical samples facilitates detection of human MSH2 mutations with an in vivo fusion protein assay and conventional techniques. Cancer Res 1997; 57: 3288-3293. 


\section{Supporting information}

Additional Supporting Information may be found in the online version of this article:

Table S1. Oligonucleotides sequence and their modifications for qRT-PCR analysis.
Data S1. Clinical information.

Please note: Wiley-Blackwell is not responsible for the content or functionality of any supporting materials supplied by the authors. Any queries (other than missing material) should be directed to the corresponding author for the article. 


\section{Online supplementary information}

Table S1: Oligonucleotides sequence and their modifications for qRT-PCR analysis.

\begin{tabular}{|c|c|c|}
\hline Primer Name & Sequence (5’-3’ orientation) & Application \\
\hline 18S-fwd & CGC AAA TTA CCC ACT CCC G & \multirow{2}{*}{$\begin{array}{l}\text { Quantification of } 18 S \text { rRNA } \\
\text { gene expression }\end{array}$} \\
\hline 18S-rev2 & TTC CAA TTA CAG GGC CTC GAA & \\
\hline hsSPAF.1 & GAA TTT GAT GGT GTA CAG TCT GCT GG & \multirow{3}{*}{$\begin{array}{l}\text { Quantification of spastin } \\
\text { major allele expression }\end{array}$} \\
\hline hsSPAR.1 & ATT TGG TAA AGA CAC ATA TAC CCG TTT G & \\
\hline hsSPAPwt.1 & $\mathrm{FAM}^{[1]} \sim$ TGA AAC GCC TGA GAA CA $\sim \mathrm{MGB}^{[2]}$ & \\
\hline hsSPAF.3 & CTA ATA GAA TTT GAT GGT GCG TTT CA & \multirow{3}{*}{$\begin{array}{l}\text { Quantification of spastin } \\
\text { minor allele expression }\end{array}$} \\
\hline hsSPAR.2 & GCT AGT TCT TTT TGG GTC AAT GGA CTT & \\
\hline hsSPAPmt.2 & FAM $^{[1]} \sim$ CAA ACG GGT ATA TGT GTC TT $\sim$ MGB $^{[2]}$ & \\
\hline SPG4_Ex10-11F & TTTATAGATGAAGTTGATAGCCTTTTG & \multirow{2}{*}{$\begin{array}{l}\text { RT-PCR amplification of } \\
\text { spastin }\end{array}$} \\
\hline SPG4_Ex16-17R & TTCTCATCTCACTGGCAGACAT & \\
\hline
\end{tabular}

[1] FAM: 6-Carboxyfluorescein; [2] MGB: Minor Groove Binder

\section{Clinical information}

\section{The family 25913}

With one exception, all 5 examined siblings of the second generation presented a mild clinical phenotype with SPRS scores ranging from 0-6 points. In contrast, the more affected brother scored 27 points on the SPRS. In 4 of the 6 siblings polyneuropathy (PNP) was diagnosed. One sibling was not willing to undertake neurological and genetic testing and is apparently asymptomatic.

\section{Patient I1, 87years}

This patient first arrived at our clinic 12 years ago. He then described a slowly progressive gait disorder with stiffness in his legs which began when he was about 20 years old. Up to his late seventies, he was able to walk more than 500 m without any support; however, since then 
he needs two walking aids. Additional symptoms include bladder disturbance and an impaired vibration sense without loss of sensation of touch or pinprick. A PNP had also been diagnosed some years before and Diabetes Mellitus had been excluded. The latest clinical examination was performed at 80 years old. On examination, he had exaggerated tendon reflexes in the upper and lower limbs, Babinski’s sign and a sever leg spasticity. He had no sense of vibration in his legs. He then was able to walk a few meters with a rollator but was mainly sitting in a wheelchair. In addition, he suffered from a hemiparesis after a right hemispherical stroke, was depressed and presented signs of dementia. According to his children, actually he is unable to walk, wheelchair bound and suffers from urinary incontinence and severe dementia. No actual electrophysiological testing was available.

His father died at age 49 with some gait disturbance but no further information is available. His mother died at age 94 with no significant gait disorder.

\section{Patient II1, 56years}

Around 5 years ago he first noticed a slowing of gait and a mild stiffness of his legs but had no further symptoms. On examination, brisk lower limb tendon reflexes, Babinski’s sign, mild spastic gait and mild spastic increase of adductor muscle tonus were observed, but no sensory impairment was detected. He scored 3 points on the SPRS. Additionally he has been treated for Diabetes Mellitus. Electrophysiological examination revealed pathological MEPs to lower limbs, pathological SSEPs to upper and lower limbs and a sensorimotor PNP of the lower limbs were found (Fig. 1C). He is fully active and athletic, enjoying mountain climbing and skiing.He has one asymptomatic child.

\section{Patient II2, 55years}

In his late thirties he first realized a gait disturbance and 12 years ago he was first diagnosed as having HSP together with his father. When last examined at the clinic, disease duration was 17 years and he was able to walk 50 meters with two canes, however, climbing stairs was very difficult for him. He also suffers from a bladder disturbance with spastic sphincter tonus. His 
gait was clearly spastic, muscle tone increased mainly in adductor muscles (Ashworth 3). His score on the SPRS was 27 (Fig. 1C), 1 year before it was 13. The electrophysiological examination revealed pathological MEPs, SSEPs and a sensorimotor PNP to the lower limbs (Fig. 1C). He has two asymptomatic children.

\section{Patient II3, 51years}

Two years ago she noticed unstableness and occasional stumbling while jogging, but no additional symptoms. On examination, brisk lower limb tendon reflexes and Babinski’s sign were observed, however in SPRS evaluation she scored zero points. Tibial nerve SSEPs could not be elicited, which was the sole pathological finding (Fig. 1C). She has two asymptomatic children.

\section{Patient II4, 45years}

Also athletic, she has been complaining for over a year about gait disturbance and stumbling without additional symptoms. On examination she manifested brisk lower limb tendon reflexes and Babinski's sign, adductor spasticity and a spastic gait resulting in 3 points on the SPRS evaluation. The electrophysiological testing revealed pathological MEPs, SSEPs and a sensorimotor PNP to the lower limbs (Fig. 1C). She has no children.

\section{Patient II5, 42years}

Four years go she noticed a slowly progressive gait disorder but no other signs. On examination she revealed brisk lower limb tendon reflexes and Babinski’s sign, adductor spasticity and a spastic gait resulting in 6 points on the SPRS score. MEPs were normal in contrast to pathological SSEPs to upper and lower limbs and sensorimotor PNP to the lower limbs (Fig. 1C). She has no children.

\section{Patient II6, 37years}

This patient describes no actual symptoms although she used to suffer from some gait disturbance which had vanished when she became physically active. On examination, brisk upper and lower limb tendon reflexes without Babinski’s sign were found, which in terms of 
SPRS score was equivalent to zero points (Fig. 1C). The MEPs, SSEPs and neurography were normal (Fig. 1C). She has three asymptomatic children.

\section{The 29408 family}

Patient I1, 75years

Since his fifties, he noticed a progressive gait disturbance. Currently, he needs permanent walking support and suffers from lumbar pain. On examination, hyperreflexia of upper and lower limbs with severe spasticity of lower limbs with Babinski's sign was observed. The Neurography, MEP and SSEP were in the normal range. He was diagnosed with HSP in 1989 and information was drawn from his clinical reports from 1989 and 2004.

Patient II2, 43 years

The 43 year old index patient has complained for 5 years, about a slowly progressive gait disturbance accompanied by urinary urge. She is still able to run and if she walks slowly then walking distance is not affected. On examination, exaggerated tendon reflexes of upper and lower limbs were found with Babinski’s sign, adductor spasticity and discrete spastic gait. Vibration sense was impaired without any further affection of the sensory system. She scored 8 points on the SPRS. The MRI of the head and the spine was normal. Electrophysiological examination revealed no pathologies. She has an asymptomatic 18 year old daughter and two asymptomatic brothers aged 32 and 39 years.

The family history reveals affected family members in three generations. The mother of the patient I1 had suffered from spastic gait for more than 25 years before she died at age 67. 


\subsection{Publikation III}

Functional evaluation of paraplegin mutations by a yeast complementation assay.

DOI: 10.1002/humu.21226

Der Status der Publikation:

Die Arbeit ist in der Zeitschrift Human Mutation (5-Year Journal Impact Factor 6.711(2009)), Band 31(2010), Seiten 617-621, erschienen

\section{Die Namen der Koautoren:}

Florian Bonn, Krishna D.V. Pantakani, Moneef Shoukier, Thomas Langer und Ashraf U. Mannan.

\section{Der Anteil der Koautoren an dem Gesamtprojekt:}

Florian Bonn: Die Durchführung des Hefe-Komplementations-Assays

Krishna D.V. Pantakani: Die In-Silico-Evolution der Missense-Mutationen im SPG7-Gen

Moneef Shoukier: Die Mutationsanalysen im SPG7-Gen

Thomas Langer: Design des Hefe-Komplementations-Assays sowie das Schreiben des Manuskripts

Ashraf U. Mannan : Die Beteiligung an den Mutationsanalysen im SPG7-Gen und Durchsicht des Manuskripts 


\title{
Functional Evaluation of Paraplegin Mutations by a Yeast Complementation Assay
}

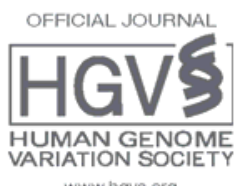

\author{
Florian Bonn, ${ }^{1}$ Krishna Pantakani, ${ }^{2}$ Moneef Shoukier, ${ }^{2}$ Thomas Langer, ${ }^{1,3}$ and Ashraf U. Mannan ${ }^{2,4 *}$ \\ 'Institute of Genetics, Center for Molecular Medicine (CMMC), Cologne Excellence Cluster on Cellular Stress Responses in Aging-Associated \\ Diseases (CECAD), University of Cologne, Cologne, Germany; ${ }^{2}$ Institute of Human Genetics, University of Goettingen, Goettingen, Germany; \\ ${ }^{3}$ Max-Planck-Institute for Biology of Aging, Cologne, Germany, ${ }^{4}$ DFG-Research Center Molecular Physiology of the Brain, Goettingen, Germany \\ Communicated by Peter J. Oefner \\ Received 17 November 2009; accepted revised manuscript 3 February 2010 \\ Published online 25 February 2010 in Wiley InterScience (www.interscience.wiley.com). DOI 10.1002/humu.21226
}

ABSTRACT: An autosomal recessive form of hereditary spastic paraplegia (AR-HSP) is primarily caused by mutations in the SPG7 gene, which codes for paraplegin, a subunit of the hetero-oligomeric m-AAA protease in mitochondria. In the current study, sequencing of the SPG7 gene in the genomic DNA of 25 unrelated HSP individuals/families led to the identification of two HSP patients with compound heterozygous mutations (p.G349S/p.W583C and p.A510V/p.N739KfsX741) in the coding sequence of the SPG7 gene. We used a yeast complementation assay to evaluate the functional consequence of novel SPG7 sequence variants detected in the HSP patients. We assessed the proteolytic activity of hetero-oligomeric m-AAA proteases composed of paraplegin variant(s) and proteolytically inactive forms of AFG3L2 (AFG3L2 $2^{\mathrm{E} 575 \mathrm{Q}}$ or AFG3L2 ${ }^{\mathrm{K} 354 \mathrm{~A}}$ ) upon expression in m-AAA protease-deficient yeast cells. We demonstrate that the newly identified paraplegin variants perturb the proteolytic function of hetero-oligomeric m-AAA protease. Moreover, commonly occurring silent polymorphisms such as p.T503A and p.R688Q could be distinguished from mutations (p.G349S, p.W583C, p.A510V, and p.N739KfsX741) in our HSP cohort. The yeast complementation assay thus can serve as a reliable system to distinguish a pathogenic mutation from a silent polymorphism for any novel SPG7 sequence variant, which will facilitate the interpretation of genetic data for SPG7.

Hum Mutat 31:617-621, 2010. (c) 2010 Wiley-Liss, Inc.

KEY WORDS: SPG7; paraplegin; yeast complementation assay; m-AAA protease

\section{Introduction}

Hereditary spastic paraplegias (HSP) are a group of heterogeneous neurodegenerative disorders, which are clinically characterized by progressive spastic paralysis in the lower limbs [Depienne et al., 2007; Harding, 1983]. Mutations in the SPG7

Additional Supporting Information may be found in the online version of this article. *Correspondence to: Ashraf U. Mannan, Institute of Human Genetics, University of Goettingen, Heinrich-Dueker-Weg 12, D-37073, Goettingen, Germany.

E-mail: amannan@gwdg.de gene (MIM 602783) cause an autosomal recessive (AR) form of HSP [Arnoldi et al., 2008; Brugman et al., 2008; Casari et al., 1998; Elleuch et al., 2006; McDermott et al., 2001; Tzoulis et al., 2008; Warnecke et al., 2007; Wilkinson et al., 2004]. The SPG7 gene codes for paraplegin, which contains an M41 metallopeptidase domain and an ATPase domain characteristic of the AAA family of ATPases [Langer, 2000]. It assembles with homologous AFG3L2 (MIM 604581) subunits into an oligomeric m-AAA protease complex, which localize to the inner membrane of mitochondria [Atorino et al., 2003; Koppen et al., 2007]. The m-AAA proteases exert dual activities and mediate both protein degradation and activation in mitochondria [Leonhard et al., 2000; Nolden et al., 2006; Rugarli and Langer, 2006; Tatsuta and Langer, 2009].

In yeast, the m-AAA protease is composed of conserved Ytalo and Yta12 subunits and is essential for the maintenance of respiration [Arlt et al., 1998]. Yeast cells lacking the $m$-AAA

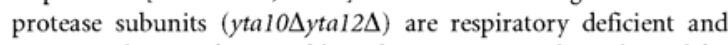
cannot utilize nonfermentable carbon sources, such as glycerol for growth [Arlt et al., 1998; Atorino et al., 2003]. Processing of the ribosomal subunit MrpL32 by the $m$-AAA protease is a prerequisite for ribosome assembly and synthesis of essential respiratory chain subunits within mitochondria [Nolden et al., 2005]. Expression of the human m-AAA protease, composed by paraplegin and AFG3L2 subunits, can functionally complement for yeast m-AAA protease and restore respiratory growth of yta10 $\Delta$ yta12 $\Delta$ yeast cells [Atorino et al., 2003; Augustin et al., 2009; Koppen et al., 2007]. As proteolysis by the m-AAA protease is necessary for respiratory growth [Arlt et al., 1998], complementation upon expression of paraplegin and AFG3L2 indicates that they are proteolytically active in yeast. Accordingly, complementation in yeast can be used as a model system to evaluate the proteolytic activity of paraplegin and the pathogenic consequence of paraplegin variants identified in HSP patients.

Screening for mutations in the SPG7 gene by various groups has identified over 29 different mutations (HGMD database, professional release 2009.4; https://portal.biobase-international.com/ hgmd/pro/start.php). However, the coding sequence of the SPG7 gene also consists of several sequence variants of unknown consequences/status [Arnoldi et al., 2008; Brugman et al., 2008; Elleuch et al., 2006]. The presence of these uncharacterized sequence variants in the $S P G 7$ gene makes it very difficult to interpret the data from the genetic analysis. No experimental system has been applied to functionally evaluate these identified sequence variants of the $S P G 7$ gene and to distinguish silent polymorphisms from disease-causing mutations. Here, we have utilized the yeast-complementation assay to assess the pathogenic 
properties of the identified sequence variants in the $S P G 7$ gene in a HSP cohort.

\section{Materials and Methods}

\section{HSP Cases and Mutation Analysis}

A group of 25 unrelated HSP individuals/families, with indication of an AR or a sporadic HSP, were screened for mutation in the SPG7 gene. For the HSP_28142 family with SPG7 mutations (Fig. 1), the clinical information is provided in the online Supporting Information. Informed consent was obtained from all probands for genetic analysis.

For the mutational screen, the genomic DNA from lymphocytes of patients was isolated using standard procedures. All the 17 exons of the SPG7 gene were polymerase chain reaction (PCR) amplified and sequenced as described previously [Brugman et al., 2008; Wilkinson et al., 2004]. The variants c.1045G > A (p.G349S) and $c .1749 \mathrm{G}>\mathrm{C}$ (p.W583C) were screened by restriction digestion (BIpI and $S p h \mathrm{I})$ analysis in the control population.

According to the Human Genome Variation Society instructions (www.hgvs.org/mutnomen), nucleotide numbering refers to cDNA numbering with the A of the ATG codon numbered as +1 . NM_003119.2 was used as reference sequence. NP_003110.1 was used as protein reference sequence.

\section{Yeast Complementation Assay}

For the yeast complementation assay (Fig. 2), a combination of human wild-type or mutant AFG3L2 was expressed with either wild-type or mutant paraplegin in a previously generated yeast

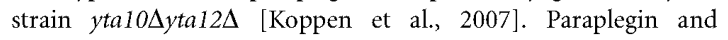
AFG3L2 were mutagenized in the yeast expression constructs using the QuickChange ${ }^{\circledR}$ XL Site-Directed Mutagenesis Kit (Stratagene, LaJolla, CA); primer sequence and cloning procedure are provided in the online Supporting Information. Yeast cells were grown according to standard procedures at $30^{\circ} \mathrm{C}$ in $\mathrm{YP}$ medium containing $2 \%(\mathrm{w} / \mathrm{v})$ glucose. For testing the respiratory activity, yeast cells were grown at $30^{\circ} \mathrm{C}$ on solid state or in the liquid YY media (Supp. Fig. S1) containing 3\% (w/v) glycerol as the sole carbon source. Processing of the $m$-AAA protease substrate MrpL32 was evaluated by Western blot as described previously [Koppen et al., 2007; Nolden et al., 2005].

\section{Results}

\section{SPG7 Mutations Analysis in the HSP Cohort}

Sequencing of the SPG7 gene in the genomic DNA of 25 unrelated HSP individuals/families (6 AR and 19 sporadic cases) led to the identification of compound heterozygous mutations in two probands, namely, 28135 and 28142. In the proband 28142 (Fig. 1, II-5), segregation analysis in the family members confirmed that the patients inherited the heterozygous mutations; c.1045G > A (p.G349S) and c.1749G >C (p.W583C) from his parents (Fig. 1). Also, one affected sister of the index patient (II-2, Fig. 1) was compound heterozygous for these mutations. Other siblings were either heterozygous for one mutation or wild type. In a control population (756 chromosomes), we detected c.1045G $>$ A variant in $5 / 756(0.7 \%)$ cases (in heterozygous state); however, the variant c. $1749 \mathrm{G}>\mathrm{C}$ was not detected (0/756). In another patient (28135) with sporadic HSP, we detected two previously reported SPG7 mutations, namely, c.1529C $>\mathrm{T}$ (p.A510V) [Brugman et al., 2008; Elleuch et al., 2006] and an insertion mutation (SPG7 $7^{\text {ins }}$ ) c.2215_2216insA (p.N739KfsX741) [Casari et al., 1998]. In the control population, we detected the variant p.A510V with an incidence rate of $1 \%$ ( $1 / 100$ chromosomes). Additionally, in several HSP cases we detected two nonsynonymous polymorphisms (p.T503A and p.R688Q) in the double heterozygous state (5/25).

\section{In Silico Analysis of Paraplegin Missense Sequence} Variants

Our observation of p.G349S and p.A510V sequence variants in the control population prompted us to perform in silico analysis by SIFT and PolyPhen software $[\mathrm{Ng}$ and Henikoff, 2003; Ramensky et al., 2002] (also, see the online Supporting Information) on the identified paraplegin missense sequence variants as well as nonsynonymous polymorphism (from Ensemble database). Both programs predict that p.G349, p.A510,

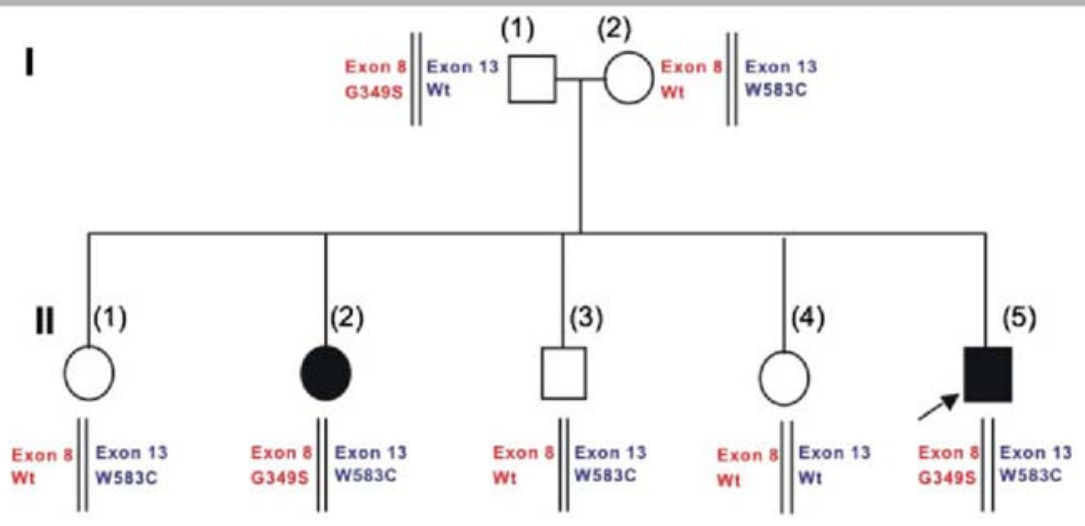

Figure 1. Pedigree of a German HSP family (28142) showing segregation of c.1045G $>$ A (p.G349S) and c.1749G $>C$ (p.W583C) sequence variants of the SPG7 gene in the family members. The segregation analysis confirmed an autosomal recessive mode of transmission with either parents (I-1 and I-2) harboring only one variant in heterozygous state. The index patient (II-5) and another sibling (II-2) are compound heterozygous for both variants and were affected with HSP. The other siblings are either heterozygous for one sequence variant (c.1749G $>$ C) or wild type, and all are asymptomatic for HSP. 
A WT

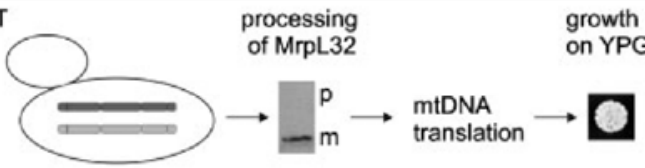

$B \Delta \Delta$

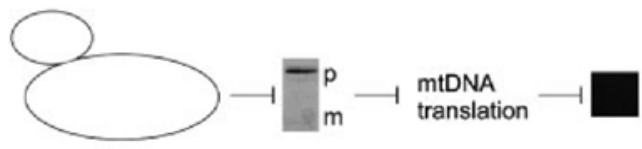

C $\triangle \triangle \mathrm{SPG} 7$ and $\mathrm{AFG} 3 \mathrm{~L} 2$

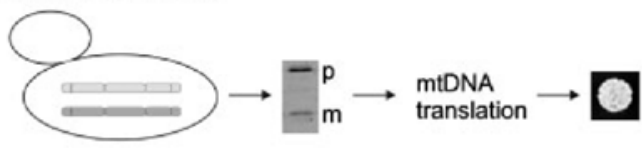

D $\triangle \triangle$ SPG7 and mutated AFG3L2

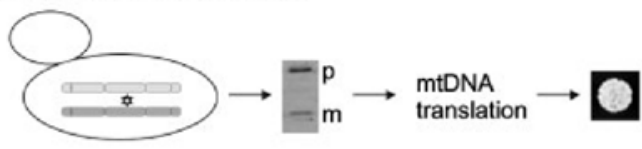

E $\triangle \triangle$ mutated SPG7 and mutated AFG3L2

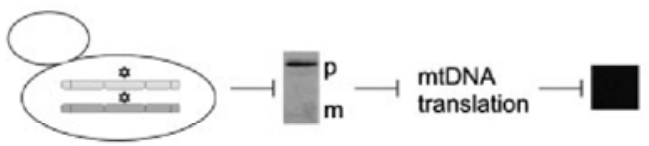

Figure 2. Schematic illustration of various stages of the yeast complementation assay. The proteolytic activity of m-AAA protease complexes (composed of Yta10 and Yta12 subunits in yeast) is assessed by monitoring the respiratory growth of the yeast on the nonfermentable carbon source glycerol. Proteolytic processing of the ribosomal subunit MrpL32 to the mature form by the m-AAA protease is a prerequisite for the assembly of mitochondrial ribosomes and synthesis of respiratory chain subunits within mitochondria (A).

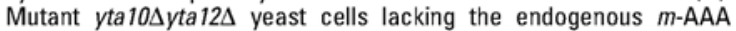
protease are respiratory deficient and accumulate the precursor form of MrpL32 (B). Expression of human paraplegin (SPG7) and AFG3L2 in

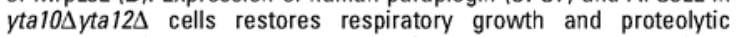
maturation of MrpL32, demonstrating functional conservation of the yeast and human m-AAA protease (C). Similarly, paraplegin (SPG7) restores (at least partially) MrpL32 processing and respiratory growth when coexpressed with inactive AFG3L2 subunits (D). In contrast, inactive mutant paraplegin variants do not promote MrpL32 processing and respiratory growth when coexpressed with inactive AFG3L2 subunits (E). p, precursor; m, mature; $\Delta \Delta$, yta10 $\Delta$ yta12 $\Delta$; WT, wild type; SPG7, paraplegin.

and p.W583 residues substitution could elicit deleterious effects on the protein function (Supp. Table S1).

\section{Activity of Paraplegin Variants Expressed in m-AAA Protease-Deficient Yeast Cells}

To examine their functional activity, paraplegin and variants

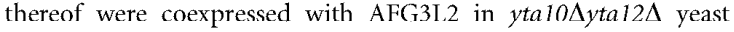
cells. Respiratory growth on the nonfermentable carbon source glycerol (Figs. 3A, 4A, and Supp. Fig. S2) and at least in part, processing of MrpL32 was restored regardless whether paraplegin or its mutant forms were expressed (Figs. 3A, 4A, and Supp. Fig. S2). This could reflect the activity of homo-oligomeric
AFG3L2 complexes or intermolecular complementation within hetero-oligomeric $m$-AAA protease complexes composed of paraplegin and AFG3L2 subunits, as previous studies have demonstrated that $m$-AAA protease activity is maintained, if only one subunit exerts proteolytic activity [Arlt et al., 1996, 1998].

We therefore coexpressed paraplegin and its variants thereof with proteolytically inactive AFG3L2. Notably, mutations in the proteolytic and AAA domain of the protease subunits may have different effects on m-AAA protease activity (Fig. 3C). Intersubunit complementation within m-AAA protease complexes occurs if the proteolytic site or the Walker A motif of one subunit is mutated. Mutations in the Walker A motif abolish ATP-binding, and therefore the ATPase activity of the affected subunit. However, assembled $m$-AAA proteases harboring mutant subunits exert ATPase activity if subunits with ATPase activity are present in the same complex [Arlt et al., 1998; Augustin et al., 2009]. We therefore coexpressed paraplegin mutants with either $\mathrm{AFG} 3 \mathrm{~L} 2^{\mathrm{E} 575 \mathrm{Q}}$ harboring a mutation in the proteolytic site or with $\mathrm{AFG} 3 \mathrm{~L} 2^{\mathrm{K} 354 \mathrm{~A}}$ carrying a mutation in the Walker A motif in yta10 $\Delta$ yta $12 \Delta$ cells (Figs. 3A, 4A, Supp. Figs. S1 and Fig. S2). Homo-oligomeric AFG3L2 complexes are inactive in these cells allowing monitoring specifically the activity of hetero-oligomeric $m$-AAA proteases composed of mutant AFG3L2 subunits and paraplegin or variants. Respiration was maintained if the silent paraplegin variants; p.T503A or p.R688Q (Supp. Table S1) were coexpressed with proteolytically inactive AFG3L2 ${ }^{\mathrm{E} 575 \mathrm{Q}}$ (Supp. Fig. S2). In contrast, presence of the variants p.G349S, p.W583C, p.A510V, and $S P G 7^{\text {ins }}$ did not allow respiratory growth or MrpL32 processing, if the function of AFG3L2 was impaired (Figs. 3 and 4). Interestingly, the paraplegin variants carrying the mutation p.G349S and p.A510V within the AAA domain, when coexpressed with proteolytically inactive $\mathrm{AFG} 3 \mathrm{~L} 2^{\mathrm{E} 575 \mathrm{Q}}$ restored weak growth on glycerol containing medium (Figs. 3A and 4A). This partial complementation can be explained by the presence of a functionally intact AAA domain within the AFG3L2 ${ }^{\mathrm{E} 575 \mathrm{Q}}$ subunit in the $m$-AAA complex. If these paraplegin variants (p.G349S and p.A510V) were coexpressed with AFG3L2 ${ }^{\mathrm{K} 354 \mathrm{~A}}$ harboring a mutant Walker A site, respiratory growth was inhibited completely (Figs. 3A and 4A).

These experiments demonstrate that the function of the paraplegin variants p.G349S, p.W583C, p.A510V, and SPG7 ${ }^{\text {ins }}$ are impaired. At the same time, the two identified silent polymorphisms (p.T503A and p.R688Q) in our HSP cohort were benign, as were predicted by in silico analyses (Supp. Table S1).

\section{Discussion}

Recent screens in sporadic and AR-HSP has led to a considerable increase in the number of identified SPG7 mutations, which now include 29 different mutations (HGMD database). However, the genetic data from the $S P G 7$ mutational screen is difficult to interpret, as several studies reported numerous sequence variants in the $S P G 7$ gene with unknown status/ consequence. A significant finding was from Elleuch and colleagues [2006], who reported 27 polymorphisms and 14 variants of unknown status compared to only 6 mutations in a HSP cohort. Furthermore, they described 20 HSP families with at least one variant at the heterozygous state, that was absent in two large control population. Similarly, other mutational screens have also identified HSP cases with a heterozygous variant in SPG7 [Arnoldi et al., 2008; Brugman et al., 2008].

The major challenge that arises from $S P G 7$ genetic analysis is how to distinguish deleterious variants from silent polymorphisms. 


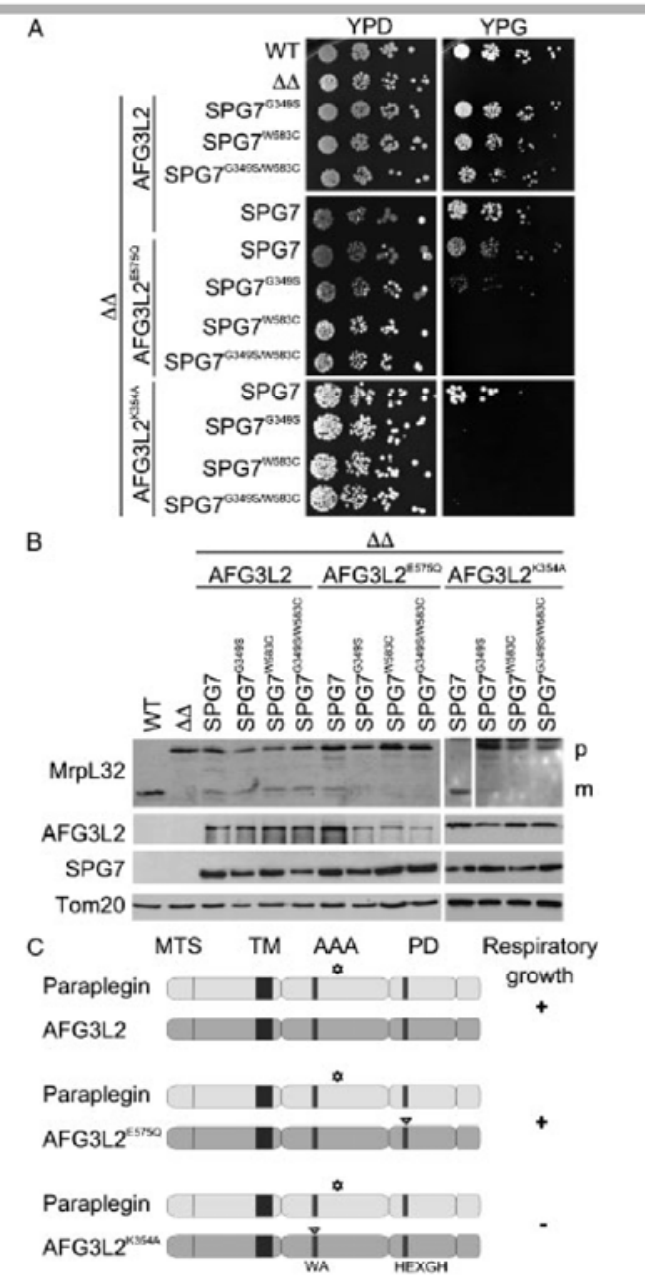

Figure 3. Proteolytic activity of hetero-oligomeric m-AAA protease complexes containing paraplegin variants identified in the HSP patient 28142. Respiratory growth of yta10 1 yta $12 \Delta$ cells expressing human $m$ AAA protease subunits. The paraplegin variants p.G349S or p.W583C identified in the HSP patient 28142 were coexpressed with AFG3L2,
AFG3L2 ${ }^{\mathrm{E} 5750}$, or AFG3L2 ${ }^{\mathrm{K} 354 \mathrm{~A}}$ in $\Delta y$ ta $10 \Delta$ yta12 cells. The yeast cell growth was analyzed at $30^{\circ} \mathrm{C}$ on glucose- (YPD) or glycerol-containing (YPG) media (A). Processing of yeast MrpL32 by human m-AAA

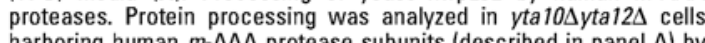
harboring human m-AAA protease subunits (described in panel A) by SDS-PAGE and immunoblotting. Maturation of MrpL32 substrate was monitored in isolated mitochondria by immunoblotting using polyclonal antisera directed against MrpL32. As a loading control the outer membrane protein Tom 20 was used. The expression of paraplegin and AFG3L2 in yeast was confirmed by immunoblotting. $p$, precursor

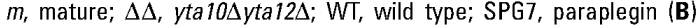
Assembly of paraplegin variants into functionally active $m$-AAA protease complexes. Schematic representation of the domain structure of paraplegin and AFG3L2 proteins, the asterisk denotes a mutation in the AAA domain of paraplegin, which inactivates the ATPase activity. The functional consequences of the mutation can be examined by coexpressing the paraplegin variant with wild-type AFG3L2. AFG3L2 ${ }^{\mathrm{K} 354 \mathrm{~A}}$ harboring a mutation in the Walker A motif, and $A F G 3 L 2^{E 5750}$ harboring mutation in the proteolytic sites (as indicated by triangles). Functional activity is assessed by monitoring respiratory growth of the cells (C).

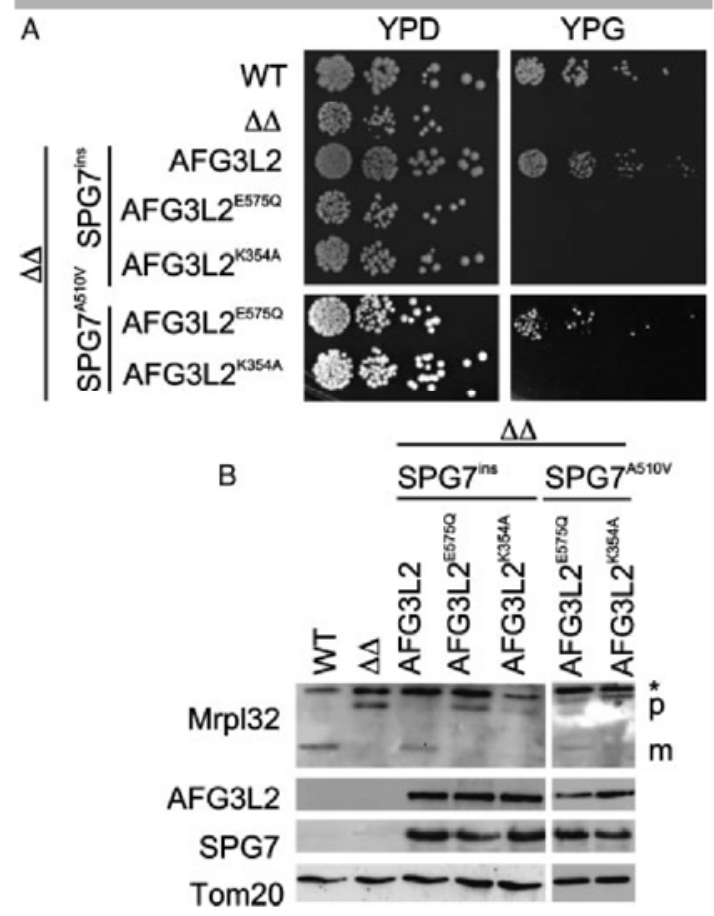

Figure 4. Proteolytic activity of hetero-oligomeric m-AAA protease complexes containing paraplegin variants identified in the HSP patient

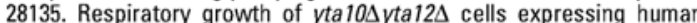
m-AAA protease subunits. The paraplegin variants $P$ A510V or Ins identified in the HSP patient 28142, were coexpressed with AFG3L2

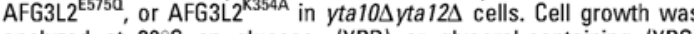
analyzed at $30^{\circ} \mathrm{C}$ on glucose- (YPD) or glycerol-containing (YPG) media (A). Processing of yeast MrpL32 by human m-AAA proteases. Protein processing was analyzed in yta10 $\Delta y$ ta $12 \Delta$ cells harboring human m-AAA protease subunits (described in panel A) by SDS-PAGE and immunoblotting. Maturation of MrpL32 substrate was monitored in isolated mitochondria by immunoblotting using polyclonal antisera directed against MrpL32. As a loading control the outer membrane protein Tom20 was used. Expression of paraplegin and AFG3L2 in yeast was confirmed by immunoblotting (B). p, precursor; m, mature;

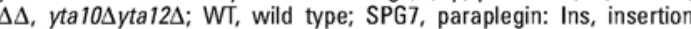
mutation (p.N739KfsX741).

Until now, studies have relied on in silico analysis, which can predict whether an identified sequence variant could be potentially deleterious [Brugman et al., 2008; Elleuch et al., 2006]. The only means that was applied to ascertain the causativeness of an identified sequence variants in SPG7 gene was through genetic association with the disease [Brugman et al., 2008; Elleuch et al. 2006].

In this study, we demonstrate that a yeast complementation assay can be used to determine the functional consequence of any identified sequence variants in the SPG7 gene. Previous studies have shown that human paraplegin together with AFG3L2 can functionally restore the $m$-AAA protease activity in yeast cells lacking the endogenous protease, thus demonstrating the functional preservation between human and yeast $m$-AAA proteases [Atorino et al., 2003]. To evaluate the activity of paraplegin mutants (p.G349S, p.W583C, p.A510V, and p.N739KfsX741; outlined in Supp. Fig. S3) identified in our study, we coexpressed proteolytically inactive $\mathrm{AFG} 3 \mathrm{~L} 2^{\mathrm{E} 575 \mathrm{Q}}$ or the ATPase mutant AFG3L $2^{\mathrm{K} 354 \mathrm{~A}}$ 


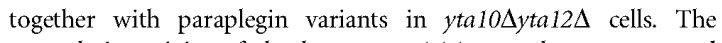
proteolytic activity of the human $m$-AAA complex was assessed

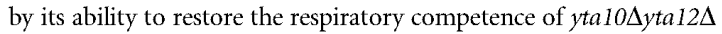
cells and proteolytic cleavage of the substrate protein Mrpl32 (precursor) into the mature form. This complementation assay allows to assess the functional activity of paraplegin variants and to distinguish silent polymorphisms (p.T503A and p.R688Q) from pathogenic mutations (p.G349S, p.W583C, p.A510V, and p.N739KfsX741).

Moreover, the complementation assay provides evidence of whether the proteolytic activity of paraplegin, its ATPase activity, or both are affected by the mutations (Fig. 3C). Mutations that impair the ATPase activity of paraplegin allows only complementation, if the mutant paraplegin subunits assemble with AFG3L2 subunits, which are proteolytically inactive (due to a mutation in the proteolytic site) but exert ATPase activity. In contrast, mutations that abolish the proteolytic activity of paraplegin do not allow complementation, even if the mutant paraplegin subunits assemble with mutant AFG3L2 subunits with impaired ATPase activity suggesting mutation in the proteolytic domain likely affects the ATPase activity of the paraplegin subunit. However, one exception is noteworthy: mutations in the Walker B motif of paraplegin, which allow ATP-binding but abolish ATPhydrolysis, exert a dominant negative effect on other subunits within the assembled $m$-AAA complex. Therefore, the respiratory

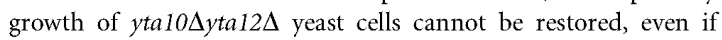
these mutant paraplegin variants are coexpressed with wild-type AFG3L2 [Augustin et al., 2009].

Our findings using the yeast complementation assay on the newly identified SPG7 variants validate predictions made by Polyphen and SIFT programs, highlighting the effectiveness of an in silico analysis. Moreover, the experimental results of our assay provide additional information on enzymatic activities of the mutant $m$-AAA complexes, which may be relevant clinically and will assist in the interpretation of genetic data in SPG7 diagnosis.

\section{Acknowledgments}

The authors thank the HSP patients/families for their participation in this study, and B. Brandt and A. Shostak for their assistance in the mutational screen. This work was funded partly by the Deutsche Forschungsgemeinschaft and by institutional internal fund to A.U.M. and by grants of the Deutsche Forschungsgemeinschaft, the European Research Council and the German-Israeli-Project (DIP grant F.5.1.) to T.L.

\section{References}

Arlt H, Steglich G, Perryman R, Guiard B, Neupert W, Langer T. 1998. The formation of respiratory chain complexes in mitochondria is under the proteolytic control of the $m$-AAA protease. EMBO J 17:4837-4847.

Arlt H, Tauer R, Feldmann H, Neupert W, Langer T. 1996. The YTA10-12 complex, an AAA protease with chaperone-like activity in the inner membrane of mitochondria. Cell 85:875-885.
Arnoldi A, Tonelli A, Crippa F, Villani G, Pacelli C, Sironi M, Pozzoli U, D’Angelo MG, Meola G, Martinuzzi A Crimella C, Redaelli F, Panzeri C Renieri A, Comi GP, Turconi AC, Bresolin N, Bassi MT. 2008. A clinical, genetic, and biochemical characterization of SPG7 mutations in a large cohort of patients with hereditary spastic paraplegia. Hum Mutat 29:522-531.

Atorino L, Silvestri I Koppen M, Cassina L, Ballabio A, Marconi R, Langer T, Casari G. 2003. Loss of $m$-AAA protease in mitochondria causes complex I deficiency and increased sensitivity to oxidative stress in hereditary spastic paraplegia. J Cell Biol 163:777-787.

Augustin S, Gerdes F, Lee S, Tsai FT, Langer T, Tatsuta T. 2009. An intersubunit signaling network coordinates ATP hydrolysis by $m$-AAA proteases. Mol Cell 35:574-585.

Brugman F, Scheffer H, Wokke JH, Nillesen WM, de Visser M, Aronica E, Veldink JH, van den Berg LH. 2008. Paraplegin mutations in sporadic adult-onset upper motor neuron syndromes. Neurology 71:1500-1505.

Casari G, De Fusco M, Ciarmatori S, Zeviani M, Mora M, Fernandez $P$ De Michele G, Filla A, Cocozza S, Marconi R Dürr A, Fontaine B, Ballabio A. 1998. Spastic paraplegia and OXPHOS impairment caused by mutations in paraplegin, a nuclear-encoded mitochondrial metalloprotease. Cell 93:973-983.

Depienne C, Stevanin G, Brice A, Durr A. 2007. Hereditary spastic paraplegias: an update. Curr Opin Neurol 20:674-680.

Elleuch N, Depienne C, Benomar A, Hernandez AM, Ferrer X, Fontaine B, Grid D, Tallaksen CM, Zemmouri R, Stevanin G Durr A, Brice A. 2006. Mutation analysis of the paraplegin gene (SPG7) in patients with hereditary spastic paraplegia. Neurology 66:654 659 .

Harding AE. 1983. Classification of the hereditary ataxias and paraplegias. Lancet 1:1151-1155.

Koppen M, Bonn F, Ehses S, Langer T. 2009. Autocatalytic processing of m-AAA protease subunits in mitochondria. Mol Biol Cell 20:4216 4224.

Koppen M, Metodiev MD, Casari G, Rugarli EI, Langer T. 2007. Variable and tissuespecific subunit composition of mitochondrial $m$-AAA protease complexes linked to hereditary spastic paraplegia. Mol Cell Biol 27:758-767.

Langer T. 2000. AAA proteases: cellular machines for degrading membrane proteins. Trends Biochem Sci 25:247-251.

Leonhard K, Guiard B, Pellecchia G, Tzagoloff A, Neupert W, Langer T. 2000. Membrane protein degradation by AAA proteases in mitochondria: extraction of substrates from either membrane surface. Mol Cell 5:629-638.

McDermott CJ, Dayaratne RK, Tomkins I, Lusher ME, Lindsey IC, Johnson MA Casari G, Turnbull DM, Bushby K, Shaw PJ. 2001. Paraplegin gene analysis in hereditary spastic paraparesis (HSP) pedigrees in northeast England. Neurology 56:467-471.

Ng PC, Henikoff S. 2003. SIFT: predicting amino acid changes that affect protein function. Nucleic Acids Res 31:3812-3814.

Nolden M, Ehses S, Koppen M, Bernacchia A, Rugarli EI, Langer T. 2005. The m-AAA protease defective in hereditary spastic paraplegia controls ribosome assembly in mitochondria. Cell 123:277-289.

Nolden M, Kisters-Woike B, Langer T, Graef M. 2006. Quality control of proteins in the mitochondrion. Top Curr Genet 16:119-147.

Ramensky V, Bork P, Sunyaev S. 2002. Human non-synonymous SNPs: server and survey. Nucleic Acids Res 30:3894-3900.

Rugarli EI, Langer T. 2006. Translating m-AAA protease function in mitochondria to hereditary spastic paraplegia. Trends Mol Med 12:262-269.

Tatsuta T, Langer T. 2009 AAA proteases in mitochondria: diverse functions of membrane-bound proteolytic machines. Res Microbiol 160:711-717.

Tzoulis C, Denora PS, Santorelli FM, Bindoff LA. 2008. Hereditary spastic paraplegia caused by the novel mutation 1047insC in the SPG7 gene. J Neurol 255: $1142-1144$.

Warnecke T, Duning T, Schwan A, Lohmann H, Epplen JT, Young P. 2007. A novel form of autosomal recessive hereditary spastic paraplegia caused by a new SPG7 mutation. Neurology 69:368-375.

Wilkinson PA, Crosby AH, Turner C, Bradley LJ, Ginsberg L, Wood NW, Schapira $\mathrm{AH}$, Warner TT 2004. A clinical, genetic and biochemical study of SPG7 mutations in hereditary spastic paraplegia. Brain 127(Pt 5):973-980. 


\section{Supporting Information}

\section{Clinical information}

In the HSP 28142 family with SPG7 mutations, the index patient (II-5, Fig.1) noticed gait problems at the age of 38 years. Now at the age of 42 years, he suffers from spasticity and paresis of the lower limbs. The maximum walking distance is about 300-400 meters and the patient requires walking assistance. The upper limbs are not affected. Sensibility and vibration sense are normal. In addition, the patient suffers from a mild bladder disturbance. Neurological examination showed a bilateral proximal paresis of the lower limbs with hyperreflexia and positive bilateral Babinski sign. The MRI imaging did not detect any gross abnormalities. A sister (II-2 Fig.1) of the index patient realized gait problems at the age of 36 years. She shows similar symptoms as the index patient. She also has a sustained ankle clonus. A cranial MRI analysis revealed a slight cerebellar atrophy. Three other siblings are asymptomatic.

\section{In silico analysis for prediction of pathogenicity}

To determine whether any non-synonymous sequence variant could be deleterious or pathogenic to the function of paraplegin, we used SIFT (Sorting of Intolerant From Tolerant) tool at http:/sift.jcvi.org/ and PolyPhen (Polymorphism Phenotyping) program at http:/genetics.bwh.harvard.edu/pph/. The SIFT tool predicts whether an amino acid substitution affects protein function based on sequence conservation at the site of the substitution and the biophysical properties of the exchanged amino acids (Ramensky, et al., 2002). PolyPhen is an algorithm, which calculates a possible impact of an amino acid substitution on the structure and function of the protein using physical and comparative considerations ( $\mathrm{Ng}$ and Henikoff, 2003).

\section{Cloning Procedures}

The human $A F G 3 L 2$ gene derived from the plasmid YEplac1 12ADHI-YTA1O(1-61)$A F G 3 L 2$ (36-798)-Myc (Koppen, et al., 2007) was cloned as an Xbal/HindIII-DNA fragment into the vector YCplac22ADHl YTA1O(1-61)-AFG3L2(36-798). The Myc-tag was deleted and a SalI site was introduced behind the stop codon. To increase the expression of $A F G 3 L 2, \sim 250$ bps of the 3 UTR of the YTA10 gene were amplified from the plasmid pGEM4-HIS3MX6-Gall-YTA10UTR and introduced downstream of $A F G 3 L 2$ by SalI and HindIII (Koppen, et al., 2009). For the expression of paraplegin, the 3 UTR fragment of the YTA10 gene was introduced downstream of paraplegin in the plasmid YEplac181-ADHl-YTA10(1-63)-paraplegin(59-795) (Koppen, et al., 2007 ) as described for $A F G 3 L 2$ (above).

\section{Site-Directed Mutagenesis of paraplegin and $A F G 3 L 2$}

Paraplegin and $A F G 3 L 2$ were mutagenized in the yeast expression constructs using the QuickChange( $\mathrm{XL}$ Site-Directed Mutagenesis Kit (Stratagene) and the following oligonucleotides: 5'-CAA AGG GCG CAC TGC TGC TCA GCC CCC CCG GCT GTG GGA AG-3' (forward primer) and 5'-CTT CCC ACA GCC GGG GGG GCT GAG CAG CAG TGC GCC CTT TG -3' (reverse primer) to introduce the glycine to serine mutation at position 349 in paraplegin; 5'-GCT GAC CCA GTC CAG CGC CTT TTA CTC CCA GC-3' (forward primer) 
and 5'-GCT GGG AGT AAA AGG CGC TGG ACT GGG TCA GC-3' (reverse primer) for T503A mutation in paraplegin; 5'-GCC ACG CCT TGG TGG GCT GCA TGC TGG AGC ACA CGG AG-3' (forward primer) and 5'-CTC CGT GTG CTC CAG CAT GCA GCC CAC CAA GGC GTG GC-3' (reverse primer) for W583C mutation in paraplegin; 5' CAT GGG CAT CGG GCA GCG CCC CTT CAG CC-3' (forward primer) and 5'-GGC TGA AGG GGC GCT GCC CGA TGC CCA TG-3' (reverse primer) for R688Q mutation in paraplegin; 5'-ACT CCC AGC GTC TGG TAG AGC TGA CAC CAG G-3' (forward primer) and 5'-CCT GGT GTC AGC TCT ACC AGA CGC TGG GAG T-3' (reverse primer) for A510V mutation in paraplegin; 5'-GGA AAA GGA AGT GAT AAA ACT ATG AGG ACA TTG AGG-3' (forward primer) and 5'-CCT CAA TGT CCT CAT AGT TTT ATC ACT TCC TTT TCC-3' (reverse primer) for insertion mutation in paraplegin ( $\mathrm{SPG} 7^{\mathrm{ins}}$ ).

In case of AFG3L2, glutamic acid 575 was exchanged by glutamine (Koppen, et al., 2007) and lysine 354 was exchanged by alanine mutating the respective codon (Augustin, et al., 2009). Mutagenesis was verified by DNA sequencing.

\section{Supp. References}

Augustin S, Gerdes F, Lee S, Tsai FT, Langer T, Tatsuta T. 2009. An intersubunit signaling network coordinates ATP hydrolysis by m-AAA proteases. Mol Cell 35(5):574-585.

Koppen M, Metodiev MD, Casari G, Rugarli EI, Langer T. 2007. Variable and tissue-specific subunit composition of mitochondrial m-AAA protease complexes linked to hereditary spastic paraplegia. Mol Cell Biol 27(2):758-767.

Koppen M, Bonn F, Ehses S, Langer T. 2009. Autocatalytic processing of m-AAA protease subunits in mitochondria. Mol Biol Cell 20(19): 4216-4224

Ng PC, Henikoff S. 2003. SIFT: Predicting amino acid changes that affect protein function. Nucleic Acids Res 31(13):3812-3814.

Ramensky V, Bork P, Sunyaev S. 2002. Human non-synonymous SNPs: server and survey. Nucleic Acids Res 30(17):3894-3900. 


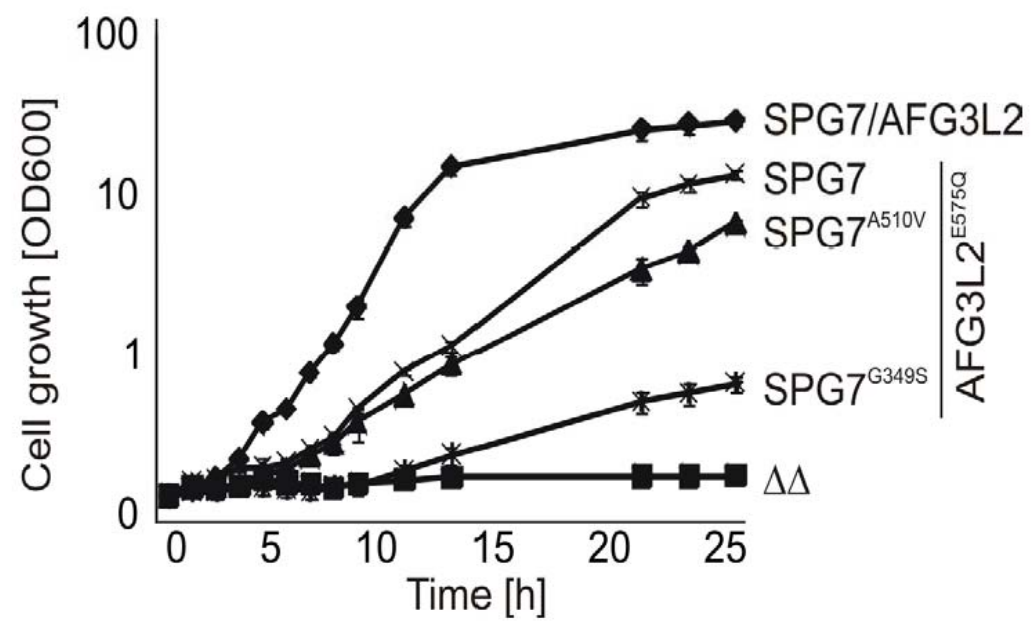

Supp. Figure S1. Respiratory growth of yta10 $\Delta y t a 12 \Delta$ cells expressing human $m$-AAA protease subunits. Paraplegin and mutant variants of paraplegin were co-expressed with AFG3L2 or $\mathrm{AFG} 3 \mathrm{~L} 2^{\mathrm{E} 575 \mathrm{Q}}$ in $y$ ta 10 $\Delta$ yta $12 \Delta$ cells. Cell growth was analyzed at $30^{\circ} \mathrm{C}$ in liquid glycerolcontaining (YPG) media and assessed at $\mathrm{OD}_{600}$ over the indicated time points. The data represent the mean standard \pm deviation of three independent experiments. $\Delta \Delta$, yta10 $\Delta y \operatorname{ta} 12 \Delta ; \mathrm{SPG} 7$, paraplegin.

Supp. Figure S2. Proteolytic activity of hetero-oligomeric $m$-AAA protease (paraplegin and AFG3L2) complexes in yeast. Respiratory growth of yta 10 4 ta 124 cells expressing human $m$ AAA protease subunits. To assess the activity of hetero-oligomeric complexes, the mutant variants; paraplegin ${ }^{\mathrm{T} 503 \mathrm{~A}}$, paraplegin ${ }^{\mathrm{R} 688 \mathrm{Q}}$ or paraplegin ${ }^{\mathrm{T} 503 \mathrm{~A} / 688 \mathrm{Q}}$ were co-expressed with AFG3L 2 or with AFG3L $2^{\mathrm{E} 5750}$ in yta104yta 124 cells. Cell growth was analyzed by growing at $30^{\circ} \mathrm{C}$ on glucose containing (YPD) or glycerol-containing (YPG) media to examine the respiratory competence of the cells (A). Processing of yeast MrpL32 by human m-AAA proteases. Protein processing was analyzed in yta 10 Ayta $12 \Delta$ cells harboring human $m$-AAA protease subunits (described in panel A) by SDS-PAGE and immunoblotting. Maturation of MrpL32 substrate was monitored in isolated mitochondria from yeast by immunoblotting using polyclonal antisera directed against the mature and the precursor form of MrpL32. As a loading control the outer membrane protein Tom20 was used, also expression of paraplegin and AFG3L2 in yeast was confimed by immunoblotting (B). p, precursor; $\mathrm{m}$, mature; $\Delta \Delta$, yta 10 4 yta $12 \Delta ; \mathrm{WT}$, wild type; SPG7, paraplegin. 


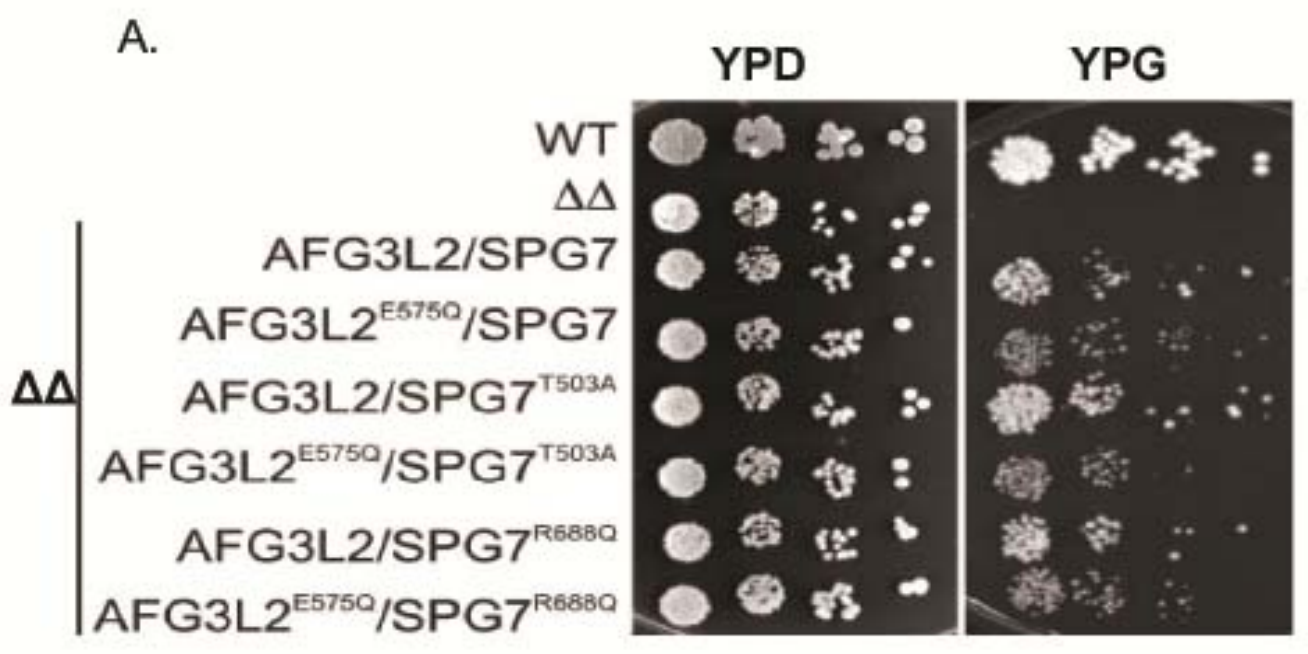

B.

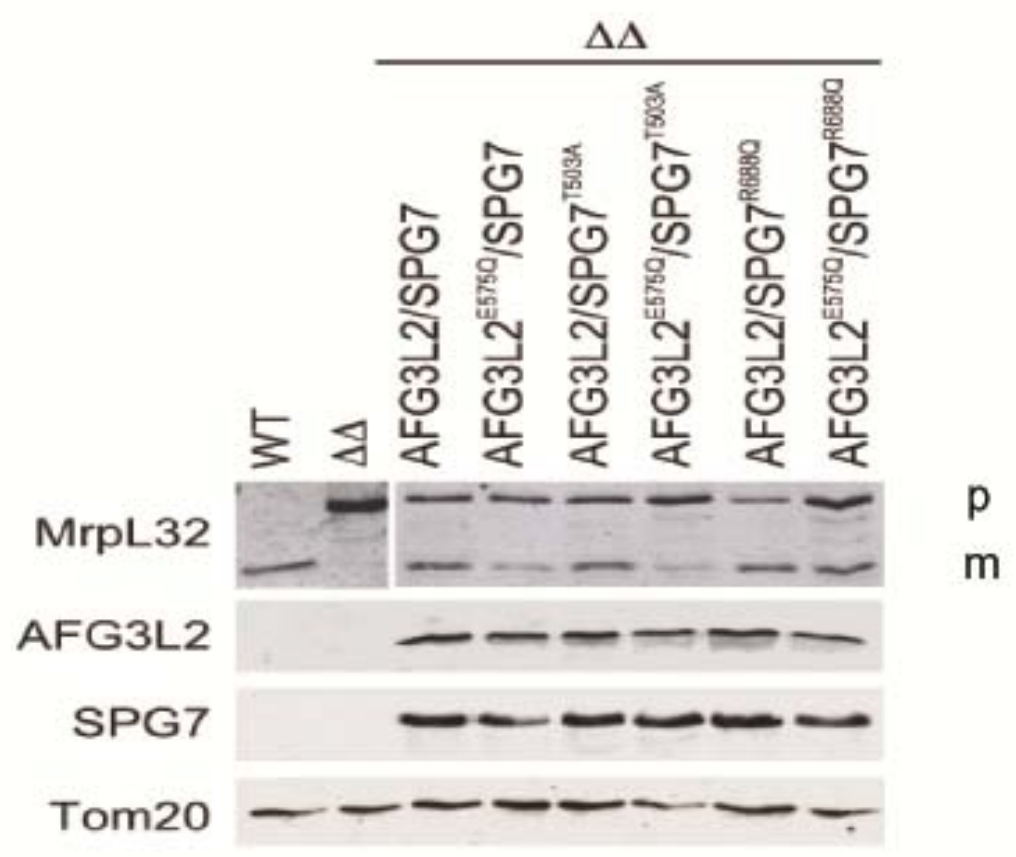




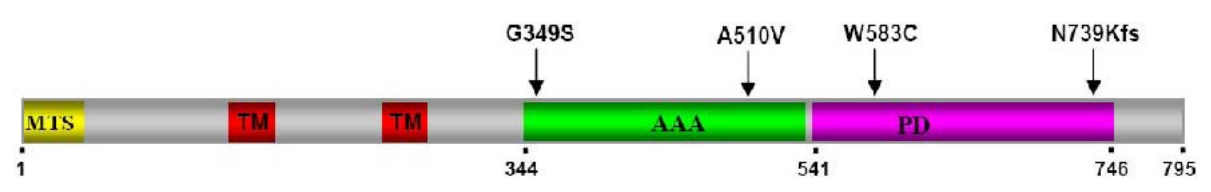

Supp. Figure S3. Schematic diagram outlining the structural domains of paraplegin protein with the location of the mutations, which were identified in the HSP cohort. MTS - Mitochondrial targeting sequence; TM - Transmembrane; AAA - ATPase Associated with various cellular Activities; PD - Proteolytic domain. 
Supp. Table S1. In silico prediction analysis of various $S P G 7$ missense sequence variants.

\begin{tabular}{|c|c|c|c|c|c|c|}
\hline Residue1 & Position & Resiue2 & refSNP ID & Allele & PolyPhen & SIFT \\
\hline \multicolumn{7}{|l|}{ Mutations } \\
\hline Gly & 349 & Ser & & G/A & Probably damaging & Deleterious \\
\hline Try & 583 & Cys & & $\mathrm{G} / \mathrm{C}$ & Possibly damaging & Deleterious \\
\hline Ala & 510 & Val & & $\mathrm{C} / \mathrm{T}$ & Probably damaging & Deleterious \\
\hline \multicolumn{7}{|c|}{ Sequence variants } \\
\hline Gly & 56 & Val & rs17356396 & $\mathrm{G} / \mathrm{T}$ & Possibly damaging & Deleterious \\
\hline Asp & 428 & Glu & rs12921797 & $\mathrm{C} / \mathrm{G}$ & Probably damaging & Not scored \\
\hline Thr & 503 & Ala & rs 2292954 & $\mathrm{C} / \mathrm{T}$ & Benign & Tolerated \\
\hline Thr & 600 & Ala & rs11559076 & $\mathrm{C} / \mathrm{T}$ & Benign & Deleterious \\
\hline Phe & 623 & Cys & rs17783943 & $\mathrm{G} / \mathrm{T}$ & Possibly damaging & Deleterious \\
\hline Ser & 645 & Thr & rs 2099104 & $\mathrm{~A} / \mathrm{T}$ & Unknown & Tolerated \\
\hline Arg & 688 & Gln & $\mathrm{rs} 12960$ & $\mathrm{~A} / \mathrm{G}$ & Benign & Tolerated \\
\hline Asn & 730 & Asp & rs35749032 & $\mathrm{A} / \mathrm{G}$ & Benign & Tolerated \\
\hline
\end{tabular}




\section{Die Publikationsliste}

Stand: November 2010

1) Shoukier M, Teske U, Weise A, Engel W, Argyriou L (2008): Characterization of five novel large deletions causing hereditary haemorrhagic telangiectasia. Clin Genet $\underline{73}, 320-330$

2) Argyriou L, Wirbelauer J, Dev A, Panchulidze I, Shoukier M, Teske U, Nayernia K (2008): A newborn with hereditary haemorrhagic telangiectasia and an unusually severe phenotype. Swiss Med Wkly $\underline{138}$, 432-436

3) Shoukier M, Neesen J, Sauter SM, Argyriou L, Doerwald N, Pantakani DV, Mannan AU (2009): Expansion of mutation spectrum, determination of mutation cluster regions and predictive structural classification of SPAST mutations in hereditary spastic paraplegia. Eur J Hum Genet 17, 187-194

4) Antal A, Chaieb L, Moliadze V, Monte-Silva K, Poreisz C, Thirugnanasambandam N, Nitsche MA, Shoukier M, Ludwig H, Paulus W (2010): Brain-derived neurotrophic factor (BDNF) gene polymorphisms shape cortical plasticity in humans. Brain Stimul $3,230-237$

5) Auber B, Burfeind P, Thiels C, Alsat EA, Shoukier M, Liehr T, Nelle H, Bartels I, Salinas-Riester G, Laccone F (2010): An unbalanced translocation resulting in a duplication of $\mathrm{Xq} 28$ causes a Rett syndrome-like phenotype in a female patient. Clin Genet $\underline{77}, 593-597$

6) Bonn F, Pantakani K, Shoukier M, Langer T, Mannan AU (2010): Functional evaluation of paraplegin mutations by a yeast complementation assay. Hum Mutat $\underline{31}, 617-621$

7) Klimpe S, Zibat A, Zechner U, Wellek B, Shoukier M, Sauter SM, Pantakani DV, Mannan AU (2010): Evaluating the effect of spastin splice mutations by quantitative allele-specific expression assay. Eur J Neurol

8) Lee JH, Jung $C$, Javadian-Elyaderani $P$, Schweyer S, Schutte D, Shoukier M, Karimi-Busheri F, Weinfeld M, Rasouli-Nia A, Hengstler JG et al. (2010): Pathways of proliferation and antiapoptosis driven in breast cancer stem cells by stem cell protein piwil2. Cancer Res $\underline{70}$, 4569-4579

9) Zirn B, Arning L, Bartels I, Shoukier M, Hoffjan S, Neubauer B, Hahn A (2010) Ring chromosome 22 and neurofibromatosis type II: proof of two hit model for the loss of the NF2 gene in the development of meningioma (Clin Genet, im Druck)

\section{Eingereichte Manuskripte}

1) Stettner G M, Höger C, Shoukier M, Brockmann K, Auber B (2010) FMR2 gene deletion as a cause of non-specific mental retardation and autistic behavior in two brothers (Manuskript eingereicht in Am J Med Genet Part A) 
2) Shoukier M, Wickert J, SchröderJ, Bartels I, Auber B, Zoll b, Salinas-Riester G,Zirn B, Weise D,Brockmann K, Burfeind P (2010) A novel 4.7 Mb de novo deletion of chromosome $16 q 12.1 q 12.2$ in a child with dysmorphic features and profound mental retardation (Manuskript eingereicht in Am J Med Genet Part A) 


\section{Lebenslauf}

Ich wurde am 09.11.1976 als erstes Kind von Abed Shoukier und Makbula Nafaa in Souieda / Syrien geboren.

Von 1982 bis 1994 besuchte ich die Grundschule, Sekundarschule und anschließend das Gymnasium in Al-Quraia in Syrien. 1994 legte ich mein Abitur ab. Von 1994 bis 2000 studierte ich Humanmedizin an der Universität Damaskus in Syrien. Im Juli 2000 beendete ich mein Studium mit dem Staatsexamen. In den Jahren 2000 bis 2004 absolvierte ich meine Facharztausbildung in Gynäkologie und Geburtshilfe an der Frauenklinik des Universitätsklinikums in Damaskus, welche ich mit einer wissenschaftlichen Abschlussarbeit mit dem Titel "Geburtsstatistik und Sterberate der Mütter und der Kinder in der Frauenklinik des Universitätsklinikums in Damaskus“ abschloss. Nach der Anerkennung als Facharzt in Syrien habe ich als Arzt für Geburtshilfe und Gynäkologie ein Jahr lang am Younes Hospital, Damaskus, gearbeitet. Im Jahr 2005 habe ich ein Stipendium des Ministeriums für Hochschulwesen in Syrien bekommen und seit September 2005 bin ich am Institut für Humangenetik in Göttingen als wissenschaftlicher Mitarbeiter und Assistenzarzt in der Weiterbildung zum Facharzt für Humangenetik tätig.

Seit Mai 2009 bin ich mit Jihan Azloul verheiratet. 


\section{Danksagung}

Einen besonderen Dank möchte ich Herrn Prof. Dr. med. Dr. h. c. Wolfgang Engel aussprechen. Mein besonderer Dank gilt dabei seiner vorbildlichen fachlichen Betreuung in der nun 5 Jahre währenden Zusammenarbeit. Mit seiner unermüdlichen Unterstützung hat er wesentlich zum Gelingen dieser Arbeit beigetragen.

Des Weiteren danke ich Herrn Prof. Dr. rer. nat. Peter Burfeind, Leiter der Arbeitsgruppe DNA-Diagnostik, für seine uneingeschränkte Hilfe sowie das kritische Durchsehen dieser Arbeit.

Großer Dank gilt außerdem Herrn Dr. Ashraf $U$ Mannan für seine freundliche Unterstützung. Wir durften im Rahmen der experimentellen Arbeiten mit verschiedenen Arbeitsgruppen außerhalb unseres Hauses kooperieren. Ich bedanke mich bei allen unseren Kooperationspartnern für die erfolgreiche und fruchtbare Zusammenarbeit. 